\title{
THE PLANS AND ASPIRATIONS OF TEENAGE STUDENTS IN SEMI-RURAL \\ TIMOR-LESTE
}

By

\begin{abstract}
Anna P. Mitchell
A 120-point thesis submitted to University of Wellington in partial fulfillment of the requirements for the degree of
\end{abstract}

\section{Master of Development Studies}

\author{
2020 \\ School of Geography, Environment and Earth Sciences
}




\begin{abstract}
While there is wide agreement that education supports development, there is also much scholarship to suggest that the potential benefits of education are only fully realised when education systems are well-adapted to local needs. Systems left by colonial administrations in newly independent developing countries, for instance, can impede the achievement of their development goals.
\end{abstract}

This project focused on the plans and aspirations of secondary school students in Ermera subdistrict, a semi-rural region of Timor-Leste, in order to explore the relationship between education and local livelihoods. Three case study communities in Ermera vila, Ponilala and Mirtutu were examined. Guided by the concept of the 'good life', I sought to reveal what students, parents and educators hope to get out of education and development. This enabled me to assess whether the schooling that students are receiving is supporting their future goals.

The methodology combined ethnographic observation with other qualitative and quantitative data collection. It comprised twenty-two weeks in-country: volunteering, and conducting surveys and interviews. The ensuing data analysis draws on education theory, alternative development theory, and decolonisation theory.

Overall I found that the secondary school curriculum is Western-oriented, and focused on getting students into university rather than on preparing them for the kinds of lives they are likely to lead. Students overwhelmingly aspire to university or vocational study, once they leave school. Conceptions of the good life in the three communities centre on social connectedness and opportunities for the next generation. While there is an evident disconnect between the content of available secondary education and local livelihood realities, there have been successful initiatives from within all three communities to expand education over the past twenty years to include local skills and epistemologies. An extension of these efforts to create a more diverse education, with the inclusion of agriculture as a learning topic, could give students the best chance of gaining secure work and leading comfortable lives in the future. 
This thesis is dedicated to my grandfather, Peter Macnicol, who passed away before its completion. I know you are proud of me.

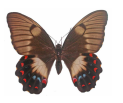




\section{Acknowledgements}

This thesis would not have been possible without the inspiration and support of many people. I sincerely thank:

The residents of Ermera vila, Ponilala and Mirtutu, for allowing me into your home, and for your kindness, generosity and enthusiasm.

My family, Mum, Dad and Pat, for your constant support, both during these past eighteen months and over the many years leading up to it. I could not have written this without you.

Stephen Ussery, who shaped the direction of this thesis, most importantly in site selection, and became a main source of support during my fieldwork.

Professor John Overton, my supervisor. Without your enthusiasm and encouragement I would not have completed this thesis.

Maria, for kindly letting me stay at your house in Dili.

Adé and Karolina, for keeping my mind and body together during the process.

To my friends from Wellington, Australia and Timor-Leste, including those who offered proof-reading help: Abbey, Bettie, Bird, Brandy, Chris, Jed, Jimmy, Kat, Konstantin, Níco, Ruohan, Sophie, Tiago, Tim, Tom, and others.

In particular, many thanks to:

Those who gave their assistance as translators:

Juvita Barros de Castro Nicolau Alves

Egidio Madeira

The two English teachers who helped and supported me throughout my stay:

Egidio Madeira Miguel Soares

The three families who looked after me during my time in Ermera subdistrict:

Lucia and Miguel Soares in Poetete;

Fernanda and Thomas da Silva in Mirtutu;

Tomasia and Egidio Madeira in Ponilala. 
The two directors who welcomed me, supported my research and took the time to share their thoughts with me:

Director Eduardo Martins

Amo Deonildo de Andrade

The students who shared their thoughts and aspirations, and were a pleasure to be around:

Ana Maria Da Silva

Estela João Martins

Inacio F. Martins

Joel Maria Soares dos Santos

Josélino de Jesus Soares

Juvita Barros de Castro
Maria Angela Das Neves Gago

Maria Antónia de Jesus

Melania Cipriano Martins

Nicolau A. Quintão

Vital Martins Babo

The parents who shared their views with me:

Ama Ana Maria

Xefi aldeia Carlos Ximines Babo

Mr Felix De Jesus Martins

Ilidio Babo

Inês Madeira Martins
João Fatima Martins

Manuel Alves Quintão

Teresa de Jesus Babo

Thomas das Neves

The staff and students at Mau-Kruma and Imacon Schools. In particular to the Grade 12 students at both schools who took part in the surveys - some more than once! Best wishes for the future.

The many leaders and professionals who shared their knowledge:

Adelaide Lopes

Berta Antonieta Tilman

Dr. Siobhan McDonnell

FarmPro Pete

Helen Hill

Mana Bettie
Mr Felix in Dili

Mr Julio Soares Madeira

Señor Director-General Antoninho Pires

The xefi suku of Mirtutu

Tony Jurd

And to:

His Excellency Dr José Ramos Horta, for your kindness and generosity to me during my fieldwork. As a great architect of your nation's freedom you are very busy, but you always made time for me and took an interest in my wellbeing. 


\section{Ba komunidade ho familia sira iha postu administrativu Ermera:}

Ba komunidade Poetete, Ponilala no Mirtutu nia abitante; i ba familia tolu ne'ebe hela besik Ermera vila, maun Miguel no mana Lucia nia familia ne'ebe hela iha Poetete, maun Egidio no mana Tomasia nia familia ne'ebe hela iha Ponilala, no familia da Silva ne'ebe hela iha

\section{Mirtutu:}

Obrigada ba imi nia laran luak atu simu hau, no imi nia tulun mai hau, durante tempu tomak hau hela iha Ermera. Maske hau la hatene buat ida wainhira hau too iha ne'e uluk liu, maibe imi ajuda hau nafatin hanesan kolega, laos hanesan partisipante iha peskiza de'it. Ita koalia hamutuk, halimar hamutuk, servisu hamutuk, no hau aprende buat barak hosi imi. Iha tempu ida nee, se hau koalia, hatudu ka halo buat ne'ebe monu iha laran, ha'u husu deskulpa. Hau sei la haluha imi. 


\section{Table of Contents}

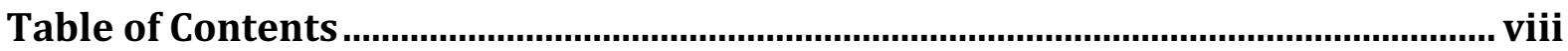

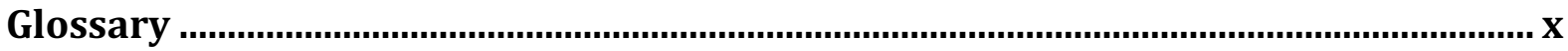

List of Acronyms

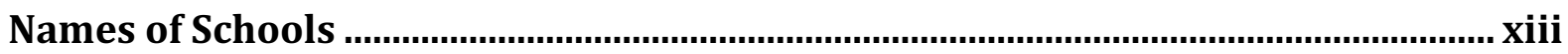

Foreword

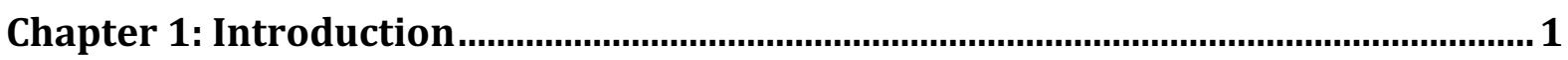

Chapter 2: Theories of Education and Development................................................... 5

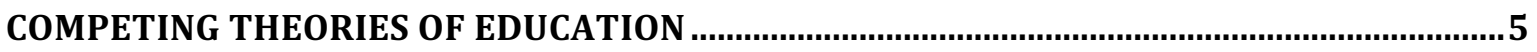

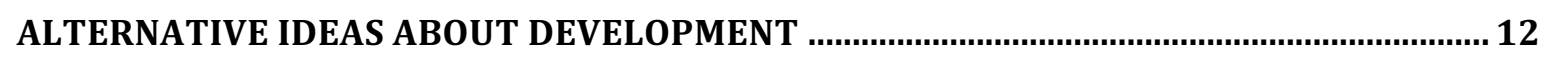

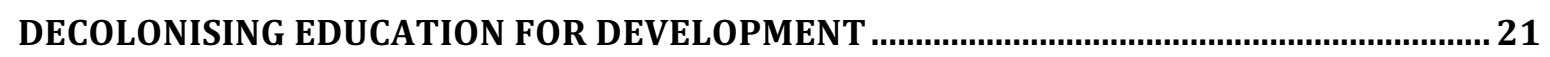

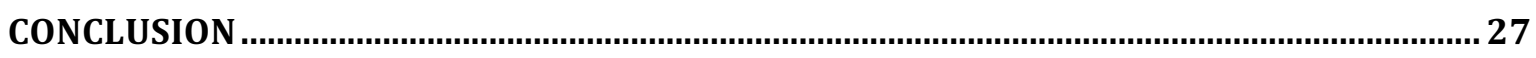

Chapter 3: Methodology and Methods........................................................................ 29

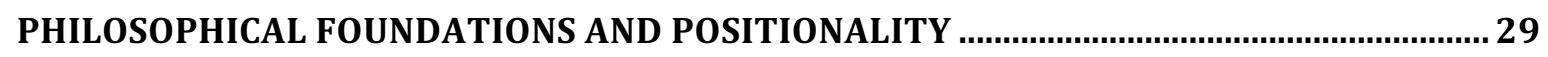

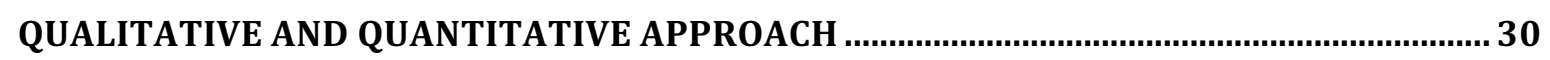

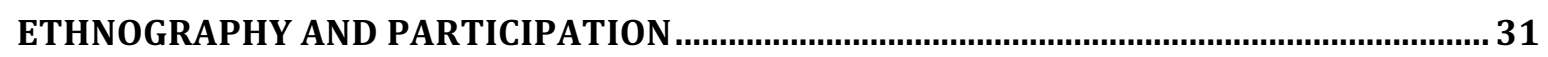

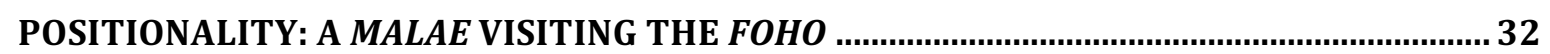

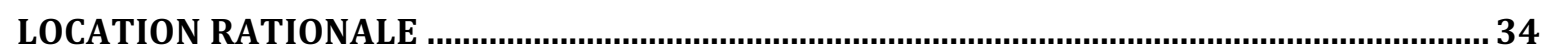

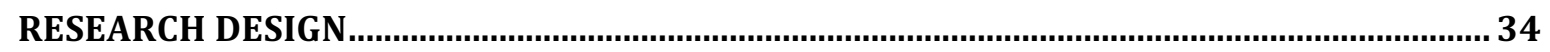

LIMITATIONS

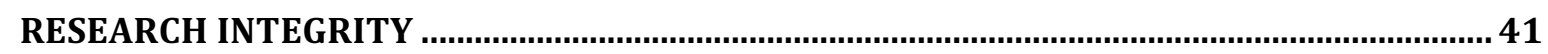

REFLECTION ON FIELDWORK AND METHODS: CONFRONTATIONAL CONTEXT .............. 43

CONCLUSION

Chapter 4: A Background to Education and Livelihoods in Timor-Leste................. 45

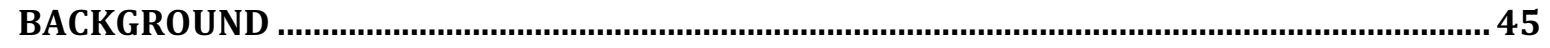

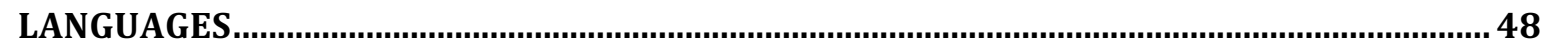

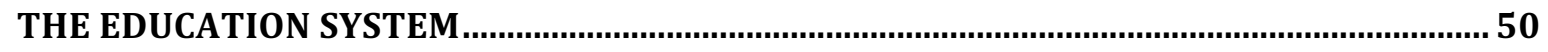

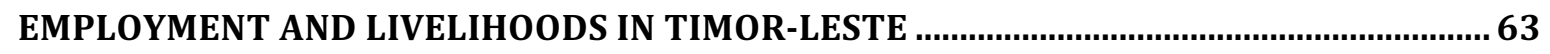

CONCLUSION

Chapter 5: Community and Family Life in Ermera Subdistrict ............................... 72

INTRODUCTION 


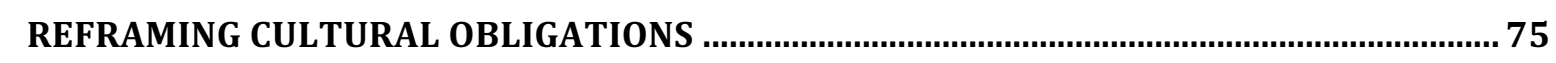

COMMUNITY EFFORTS TO BUILD SCHOOLS IN ERMERA SUBDISTRICT ……........................ 77

FAMILY AND COMMUNITY AS BOTH SUPPORT AND PRESSURE …….................................... 80

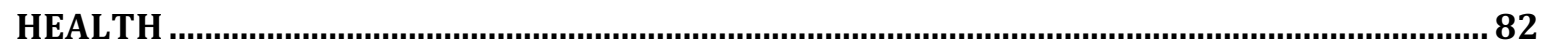

CONCLUSION

Chapter 6: Economy and Development

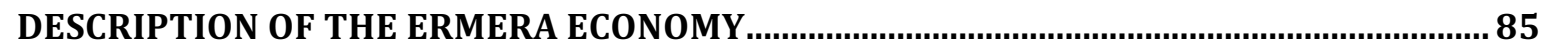

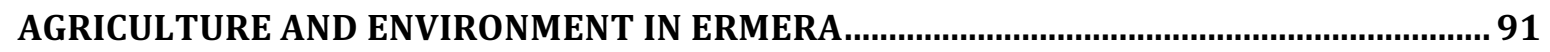

THE MEANING OF DEVELOPMENT FOR EDUCATION AND LIVELIHOODS …........................95

CONCLUSION

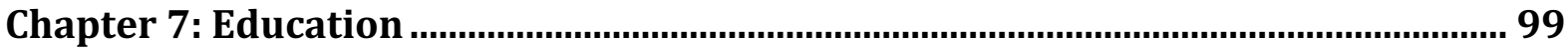

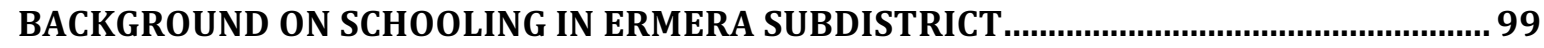

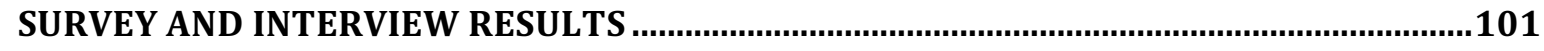

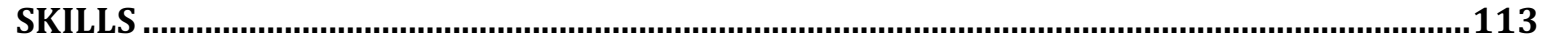

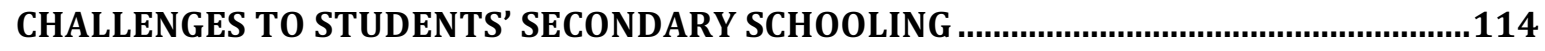

CONCLUSION

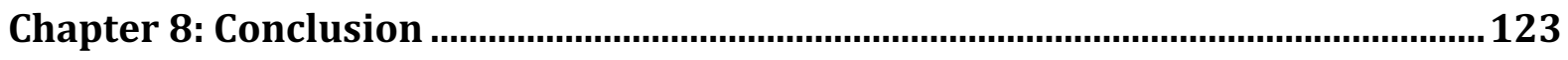

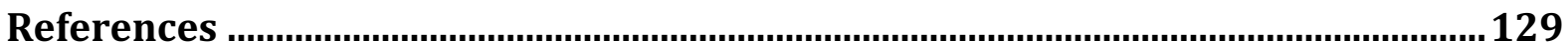

Appendix 1: Tetun chapter summaries.................................................................... 146

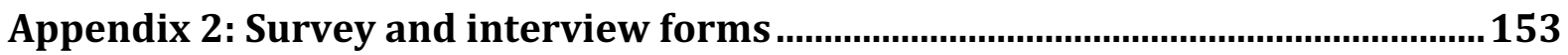

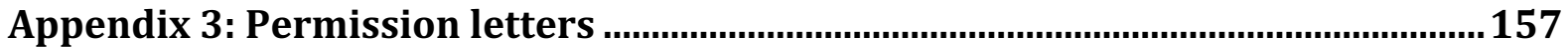

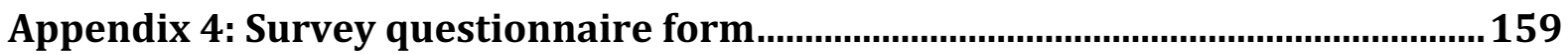

Appendix 5: Reference letters for student research assistants..............................160

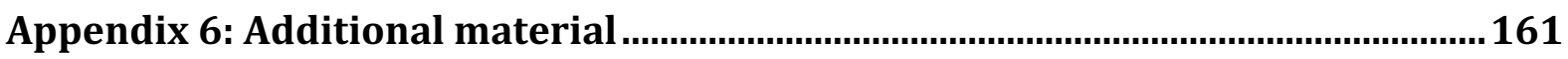

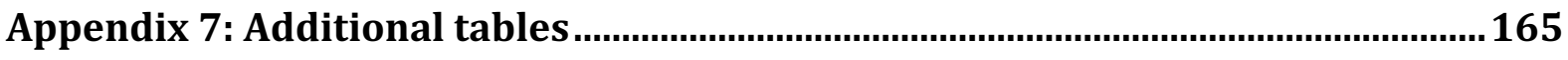

Appendix 8: Original passages of quoted interviews .............................................170 


\section{Glossary}

Ai-moruk

Aldeia

Amo

Buen vivir

Ekonomia

Ema kbiit la'ek

Ema kiik

Festa

Foin sa'e

Halimar

Joven / juventude

Kampu trabalhu

Kios

Kore metan

Kursu

Lia

Liurai

Malae

Mambae

Matenek
Traditional medicine

Sub-village

Honorific term for a priest; used interchangeably with 'Padre'. 'Good living' in Spanish; an umbrella term for a set of complex ideas, worldviews and indigenous knowledge which has gained prominence through social movements, scholarship and activist groups centred in the Andean region of Latin America.

Money; a family's financial means

Vulnerable people (very poor; elderly; widowed), lit.

'Powerless/disabled people'.

Ordinary folk, lit. 'little people'

Party

Teenager(s)

Play; relax; not have a job

Young people, particularly male, typically from age seventeen onwards, and still single.

A job; a place of work

Kiosk: small shop selling goods such as diesel fuel, oil, snacks, water, sweets and instant noodles.

A one-year funeral party

Course at a Higher Vocational Training Centre

Cultural events and ceremonies, especially to do with life and death, including weddings, dowry meetings, various funeral ceremonies, baptisms, dances, and observances at sacred houses and at the graves of deceased family members.

King; leader; the feudal kings of pre-colonial and colonial TimorLeste.

Foreigner: a respectful rather than pejorative term.

A major local language spoken in seven districts, including Ermera.

Intelligence, knowledge, skill, learning; a rather ambiguous word due to the breadth of related concepts that it may refer to. 
Microlet

Motór

Munisipiu

Postu administrativu

Suku

Superme

Tais

Tek vok

Tetun

Timor oan

Uma lulik

Vila

Xefi aldeia

Xefi suku
Minibuses providing public transport that operate within Dili and between regional centres.

Motorcycle; includes scooters

District; municipality

Subdistrict

Village

Cheap packaged noodles imported from Indonesia

Traditional cloth weaved by Timorese women

A technical-vocational school or institute

The lingua franca of Timor-Leste

'Child of Timor'; Timorese citizen(s)

Sacred house

Town

Sub-village chief

Village chief; local leader of a suku

\section{List of Acronyms}

DEF The Diverse Economies Framework proposed by J. K. Gibson-Graham.

DIT Dili Institute of Technology

ESTV Secondary Technical and Vocational Schooling (Portuguese: Ensino Secondário Técnico-Vocational)

$\mathrm{ETCl} \quad$ East Timor Coffee Institute

FRETELIN The Revolutionary Front for an Independent East Timor (Portuguese: Frente Revolucionária de Timor-Leste Independente)

GMN 'Grupo Média Nacional': a major media site in Timor-Leste

GSE General Secondary Education (Portuguese: Ensino Secondário Geral)

INFORDEPE National Institute for Training of Teachers and Education Professionals (Tetun: Institutu Nasionál ba Formasaun Dosente no Profisionál Edukasaun) 
INTERFET The International Force East Timor, the Australia-led multinational peacemaking taskforce.

IOB Institute of Business

MDGs Millennium Development Goals

MoE The Ministry of Education in Timor-Leste (Portuguese: Ministério da Educação)

NGO Non-governmental organisation

PERMATIL The Permaculture Organisation in Timor-Leste

RDTL The independent government of Timor-Leste which was formally reinstated in 2002 (Tetun: Republika Demokrátika Timor-Leste)

RSE The Recognised Seasonal Employer scheme run by the New Zealand Government.

SD, SMP, SMA 'Sekolah Dasar', 'Sekolah Menengah Pertama' and 'Sekolah Menengah Atas': Indonesian terms for primary, junior high school and senior high school levels respectively.

SDGs Sustainable Development Goals

SOLS Science of Life Systems 24/7: English language training centres in TimorLeste. Recently rebranded as AHHA Education.

SWP

The Seasonal Worker Program of the Australian Government

UN United Nations

UNDIL Universidade de Dili

UNITAL Universidade Oriental Timor Lorosa'e

UNPAZ Universidade da Paz

UNTAET The United Nations Transitional Administration in East Timor

UNTL The public university of Timor-Leste, located in Dili (Portuguese:

Universidade Nacional Timor-Lorosa'e). 


\section{Names of Schools}

20 de Agosto School

Imacon School

Mau-Kruma School

NCES

Padre Hilario School
Escola Pre-secundária 20 de Agosto Ermera': the public presecondary school in Ermera vila.

'Escola Secundária Catholica Maria Immaculada Conceição Ermera': the private Catholic secondary school in Ermera vila.

'Escola Secundária Gerál Helio Sanches Pina Mau-Kruma Ermera': the public senior secondary school in Ermera vila.

'Escola Nino Konis Santana de Gleno': the large public senior secondary school in Gleno, Ermera district.

'Escola Catholica Pre-secundária Padre Hilário Madeira

Ponilala': the Catholic pre-secondary school of Ponilala. 


\section{Foreword}

\section{Have you ever seen the rain?}

Someone told me long ago

There's a calm before the storm

I know, it's been comin' for some time

When it's over, so they say

It'll rain a sunny day

I know, shinin' down like water

I want to know, have you ever seen the rain?

I want to know, have you ever seen the rain?

Comin' down on a sunny day...

The most distinctive memory I have of my time doing fieldwork in Ermera subdistrict is of walking back to Ermera town with a group of teenage boys through the deepening twilight. After I had helped to teach at a free English course in Ponilala village, which was about an hour's walk from Ermera town, around five of the male students would walk the five kilometre stretch with me as a kind of protection. It was not considered acceptable for girls and women to walk alone, and as a female malae ${ }^{1}$ I was vulnerable, so the boys would walk a just under two-hour round trip to practice their English, keep me company, and keep me safe.

A couple of the boys told me that their favourite hobby was singing. 'You know Rod Stewart? He's the best!' One began to sing Have You Ever Seen the Rain, and several others joined in enthusiastically. As an Australian, who grew up in a culture where it is often seen as very embarrassing for boys to sing, especially off the bat, this was delightful. They told me that sometime in previous years another malae had come to volunteer as a teacher at the course. He had taught the students different English songs, accompanying them on his guitar.

\footnotetext{
${ }^{1}$ Foreigner.
} 
It was one of the most uplifting moments of the time I spent in Ermera district, and it continues to remind me of the garrulousness of the teenagers I crossed paths with, along with their openness to, and enthusiastic wish to engage with, strangers such as myself.

The song has taken on a growing significance to my relationship with Ermera subdistrict, both while I stayed there and after I left, and to what its residents continue to teach me. These young adults and their families face daily impediments to their wellbeing, and access to vital services, educational opportunities, and gainful work. Despite this, the first thing I noticed when arriving in Ermera sub-district was the sunny disposition of those living and working there, particularly the laughter and supportiveness among teenage secondary school students, and the hospitality to myself, a stranger stumbling around making a steady stream of faux pas and speaking bad Tetun. Seeing the sunshine through the rain and cold is an ability that is valued everywhere. In development work it sets an excellent example of looking forward and focusing on the positives while still acknowledging the challenges, failures and looming clouds on the horizon.

Beyond the rain lies a sunny day. 


\section{Chapter 1: Introduction}

Education is the subject of much discussion and many projects at all levels of society, from the grassroots level to the level of government. There is wide agreement that education is important for both individual wellbeing and community development (McGrath, 2018; Overton, et. al. 2020; McCowan and Unterhalter, 2015). People across the world seek educational opportunities as part of their aspirations for the kind of work they want to do, the kind of life they want to live, and the kind of person they want to become.

Education can increase a person's ability to engage with the world around them and give them a greater degree of power and autonomy. Gaining literacy and numeracy can enable an individual to participate on a more equal footing in their community and the wider economy (Sen, 1999). In an increasingly interconnected world education has become crucial and it is why it is now viewed as a basic human right (McGrath, 2018).

Countless people across the world in 'developed' and 'developing' countries alike seek educational opportunities and undertake further education for a variety of reasons. Some wish to gain the skills necessary to expand their employment prospects, or obtain the kind of work they want to do for a living. Education can offer a way out of poverty and the myriad disadvantages that often come with it, such as ill-health, gender-based inequality, disenfranchisement and oppression (Freire, 1972; Sen, 1999). Others wish to increase their understanding of the world around them, or develop on a personal level. For still others it might be a status symbol, marking their identity as an erudite citizen of the world. It might be a combination of these reasons. Education can offer hope and the ability, through the expansion of capabilities and understanding of the wider world, for a person to realise their full potential, obtain greater freedom, choice, confidence, and critical engagement within their social context. This engagement by an individual can have a flow-on effect to others. Education has shared public benefits as it can facilitate people achieving social change, and improve public health, social security, and increase women's freedom and economic participation, which itself produces a range of positive development outcomes (Sen, 1999; Gibson 1999; Chant and Sweetman, 2012; Masuda and Yamauchi, 2018). 
However, the degree to which education can enable these positive outcomes depends upon its suitability to a given locality. Education systems left by colonising countries generally do not reflect the language, livelihoods, or daily realities of students and communities living in newly independent states, and this can impede these states in achieving their development goals. Development and education theorists (including Coxon, 2020; Escobar, 1995; Fleming, 2015; Freire, 1972, Hill, 2007; Hill, 2016; Hill, 2017; Overton et. al., 2020; Vulliamy, 1981) continue to call for education to be shaped by and reflect local priorities and needs so that it can facilitate desired individual and social outcomes.

While the issue of education is strongly linked to conceptions and strategies for development, the connection between education and development and the meaning of both concepts has not been explored closely. What type of education is being referred to, and what is meant by 'development'? Some theorists (Bulloch, 2014; Fleming, 2015; Overton et. al., 2020) have explored these questions, but the two terms have largely remained unscrutinized.

It is safe to assume that the question of what type of development is desired, and what sort of education is needed to achieve that type of development might be answered differently in different places. It follows that more locally-based studies are needed if we are to better understand the relationship between education and development. Such an improved understanding might enable us to improve the outcomes of both.

This research examines the future plans and aspirations of teenage students attending school in Ermera subdistrict, a coffee-growing region of Timor-Leste. I focused on the experiences of secondary school students in order to explore the interplay between secondary education and livelihoods, and specifically whether secondary school students' education is appropriate for what they want to do after they finish school.

In order to shed light on this question I conducted surveys and interviews with teenage students to gauge their views on education and their aspirations for the future. I asked students what their favourite subjects were, and I sought to get an idea of the challenges they faced day-to-day. Increasingly I tried to get a sense of the context within which they 
were growing up, what their life was like, and what they wanted, not just for future work and study, but in a general sense, what they envisaged as a good life. I also asked the parents of teenage students for their thoughts on education and what they wanted for their children's future. I asked teachers and school principals for their views on education, and their observations on education and livelihoods in Ermera subdistrict and beyond.

I began to perceive that the interconnectedness of teenagers and their families meant that their idea of the good life was socially oriented, and included both elements of nationalistic development rhetoric oriented towards modernization and a strong impetus to looking after and improving community members' wellbeing. It became important to frame the question in this way: what good life do people envisage as the ideal result of development?

My thesis poses a number of primary and secondary questions to do with secondary school education and livelihoods. Centrally it seeks to answer:

What type of secondary education is appropriate for the livelihood conditions and aspirations of Timor-Leste?

Secondary to this main question are a set of sub-questions which provide context, and enable the primary question to be answered:

1. What do students and their parents view as a 'good life'?

2. How do teenage students, as well as their parents, view the education that they are receiving?

3. How does senior secondary schooling in Ermera subdistrict contribute to local livelihoods?

4. What do secondary school students aged sixteen and upwards want to do in the future and what types of education might suit these aspirations best? 
In Chapter Two I will cover the relevant literature on education, livelihoods, human capital, theory on decolonising education and alternative ideas of development.

Chapter Three will describe the philosophical foundations of this research, the methods used, the position from which it is written, and key issues arising from the research process, including the ethical considerations.

Chapter Four will give a brief overview of Timor-Leste, its education system and economy, and consider the complexity of education and livelihoods within the country.

Chapter Five will present findings of the interviews and surveys specific to community life in Ermera subdistrict; covering the push for education among the three communities I spent time in; the significance of cultural obligations to livelihoods and education; and a sketch of what a 'good life' might be, based on this picture.

Chapter Six will focus on students' aspirations within the context of jobs available in Ermera and further afield, the nature of the local economy, and the centrality of agriculture within residents' lives, which depends heavily upon the natural environment.

In Chapter Seven I will set out the results of the student interviews and surveys in detail, as well as broader strengths and challenges within schooling based on interviews with parents, educators and professionals further afield.

I will present my final conclusions and reflections in Chapter Eight, and consider where the findings from the research leave us. 


\section{Chapter 2: Theories of Education and Development}

Education is generally understood to be an important enabler of development, and it is the subject of numerous international agreements. This chapter will provide an overview of the literature on education within development discourse, where it is often viewed as a way to expand human capital which in turn promotes economic growth, although education is also embedded in other forms of capital. The work of Amartya Sen and Paulo Freire, two seminal theorists working across the education and development disciplines, will be compared. Freire's work has influenced a radical approach to education and development, along with the work of educational theorists Ivan Illich and Everett Reimer. The chapter will then explore alternative models of development, which are part of a post-development shift within development theory: recent work has turned away from conventional Western capitalist models of development and towards other approaches, such ideas centred on wellbeing and the environment. Partner theorists J. K. Gibson-Graham (2005) have recognised and explored different ways of living, and other economic realities than those captured by classic economic theory. They support place-based approaches to education for development. Lastly, the chapter will consider the literature on decolonising education, which correlates with post-development theory and alternative models of development, and conclude that, with a few exceptions, the three bodies of knowledge have not yet been linked up within development-related research.

\section{COMPETING THEORIES OF EDUCATION}

\section{EDUCATION IN GLOBAL DEVELOPMENT DISCOURSE}

There is wide agreement in the academic sphere that education is important for development. Education is generally agreed to be an objective, a way toward, and a driver of development (McCowan and Unterhalter, 2015). At its best, education is seen to increase human capital by equipping people with the skills needed to gain employment, create innovation, and gain an understanding of their wider world, increasing their sense of agency, their freedom of choice, and their ability to exercise their rights (McGrath, 2018). Influential research has found that education, particularly girls' education, has a range of 
positive impacts, concluding that it is a path to achieving economic, health and social development goals (Summers, 1992; UNICEF, 2004, 2011).

Education features prominently in numerous global agreements on development. The foremost of these are the Millennium Development Goals (MDGs), and the more recent Sustainable Development Goals (SDGs) (2015-2030). The MDGs are part of a neostructural paradigm in which education is viewed as a human right rather than a mere commodity (Overton et. al., 2020). Others include the Education For All (EFA) Goals and the World Campaign for Education Now. The latter advocates for the expansion of primary education as a way to overcome poverty, and argues that governments should prioritize the universalization of primary education first, before investing in secondary education, and, after that, in higher education (Hill, 2005). International organisations continue to view education as a key concern for development and wellbeing worldwide. The post-2015 global development agenda has continued to emphasize access (i.e. increasing student enrolment) and formal education, although higher education has received greater attention in Sustainable Development Goal 4 ('Ensure inclusive and equitable quality education and promote lifelong learning opportunities for all') (McGrath, 2016; UNDP, 2020).

\section{EDUCATION TO INCREASE HUMAN CAPITAL}

Education is often seen as a way to increase human capital in order to stimulate economic growth. Human capital is an economic term mainly used to describe the skills and knowledge workers bring to the production of future goods and services (Welchman, 2000, p. 51). In the 1950s and 1960s, policy-makers in the Global North became convinced that continuing industrialization and modernization required investment in human capital. As the nation-building of many countries in the Global South was underway, many donor states and international partners pushed for the expansion of Western forms of schooling in these countries (McGrath, 2018). The prevailing capitalist view of the economy values formal activities over informal ones: the purpose of education is to produce a productive labour force for the formal economy to support economic expansion (Tickly, 2004). Education is therefore designed to prepare young people for formal jobs in urban settings (Fleming, 2015 p. i). Overton et. al. (2020), who expand on Datzberger's proposed continuum between assimilative and transformative forms of education (Datzberger, 2018, p. 126), explain that 
both neoliberal and retroliberal models of education for development aim to equip the workforce with skills to drive economic growth.

\section{EDUCATION AND OTHER TYPES OF CAPITAL}

Education also depends on natural capital, and is a key component of social capital. The capacity of a given individual to expand their human capital (comprising their knowledge, skills, and abilities), depends upon the world's natural resources, which sustain human life on earth. Ecological systems and the 'natural capital stocks' which produce them contribute both directly and indirectly to human welfare (Constanza et. al. 1997). While Western theories of development typically take the vital resources of the natural world for granted, they have a more prominent place within alternative approaches to development, which are covered later on in this chapter. In turn, education holds a prominent place within Pierre Bourdieu's conception of social and cultural capital, which includes non-economic forms of capital, as opposed to the purely economic idea of 'human capital' (although Bourdieu does not use this term). To Bourdieu, the various types of resources vested in individuals, include cultural capital, which encompasses educational qualifications, along with social networks and kin groups (social capital) and prestige, status and authority (symbolic capital) (Bourdieu, 1983; Harker et al, 1990). McLennan (2012, p. 32) identifies additional types of symbolic and cultural capital such as experience, talents and imagination. Education often aims to invest students with these last two elements, and prestige, status and authority can arise from educational qualifications and achievement. In short, education both rests upon the natural world, and contributes to social and cultural wealth.

\section{AMARTYA SEN: EDUCATION AS A PATH TO FREEDOM}

'Education makes human beings more articulate. It transforms people. You can think differently about the world. It makes it possible for you to get jobs. It makes a dramatic difference. It generates a social equity that we need.'

$$
\text { -Amartya Sen }{ }^{2}
$$

\footnotetext{
${ }^{2}$ PBS, 2003.
} 
Amartya Sen is a leading theorist within welfare economics, social choice theory and development economics, and his work has a prominent place within education and development discourse. For Sen, education is one of the social goods which can expand a person's freedom and raise their quality of life.

In his 'capabilities approach' to development, Sen argues that education, as well as being a basic human right, is important for at least three reasons: (1) basic education, such as being able to read and write, has intrinsic value and contributes to development; (2) education can help displace exploitation, such as child labour; and (3) it can empower people who live with multiple disadvantages, such as gender-based inequality, remoteness, and physical disability (Sen, 1999, p. 4; Hill, 2017, p. 2). These freedoms are both the basic ends of development, and also some of the best ways to achieve it.

Basic education can also facilitate social change and even reduce fertility and mortality, and thus also has shared public benefits. In tandem with good health facilities and social security, education can promote high quality of life, even in low-income countries, and literacy and numeracy include the whole of a population in economic development, as workers who are not literate or numerate struggle to take advantage of global trade opportunities (Sen, 1999).

Sen emphasises the particular importance of education for girls and women. Education tends to reduce fertility rates, giving women the skills and time to undertake paid work and have greater influence over family decisions (Sen, 1999). Other research has also shown the intrinsic and instrumental value of education for women and girls (Gibson, 1999, Chant and Sweetman, 2012, Masuda and Yamauchi, 2018).

\section{PAULO FREIRE: EDUCATION AS OPPRESSION; EDUCATION AS LIBERATION}

Paulo Freire was a Brazilian educator and theorist best-known for his ideas of 'critical consciousness' and the 'banking model' of education. His work has had substantial academic impact, and informed more radical approaches to thinking on both education and development. He was born in Brazil in the 1920s, where slavery had only been abolished forty years previously and most of the population was deemed illiterate. Paulo Freire lived 
the disadvantage he later sought to rectify. He was born into extreme poverty, and hunger affected his ability to learn. He was forced to steal food for his family and dropped out of primary school. He later returned to school and, with the help of a partial tuition waiver, graduated from high school, and later went on to university. He worked as a teacher, researcher and social services government clerk and consultant (Collins, 1977; Kirylo, 2011). Whilst helping to develop literacy programmes in the 1960s he formulated 'cultural circles'. These were based on a participatory pedagogical model where teachers acted as coordinators and students as participants, and encouraged open dialogue rather than traditional lecture-style teaching (Collins, 1977). Freire's work as an educator epitomised the practice of a critical, transformative pedagogy for emancipation which he wrote about. He believed that education could enable students to recognise their own humanity and agency and realise their power to address poverty, hunger, oppression and injustice (Freire, 1996).

Like Sen, Freire views education as a way to achieve positive social outcomes. However, Freire does not view education as intrinsically good, and emphasizes its capacity to oppress as well as to liberate. To Freire, education can simply be an extension of a colonising culture, and it is necessary to decolonise education in order for it to be a liberating force (Freire, 1972; Freire, 1996).

Freire's concept of concientizição roughly translates to 'critical consciousness', or 'consciousness raising'. Freire defines it as the process of 'learning to perceive social, political, and economic contradictions, and to take action against the oppressive elements of reality' (Freire, 1972, p. 15). In order to start seeking liberation from systems of oppression, the oppressed must see the reality of their oppression, see its limiting influence on their lives, and confront it critically. This liberation can only be achieved through 'praxis', a reflection and action upon one's environment in order to transform it (Freire, 1972, pp. 25-28).

By contrast, in a 'banking' model of education, teachers present a narrative of reality that is detached from the existential experience of students, and where students are 'filled' with knowledge through mechanical memorisation. This teaching method positions the teacher as the 'subject' and reduces students to listening 'objects'. This type of learning, 'rote 
learning', is detached from students' lived experience, and it can act as a tool of manipulation and oppression (Freire, 1972).

Freire advocated a different method of teaching, a 'humanizing pedagogy' in which students and teachers have a more equal, creative relationship and construct reality together (Freire, 1972, p. 44-45). This participatory mode of learning encourages students to draw on their own experiences to contribute to the co-construction of knowledge in the classroom, building students' confidence in their own abilities and ensuring that what they are learning remains connected to their experience of reality.

\section{A RADICAL APPROACH TO EDUCATION}

Overton et. al. (2020) have identified a radical model of education for development, which has drawn from the work of Paulo Freire and others (Schor, 1992; bell hooks 1994, Mezirow 2000). This approach views education as a fundamentally political tool for radical transformative social change and encourages learners and teachers to work together to question and confront their own circumstances and the 'institutions, relationships, power dynamics and peoples that structure their lives' (Overton et. al, 2020, p. 16). Radical education projects are typically based within local contexts and centre on dialogue to encourage awareness-raising, which is then expected to converge with radical social change. These education practices generally remain outside the state due to their radical intentions, and instead are often conducted by non-governmental organisations (NGOs) in non-formal educational settings. An example of radical education is the nation-wide literacy campaign in Nicaragua, which was supported by Paulo Freire and carried out over five months in 1980. The campaign aimed to lift literacy rates and increase national integration. Urban middle and upper classes were sent out to villages as literacy facilitators (or brigadistas) in order to quickly lift literacy rates, especially among the rural poor. The program also promoted national integration, as by doing so these facilitators learnt about rural poverty and other key challenges facing the country. Radical education has a strong association with social justice activism by the Catholic Church, and seeks to address social marginalisation along the lines of class, race and gender. In post-colonial contexts, radical education has also focused on achieving a 'critical multiculturalism' to celebrate diversity and challenge the colonial idea of fixed culture and cultural identity. However, in the Pacific region, radical education 
has sometimes been seen as the continuation of Western influence in the sector rather than as a space to critique colonial legacies. Its nature also makes it challenging to implement, as those in power are unlikely to support challenges to existing hierarchies. However, the idea that 'education should support radical social change for equality' has informed global debates on education and development strategies (Overton et. al., 2020).

\section{DEBATE REGARDING THE ULTIMATE PURPOSE OF EDUCATION}

The differing views of Amartya Sen and Paulo Freire stem from disagreement over what should be the fundamental purpose of education. Sen sees education as a means of increasing a person's capabilities and freedoms in order for them to access more opportunities, be able to obtain stable, gainful work and achieve a good quality of life. He believes that an aim of education should be to increase social equality. His view implies the belief that education should be expanded and improved in order to be accessible for everyone regardless of class or gender. Freire, on the other hand, believes that education should be shaped to be a liberating force that enables its participants to be aware of the oppressive structures that they live within and are disadvantaged by. Oppressive types of education can serve to trap the working class in insecure, tenuous work.

\section{REIMER, ILLICH AND THE HIDDEN CURRICULUM}

Everett Reimer and Ivan Illich follow a Freirean line of thought. The two theorists studied the effects of schooling in poor communities of Latin America in the 1960s. Illich concluded from his research that institutions in Latin America in charge of education claimed to promote access and equity, but in fact did the very opposite, further entrenching elitism and inequality (Illich, 1973).

Across all countries and education levels, according to Illich and Reimer, education in schools serves four main functions. They have a 'babysitting', or custodial function; they sort children into a set of hierarchical roles within society; they contain a 'hidden curriculum' which encourages conformity; and only lastly do they teach skills and knowledge (Reimer 1971, pp. 23-27, in Hill, 2007, 3; Hill, n. d., p. 6). Reimer believes that the low priority given to students' acquisition of skills and knowledge accounted for low achievement and high 
costs of schooling, and both theorists argue that the hidden curriculum of formal schooling is the foremost threat to the declared aims of a given education system. (Reimer, 1971, p. 86). Hill describes the effects of a hidden curriculum that was present in the Timorese education system both under both Portugal and Indonesia. This will be explored in further detail in the next chapter.

Reimer (1971) argues that educational institutions socialize people into viewing learning as a commodity. By attaching learning to grades and certificates schools create the illusion of scarcity in learning and knowledge, as not everybody can be educated up to the level deemed adequate by powerful educational and other institutions. As that level is approached, competition increases the minimum level schooling regarded as necessary. Wealthy people typically attain this minimum, but the poorest generally cannot. As a result, school perpetuates social hierarchies despite claiming to promote equality.

\section{ALTERNATIVE IDEAS ABOUT DEVELOPMENT}

Alternative models of development generally have a greater focus on participation in development projects; on the environment; and on gender. Theories of alternative development originated in dependency theory, which in turn is part of the structuralist school of development. Alternative development draws on feminism, environmental sustainability, and participatory approaches.

Originating in the 1970s, this alternative, people-centred approach to development work emphasizes agency; in other words, people's capacity to create social change themselves (McLennan, 2012). Alternative approaches to development include Robert Chambers' arguments for the importance of making development projects participatory. Likewise, it includes J. K. Gibson-Graham's call for development practice to use an assets-based approach where there is a focus on the assets, capabilities and strengths of communities who are the focus of development projects (2005). Other alternative approaches include centralising gender equality and focusing on women's participation in development projects. 
McLennan emphasizes that alternative development is not a homogenous, unified approach (2012). Since the 1970s, alternative development has encompassed practically any kind of criticism of mainstream developmentalism, such as 'anti-capitalism, green thinking, feminism, eco-feminism, democratization, new social movements, Buddhist economics, cultural critiques, and even the post-structuralist analysis of development discourse' (Pieterse, 2010, p. 85). To reconcile this diversity Bebbington, Hickey and Mitlin (2008, p. 5) suggest thinking of alternative development in relation to little ' $d$ ' and big ' $D$ ' development (following Hart, 2001): in this conceptualisation little 'a' alternative represents alternatives to the underlying processes of capitalist development, and emphases alternative ways of organising the economy, politics and social relationships of society, while big ' $A$ ' alternative development focuses on alternative ways of intervening and actively managing development processes (McLennan, 2012).

There is general agreement on who should be responsible for development: grassroots popular associations, their associated NGOs, and local people (Sylvester, 1999; Wilson, 1996). An alternative development approach focuses on people and NGOs and favours grassroots-led development and de-centralization (McLennan, 2012). NGOs are esteemed due to their insight into the needs and desires of people themselves (Drabek, 1987; Porter \& Craig, 1997). McLennan's contention that NGOs 'help the poor achieve a voice of their own' (2012, p. 20) presents a rather idealised view of these organisations, but the message is nonetheless clear: 'small' organisations are better situated to undertake effective development work. Ultimately, alternative approaches to development focus less on increasing human capital in order to achieve material prosperity, and more on what constitutes a good life for a given individual or community (with reference to gender equality and the health of the environment), and how this might be realised.

Alternative ways of doing development broaden our store of knowledge and enrich our perspective. We have more conceptual frameworks which we can use. And they give us more tools to work with. If we have a wider perspective, and respect a broad range of ways of knowing, particularly those which have been undervalued, denigrated and ignored, then the development work we undertake may have a greater likelihood of being effective and successful (for example Gegeo, 1998). Education and employment can be viewed from 
frameworks which emphasize human well-being within community and within the environment as an objective of development work, and not just from the perspective of dominant development discourse.

\section{THE POST-DEVELOPMENT SHIFT: A QUESTIONING OF DEVELOPMENT}

Post-development theory sits within a wider postmodern 'turn' in the later stages of the twentieth century. It is characterised by a scepticism toward grand narratives of progress and objective truths within ideologies (Cahoone, 2003). Michel Foucault is the most prominent theorist of this time, and his interrogation of the historical processes behind power structures has influenced the field of development studies (Escobar, 1995).

Post-development discourse gained momentum through the observations of development practitioners, anthropologists, geographers and others of the evident failures of a one-sizefits-all approach to development in 'on the ground' projects (Rahnema with Bawtree, 1997). Theorists began to interrogate the origins and meaning of 'development'. There was a 'realisation that much of the underlying assumptions of development practice has been built on the belief that developing countries ought to be fundamentally reshaped in the image of the West' (Bulloch, 2014, p. 178). Escobar argues that the idea of the 'Third World' was essentially constructed in the post-war period to justify the need for development intervention in 'underdeveloped' regions of South America, Asia and Africa (Escobar, 1995). This construction and justification for intervention is exemplified in President Harry S. Truman's 1949 inaugural address, and has served to both legitimise and facilitate the expansion of global governance by emerging Western powers. Escobar views development as a means of control comparable to colonialism, which poor countries are virtually unable to decline politely. Dominant Western discourses reinforce a version of reality based on the 'political economy of the capitalist world economy' leading to a 'colonisation of mind' (Escobar, 1995, p. 18). Ultimately the problem with mainstream development that it is external and based upon the model of the industralised world and what is needed are more 'endogenous discourses' (Escobar, 1995; Pieterse, 2010). 
Escobar draws the work of Edward Saïd, who has highlighted the damaging practice of the West viewing the East as possessing a set of characteristics in opposition to itself, and 'othering' those which it views as fundamentally deficient through this binary comparison. Cowan and Shenton (1996) view the concept of development as profoundly influenced by Enlightenment ideas of linear progress and upward social trajectories, which rests on a belief in higher and lower stages of social improvement and there being superior and inferior forms of knowledge. Santos identifies five ways in which modern science, which rests upon the ideas of rationality and efficiency, devalues and delegitimises all which lies outside the 'scientific, advanced, superior, global or productive realities' (2004, pp. 238239). This serves to present peoples and areas which fall outside this ideal as 'ignorant, residual, inferior, local and non-productive' and in need of development. Thus, the term 'development' itself contains the imperative to intervene in the 'Third World' in order to improve it (Cowen \& Shenton, 1996).

Post-development theorists have highlighted the emphasis of mainstream development on the capitalist economy at the exclusion of all else. Healy (2009) contends that when the capitalist economy is seen as the most real, dominant and powerful economic set-up, its alternatives are typically considered inferior, idealistic and powerless in comparison. Santos describes this as the 'monoculture of capitalist productivity and efficiency', which seeks 'growth through market forces' and discredits non-capitalist activity as non-productive (2004, p. 239). Fleming (2015) contends that the view of education as an essential means of achieving social and economic goals and the global education agenda has led to a Western model of development being implemented hegemonically in developing countries, which overlooks the purpose and relevance of education for local contexts.

Bulloch (2014) deliberately turns away from mainstream development theory and practice, which originates from Western worldviews, and towards local notions of development in the Philippines. She finds that such notions are complex, and differing visions of, and attitudes toward, development not only vary between individuals in a society, but may be held simultaneously by an individual themselves. She concludes that a 'single coherent version of an ideal life' would be difficult to find within any society, and suggests viewing development as a myriad of possibilities rather than as one unified path. 


\section{SEEKING A WAY TO LIVE WELL}

Buen vivir (also known as vivir bien, 'living well') is a complex set of ideas, worldviews and knowledge from indigenous movements, scholarship and activist groups which has emerged from Andean countries of Latin America (Ranta, 2016; Gudynas, 2011). In the twenty-first century some popularly elected governments in Ecuador and Bolivia have reversed their neoliberal policies in favour of these indigenous conceptions of human wellbeing (Radcliffe, 2012).

As a social philosophy, buen vivir means 'good living', or 'well living', and offers an alternative to the Western conception of development, as it 'focuses on the good life in a broad sense' (Gudynas, 2011, p. 441), and not just on economic growth. Wellbeing centres on the individual within the social context of their community and their unique environment (Balch, 2013). Notably, buen vivir offers 'good living' goals as an alternative to the SDGS (Cuestas-Caza, 2018). It is an umbrella term encompassing Sumak Kawsay (in Kichwa, a major indigenous language spoken in Ecuador and the Andes) and Suma Qamaña (Aymara) (Gudynas, 2011).

Sumak Kawsay is part of the cosmovisión (worldview) of Quechua peoples of the Andes. It describes a way of doing things which is 'community-centric, ecologically-balanced and culturally sensitive' (Balch, 2013), and is opposed to social injustice and the exploitation of natural resources. Cuestas-Caza (2018) has stressed that buen vivir and sumak kawsay are not intechangeable, as they are contextually, epistemologically and ontologically distinct.

In 2008 the Ecuadorian government revised its constitution to read:

"We... Hereby decide to build a new form of public coexistence, in diversity and in harmony with nature, to achieve the good way of living, the sumak kawsay" (Preamble to 2008 Ecuador Constitution in Radcliffe, 2012, p. 241).

The similar Aymara concept of suma qamanā has emerged in Bolivia and similarly been incorporated into the Bolivian Constitution in 2009 (Gudynas, 2011). 
Radcliffe (2012) explains that this constitutional commitment and adoption of sumak kawsay is part of Ecuador's 'postneoliberal development agenda' which aims to address material and social equalities associated with neoliberal and capitalist development. However, while the adoption of sumak kawsay aims to address social and material inequalities in the country, in practice the state is unwilling to give up territorial rights and autonomy to its citizens. Its selective use and interpretation of certain constitutional principles has merely served to reproduce 'postcolonial hierarchies' of race and poverty, and 'the language of sumak kawsay has been used to cloak postcolonial development as usual' (Radcliffe, 2012, p. 248).

Ranta (2016) reaches parallel conclusions in her study of the incorporation of vivir bien into state policy-making in Bolivia. There is an inherent contradiction between the egalitarian, utopian ideal embodied in Vivir Bien (a.k.a buen vivir), and its application in state formation. Governing using the principle of Vivir Bien means governing through 'plural political formations' which results in a paradox: the state becomes both an object and an instrument of change. In practice, however, instead of decolonising the state by blurring state-society boundaries, the transformation of the state according to principles of Vivir Bien has led to the Bolivian government co-opting social movements into its institutional structures, thereby exerting greater discipline over them.

While the conclusions of Radcliffe and Ranta are rather discouraging, the alternative notions of well-being within the buen vivir umbrella of indigenous traditions remain valuable as critical reactions to classical Western development theory which explore possiblities beyond Eurocentric notions of development (Gudynas, 2013).

\section{THE DIVERSE ECONOMIES FRAMEWORK}

Partner theorists J. K. Gibson-Graham have recognised that there are different ways of living and different types of economy which are overlooked by Western capitalist conceptions of development. Gibson-Graham (2005) have challenged the idea that development can only be achieved through a 'capitalocentric' economic model by examining a range of diverse economic activities that have been found to support livelihoods in reality. The theorists consciously distance themselves from the binary view of the economy described by Healy 
(2009) and move towards a view of 'radical difference; of diverse capitalist and noncapitalist forms', seeking to show that another world outside the capitalist economic paradigm is possible (Gibson-Graham and Roelvink, 2011, p. 29).

Their alternative framing of economy includes the multiple forms of economic activity which already exist. Gibson-Graham and Roevink (2011) use a simple template to illustrate diverse economies:

Table 1: A Diverse Economy Framing

\begin{tabular}{|l|l|l|}
\hline Transactions & Labour & enterprise \\
\hline Market & Paid & Capitalist \\
\hline Alternative Market & Alternative Paid & $\begin{array}{l}\text { Alternative } \\
\text { Capitalist }\end{array}$ \\
\hline Non-Market & Unpaid & Non-Capitalist \\
\hline
\end{tabular}

Source: Gibson-Graham and Roevink, 2011, p. 30.

In 2005, Gibson-Graham studied a move by the local government of Jagna, a town port in the Philippines, to explore alternative development pathways using participatory rural appraisal methods.

The authors propose a diverse economy framework to challenge the hegemonic view of mainstream development that capitalist economy is the only viable type of economy, and that capitalist productivity is the only means of creating economic development (in other words, production of commodities for the global market, capital accumulation and export led growth). Gibson-Graham use three sets of economic relations to structure their idea of the diverse economy:

(1) Transactions of goods, services and finances;

(2) Labour, encompassing the performance and ways of remunerating it; and

(3) Kinds of enterprise which produce, appropriate and distribute surplus. (2005, p. 12). 
Their research team worked to identify the assets and strengths of the Municipality through an 'assets' map (including physical business and infrastructure, social strengths and natural environment). They then used a Diverse Economies Framework (DEF) to table the multiple economic activities which sustained these assets and strengths:

Table 2: A Diverse Economy

\begin{tabular}{|c|c|c|}
\hline TRANSACTIONS & LABOUR & ENTERPRISE \\
\hline MARKET & WAGE & CAPITALIST \\
\hline Alternative Market & Alternative Paid & Alternative Capitalist \\
\hline $\begin{array}{l}\text { Sale of public goods } \\
\text { Ethical "fair-trade" markets } \\
\text { Local trading systems } \\
\text { Alternative currencies } \\
\text { Underground market } \\
\text { Co-op exchange } \\
\text { Barter } \\
\text { Informal market } \\
\text { Alternative credit }\end{array}$ & $\begin{array}{l}\text { Self-employed } \\
\text { Cooperative } \\
\text { Indentured } \\
\text { Reciprocal labour } \\
\text { In kind } \\
\text { Work for welfare }\end{array}$ & $\begin{array}{l}\text { State enterprise } \\
\text { Green capitalist } \\
\text { Socially responsible firm } \\
\text { Non-profit }\end{array}$ \\
\hline Non-market & Unpaid & Non-capitalist \\
\hline $\begin{array}{l}\text { Household flows } \\
\text { Gift giving } \\
\text { Indigenous exchange } \\
\text { State allocations } \\
\text { Gleaning } \\
\text { Theft, poaching }\end{array}$ & $\begin{array}{l}\text { Housework } \\
\text { Family care } \\
\text { Neighbourhood work } \\
\text { Volunteer } \\
\text { Self-provisioning labour } \\
\text { Slave labour }\end{array}$ & $\begin{array}{l}\text { Communal } \\
\text { Independent } \\
\text { Feudal/Peasant } \\
\text { Slave }\end{array}$ \\
\hline
\end{tabular}

Source: Gibson-Graham, 2005, p. 12.

The authors identify a range of transactions, forms of labour and enterprises which fall outside the conventional capitalist economy. Their depiction of Jagna's diverse economy 'knocks capitalist activity off its perch', revealing a range of economic relationships and activities which do not follow its 'governing laws and logics' $(2005$, p. 13).

The approach reveals a culture of sharing and cooperation attached to a range of economic activities including barter, reciprocal labour, flows of money and goods in ceremonies and rituals such as weddings and funerals, trade in second-hand clothes, and various ways of obtaining money other than by formal bank loans. 


\section{PLACE-BASED EDUCATION}

Gibson-Graham and other post-development theorists (including Fleming and PalominoSchalscha, 2016) have championed place-based education initiatives, due to the recognition of these authors of the negative effects that the imposition of development can have on established societies and cultures. Place-based approaches to education are based on local epistemologies and types of knowledge (Overton et. al., 2020). Teachers aim to address the needs formulated by communities themselves, and deliver education based on the communities' values, aspirations and resources. These forms of education can be quite diverse and involve learning across a wide range of worldviews, knowledge systems, languages, traditional skills and customs. They focus on contextualising education and prioritise primary education. These approaches can constitute a kind of resistance to the modern Western-centric world and the foreign values and forms of knowledge introduced by outside actors such as NGOs, and may help students to understand the tensions between local and foreign elements. Local forms of education may include stories, music, histories, ecological knowledge, spirituality and religious science, including agricultural and fishing techniques as part of connecting students to the ontologies and epistemologies of their cultural heritage. These approaches may incorporate new skills, techniques and ways of thinking (such as new technical skills or financial management), and these more hybrid forms of knowledge may challenge existing social norms and power relationships. These strategies may have difficulty attracting funding from governments and overseas donors, and the need for resources often leads to connections with NGOs, religious institutions such as churches, and governments, whose support often complicates the formulation and delivery of place-based education (Overton et. al., 2020, pp. 12-16).

\section{USING A DIVERSE ECONOMIES FRAMEWORK TO EXPLORE EDUCATION}

So far there are few examples of Gibson-Graham's DEF being applied to education. Fleming (2015) has used the approach to analyse rural training centres in the Solomon Islands, but so far it has not been used to examine education in Timor-Leste. 
I draw on Gibson-Graham's conception of diverse economies to the education system in semi-rural Timor-Leste in order to better understand the context in which teenagers are thinking about their future plans for work and study. I observed and was told of many alternative and non-market activities similar to those described by Gibson-Graham during my fieldwork in Timor-Leste, and the DEF has allowed fuller, broader understanding of the various economic activities and relationships within Ermera subdistrict. The economy in which teenagers will soon seek work is by no means a solely capitalist economy, particularly in rural communities.

\section{DECOLONISING EDUCATION FOR DEVELOPMENT}

\section{DECOLONIAL THEORY}

In 1960 the United Nations General Assembly issued a Declaration on the Granting of Independence to Colonial Countries and Peoples, which is seen as a milestone in the history of decolonisation (Adebisi, 2016).

Decolonial theory emerged from post-colonial countries in South America, and includes Escobar's work. Linda Tuhiwai Smith describes decolonisation as a 'long-term process involving the bureaucratic, cultural, linguistic and psychological divesting of colonial power' (2012, p. 101). Decolonisation is an epistemic project which tackles the ongoing oppression and domination of Western privilege that silences non-Western voices and the effects of people and regions being represented as economically and mentally underdeveloped (Harvey and Russell-Mundine, 2018). It seeks to undo the 'epistemic injustices' caused by the preeminence of Western culture and thought within institutions such as universities.

Development theorists such as David Gegeo have called for a greater attention and valuation of indigenous knowledge, and development to be based on the knowledge and needs of communities rather than models of development imposed from outside. Gegeo (2008) argues that development dictated from the outside will not match with local needs, and rather, should come from within communities. Attempts to understand local knowledge systems can increase the success of development projects and help to ‘dehegemonize' globalizing Western knowledge structures (Gegeo, 1998, p. 308). 


\section{DECOLONISING EDUCATION}

Decolonising knowledge has been identified as a means of improving education and engaging everybody in education systems, particularly in post-colonial countries, and striving for equality between different epistemologies and knowledges.

According to Estrada (2012), a Guatemalan indigenous academic, efforts to decolonise academia are increasing, particularly in Africa, Australia, Canada, New Zealand, and the United States, all of which are countries that have been colonised. Theorists who write about decolonisation in education generally agree on two main points:

First, educational systems of postcolonial states are generally characterised by a kind of poverty that has arisen from indigenous systems of knowledge being devalued, ignored and erased. Western epistemology is valued higher than indigenous knowledge and culture, which leads to the erosion of these non-Western epistemologies. Spivak (1988) refers to this as 'epistemological silencing', and similarly, Harvey and Russell-Mundine see this as a kind of epistemic injustice caused by a 'system dominated by Western thought' $(2018$, p. 3). In her work on Guatemala, Estrada argues that the Western philosophical foundations of the country's education system have variously stereotyped or erased the knowledge of the country's indigenous population.

Second, including indigenous knowledge in Western-dominated, post-colonial education systems is an important part of decolonisation, and may enrich them. For instance, Estrada argues that, in Guatemala, Maya indigenous knowledge helps to achieve social change both inside and outside educational institutions. Indigenous knowledge and indigenous voices form a political vehicle that has the potential to decolonise the mainstream education system to better meet the needs of indigenous groups (2012). Some decolonisation scholars draw on Freirean theory. Drinkwater (2014) argues for the importance of 'transformative education', which is a prominent feature of Freire's theory on critical consciousness in education, and Adebisi (2016) recommends a critical Freirean approach for decolonising education in African states. 
Including indigenous knowledge in curricula may even lead to economic growth. According to Musitha and Mafukata (2018), decolonising the education system in South Africa is viewed as a means of creating human capital and promoting economic development, thereby reducing poverty. In the case of Timor-Leste, Hill argues that 'overcoming the low status of indigenous knowledge in education systems is particularly crucial for development and needs to be addressed ... if agricultural productivity is to increase' (Hill, 2005, p. 106).

\section{DECOLONISING EDUCATION IN OCEANIA}

Discussion on decolonising education in the Pacific dates back to the 1970s. Vulliamy (1981, p. 4) cites a growing awareness of the irrelevance of western scientific education for many developing countries, including arguments that it inhibits these countries achieving their economic and political goals (following Carnoy, 1974). Vulliamy studied the move to tie student learning more strongly to community development in high schools in Papua New Guinea. This large Pacific nation has inherited a Western colonial model of schooling from Australia. Upon gaining independence in 1975, the Ministry of Education rewrote the primary and secondary curriculum to include Papua New Guinea materials and culture, and most high schools developed activities based on typical rural occupations such as subsistence farming, fishing and animal husbandry. However, assessment was entirely based on exams in Mathematics, Science, English and Social Science. The Secondary Schools Community Extension Project (SSCEP) aimed to integrate practical and intellectual skills by developing community-oriented learning programmes on rural outstations, enabling students to contribute to rural development through self-employment, and reducing urban drift. The SSCEP is notable because it is an example of a Ministry of Education in a neighbouring developing country to Timor-Leste not only including practical and traditional skills in schooling, but making a move to re-orient high school learning toward community development rather than to formal professional work through a focus on Western scientific knowledge in order to achieve national development goals. Part of the SSCEP project involved changing the examination style to be skill- rather than content-based. 
Forty years later, Eve Coxon (2020) has argued for the decolonisation of 'education for development' discourses which permeate aid projects in Oceania, and the role that indigenous research methodologies should play in monitoring and evaluation of aid-funded school improvement interventions. Coxon also argues that it is important to value indigenous knowledges and recognise their presence within language itself. In bilingual and multilingual contexts, literacy in local languages enables students to connect themselves with this knowledge and use aspects of it to expand their understanding of the world, meaning that literacy should be viewed as more than the imparting of basic knowledge (Coxon, 2020).

According to Johansson-Fua (2016), the epistemologies and ontologies indigenous to the Pacific Islands must be made essential within education in order to achieve sustainable and transformational development. For Coxon, this inclusion must address the 'north/south relationship' which defines education across the Pacific region.

It is important to recognise that Western knowledge as reproduced through education is not necessarily inappropriate or harmful to indigenous ways of life in a given locality. While discussing the education curriculum in the 1980s, Yolnu elders in north-east Arnhem land of Northern Australia reassured white Australian school teachers that 'Western knowledge practices are useful for Aboriginal people too, in appropriate framing' (Christie, 2015, p. 98).

\section{DECOLONISING THE CURRICULUM: CASE STUDIES}

One way to decolonise schooling in a given place is to implement a local curriculum which teaches students in their first language and which bases itself within their culture, allowing them to learn more about their heritage. There some are recent examples of this effort to decolonise what is taught in schools in order to engage students with the indigenous knowledge that is part of their heritage as part of their learning. 
At Yuendumu School in central Australia, a community-funded local curriculum has been implemented at the community school. The remote school has a bilingual approach to teaching based on a 'staircase model', where younger kids are taught in Walpiri and then eased into English at higher year levels. Students are also taught about Walpiri culture. The programme was developed by community elders (Lee, 2008; ABC, 2018).

The Cook Islands has also developed and implemented its own curriculum up to Year 10. Prior to this, the Cook Islands used the New Zealand school curriculum, with a strong migration flow between the two countries pulling students away to New Zealand to study at primary and particularly secondary level (Bertram, 2018). The curriculum both includes the cultural and spiritual beliefs and values of the Islands and aims to equip students with skills geared toward finding work either on the Islands, where tourism is the main economic sector, or outside them. It includes marine studies, bilingualism and bilingual education, and frames health and physical education within wellbeing (Cook Islands Ministry of Education, 2014).

The central aim of the curriculum is to:

'Give students the opportunity to learn about Cook Islands Culture and Language ... and ensure that Cook Islands cultural traditions, spiritual beliefs, histories and events are recognised and respected' (Cook Islands Ministry of Education, 2011, p. 5).

The Primary Enterprise Programme taught at primary level includes units on Identity, Culture and Organisation and the Economic World. The latter allows students to practice investing in their business, buying one another's products and services and paying taxes, which aims to equip students with the kind of business and entrepreneurial skills and competencies which will best enable them to find work, either within the tourism-oriented economy of the Islands or in large neighbouring countries such as New Zealand and Australia (Cook Islands Ministry of Education, 2011). 
Another example of a place-based curriculum, also geared toward local livelihood objectives, is a set of grounds-up curriculum resources formulated in East New Britain of Papua New Guinea. Between 2015 and 2017 a team of local educators designed, developed and implemented a Tourism and Hospitality Curriculum to provide culturally relevant and industry-responsive vocational education and training. The Curriculum Development Project (CDP) is both locally-made and locally-oriented, intended to support local ownership of moves toward sustainable development of the tourism sector and strengthen local economic governance in East New Britain Province. The implementation model of the project emphasized participation of all teachers, stakeholders and beneficiaries, and was launched in 2017 under the guidance of local educators for implementation across urban and rural areas (Dela Torre Para, 2020).

\section{DEBATE WITHIN DECOLONISING EDUCATION: ESCOBAR AND FREIRE}

The work of Paulo Freire and Arturo Escobar have given rise to debate on the nature of education which might facilitate a 'decolonisation of the mind' for previously colonised peoples. While both theorists were born in South American countries, they were born at different times and in very different circumstances. Paulo Freire wrote from an educational perspective, while Arturo Escobar is an anthropologist and development philosopher who was born thirty years after Freire, and came of age as poststructural, postcolonial and postdevelopment theory was really getting started. In this light, it is little wonder that they have divergent perspectives on what kind of education might best enable people to challenge oppressive structures created by colonial administrations.

Paulo Freire, a pioneering educator, believes that education can be transformative if it is imparted in the right way and is connected to participants' own daily reality. Once participants - specifically poor, illiterate workers - learn to read, write and gain confidence in their own knowledge they can start to recognise and tackle the structures which oppress them.

On the other hand, Escobar would argue that, given the increasing influence of the hegemonic worldview created by advanced capitalist countries, it is not enough to change the delivery and ensure the relevance of education to students' lives, as education itself may 
reinforce oppressive structures and systems of thought, leading to a colonisation of reality (1995). Education must be reoriented to ensure that it is both based on students' context and presents alternatives - 'new ways of thinking and doing' - to dominant global discourses (1995, p. 20).

The perspectives of the two theorists are not necessarily incompatible. Ideally education can be delivered in a participatory, generative way which encourages self-confidence and critical thinking, and which both challenges and presents alternatives to dominant epistemologies and paradigms.

\section{WHAT TYPE OF EDUCATION, AND WHAT TYPE OF DEVELOPMENT?}

While there is general consensus that education is good for development, there is less agreement on which particular type of education might achieve particular development outcomes.

Several theorists agree that different types of education may be used in different ways to alleviate poverty, promote economic growth, or overcome inequality and oppression (Knuttson and Lindberg, 2012; Gruber and Kosack, 2014; Gamlen et. al., 2017; Datzberger, 2018). As outlined already, various studies have focused on the need to decolonise education and explored ways to do it. However, this literature generally comes from an educationalist perspective, asking how and what knowledge should be taught, rather than engaging with debates within development. For instance, what kind of education should be delivered, and what should be taught, in order to achieve a desired type of development?

\section{CONCLUSION}

Literature on education and development generally holds that education is important for development. However, barely any research explores what type of education can lead to what kind of development, or what the purpose of education should be, or how a given type of education should be delivered in order to achieve a particular development strategy. 
Three bodies of knowledge contribute to a better understanding of the connection between education and development: education theory; post-development and decolonial theory; and alternative development and conceptions of well-being. These bodies surround the question of how education might be used to achieve the desired outcomes of different development models. So far, perhaps the only studies which link these bodies up have been by Overton et. al. (2020) and Fleming (2015), focusing on Oceania and the Solomon Islands respectively. I aim to follow their example and use these three disciplinary perspectives to examine views of education and aspirations for the future in semi-rural Timor-Leste. 


\section{Chapter 3: Methodology and Methods}

The goal of this research is to explore teenagers' aspirations for the future in order to determine the appropriateness of education for local livelihoods in Ermera subdistrict of Timor-Leste. The chapter begins by describing the philosophical foundations of the research and the position from which I write. I will then explain my choice of site and my research method. The chapter will conclude with a list of ethical considerations and reflect on how the data collection process went in practice.

\section{PHILOSOPHICAL FOUNDATIONS AND POSITIONALITY}

This research takes a post structural approach. This is in order to explore divergent and convergent views on education and social issues, as well as to uncover covert power structures that exist within the education system in Timor-Leste and highlight social and global inequalities made apparent by the relationship between education and livelihoods.

Following Michel Foucault (1975), knowledge is shaped by political, social and spatial processes through time. Post-structuralism emphasizes that knowledge is socially constructed rather than being objective, particularly through language, and that all language is mediated in some way (Woodward et. al., 2009). Language often creates and perpetuates binaries. Representing something as 'is', such as 'developed', creates an opposite where all that 'is not' is 'underdeveloped' (Hall, 2002). In development discourse this 'defines and leads more than half of humanity to perceive themselves as underdeveloped' (Agostino, 2002, p. 228). Post-structuralist theorists challenge the 'claims of truth' by Western and capitalist economic thinking which have been embedded within the dominant discourses of development (Kitchin \& Tate, 2000). This research aims to acknowledge alternative meanings and discourses, diverse understandings and pathways to development. This is to centralise the 'other' that has been framed as inferior, omitted or excluded (Santos, 2004). 
The work of Edward Saïd also provides a useful framework for conducting research in a developing country in the Global South. Saïd draws attention to the act of 'otherising', of making binary distinctions and drawing generalisations (2003). I have adopted this lens in order to remain conscious of drawing comparisons between myself and participants in my research.

This philosophical stance leads to the adoption of a social constructivist epistemology, which views knowledge as diverse and 'created' in different social and cultural contexts. Social constructivism views knowledge as socially constructed rather than being objective and neutral, as it is based upon a collection of ideas and concepts created by people. Knowledge is influenced by human interests, and all knowledge reflects power relationships and social dynamics within society (Scheyvens, 2003; Mertens, 2005).

\section{QUALITATIVE AND QUANTITATIVE APPROACH}

I took both a quantitative and qualitative methodological approach to research. I conducted surveys with senior secondary school students in their final year in order to gather a large amount of 'quick' information. The surveys also gave me a chance to engage directly with a large number of students and make my reason for being at their school explicit. The surveys gathered some basic quantitative data on students' age, gender, plans in the future, typical household chores and their parents' occupation.

I used the data from the surveys to verify and frame a number of more in-depth individual interviews with teenagers and parents. These interviews were an opportunity to ask participants for their views and opinions in order to gauge how they viewed education and work, and get a sense of key concerns and priorities among parents, teachers and school principals, as well as the views of professionals outside Ermera subdistrict. These interviewers were qualitative, providing data on aspirations, attitudes and perceptions on education and local livelihoods. 


\section{ETHNOGRAPHY AND PARTICIPATION}

I adopted an ethnographic and participatory methodology to pursue a broad and in-depth understanding of education and livelihoods in the communities in a respectful and inclusive way. My approach to fieldwork has been shaped by the advice of Siobhan McDonnell, a Legal Anthropologist at the Australian National University, who encouraged me spend at least a few months making myself useful in my chosen site in order to counterbalance the extractive nature of fieldwork, particularly given my position of relative power as a white researcher in an indigenous setting (Smith, 2012), as well as to seek ways to make my research more participatory. In taking a participatory research I sought to mitigate the power imbalance between researcher and researched, and empower participants to analyse and interpret their own context (Chambers, 2007). I have also endeavoured to prioritise the personal connections made with residents of Ermera subdistrict. ${ }^{3}$

Ethnographic research is characterised by a drive to understand the world views and ways of life of people in the context of their everyday lived experiences (Crang \& Cook, 2007). It is an engaged, first-hand look at culture and society (Davies, 2008; Murchison, 2010). According to Wolcott (2008), ethnography centres on a holistic approach, taking into account the whole social setting, relationships and the wider economic and political context.

A teacher who lived in Ponilala, a suku (village) in Ermera subdistrict, was enthusiastic about my idea of interviewing parents of teenage students, and voluntarily found a number of parents who were willing to talk to me. He accompanied me to visit these parents and helped to translate participants' responses while my Tetun was still limited.

\footnotetext{
${ }^{3}$ The relationships I have built with students and teachers include providing some financial support to some after I've left. In this way I have been able to support in turn those who helped and supported me both personally and research-wise. I provided support only after I'd finished all data collection.
} 
I asked two teenage students to act as research assistants when I conducted surveys with Grade 12 students at their schools. I also asked one of these students to act as a translator for some of the interviews with students in Ponilala. They were both students I had spent some time around in the two months prior to conducting surveys and interviews, one at a school and the other at an extracurricular course.

Part of my research approach is yet to be completed. After completing this thesis I intend to return to Ermera subdistrict and give copies of my thesis to the two school directors, who supported my research in their senior secondary schools, and also give copies to the three families who looked after me during my stay. Again, this is to 'give back', because this research is as much the participants' and the two schools' work as it is mine. I am looking forward to spending time with the students, teachers and families I met and doing another period of volunteering as an English teacher, and perhaps running an art class, without the time constraint and pressure of conducting research. I will also submit a copy of my thesis to the Ministry of Education (MoE), as a senior education official indicated that the Ministry would be interested in the results.

\section{POSITIONALITY: A MALAE VISITING THE FOHO}

I write from the position of a white research student conducting fieldwork in a small developing country. I enjoy a range of unearned privileges and advantages because I am Caucasian and I was born in a middle-class Australia family and grew up in the capital city, which has the highest per-capita income in the country. These factors shape my interpretation of my experiences, observations and findings. There is no 'view from nowhere': my worldview is shaped by my identity, rather than being neutral or objective. The results of my research should be read with a full recognition of the limitations of my understanding due to my identity.

My positionality is also formulated in relation to others. Following Charles Cooley's social constructivist view of the self, 'I am not who you think I am; I am not who I think I am; I am who I think you think I am': my identity was also shaped by the society I volunteered and conducted research in (Cooley, 1902, pp. 183-184). In Ermera subdistrict, I was malae, 
mana/biin, mesak, mestra, peskizadora: 'foreigner', 'young woman', 'alone', 'teacher', 'female researcher'. In essence, I was a malae feto (female foreigner) visiting the foho ('mountains', a colloquial name for the rural districts).

The position of power afforded me from being a malae made a strange contrast to being single, relatively young and female. Linda Tuhiwai Smith's work on decolonising methodologies encouraged me to be mindful of my relative position of power as a white researcher in an indigenous context. I enjoyed the privileges of being a malae and being able to afford a motor ${ }^{4}$, which gave me a greater ease of mobility, but I faced gender-based restrictions. I often felt vulnerable. I was repeatedly represented as mesak (single, or solitary), which I began to realise was not viewed positively: a malae operating alone was relatively acceptable, but as a woman it was not. I came to understand too late that operating as an individual was at odds with what was acceptable for women in a sociallyoriented, patriarchal society. As a foreigner I could talk to many residents; men and women, adults and children. However, spending time in Ermera as a young female foreigner was often challenging. It was difficult to build relationships, conduct my research and feel safe when I felt sexualised by many men and boys, not just by strangers on the street but by teachers and teenage male students, and groped by little boys less than half my height, even when I was in the company of other Ermera residents. I was an outsider and still learning Tetun, making me an easy target. This generally low-level yet constant sexual harrassment was at times profoundly isolating and distressing. I never felt entirely comfortable or safe, although I felt significantly more so in Ponilala, suggesting that sexual harrassment is more commonplace in larger district hubs than in smaller rural villages. ${ }^{5}$

\footnotetext{
${ }^{4}$ The general word for motorbike, which includes semi-automatic motorbikes and scooters.

${ }^{5}$ This view was shared by some US Peace Corps volunteers I talked to, who had lived in the country for a couple of years.
} 


\section{LOCATION RATIONALE}

\section{TIMOR-LESTE}

I had also previously volunteered for an NGO from my hometown (Canberra) which had just started a project in Dili, and this influenced my decision to conduct research in Timor-Leste. The in-country manager became a supportive contact over the total of twenty-two weeks I spent in Timor-Leste. Over December 2018 to February 2019 I volunteered for a local NGO in Dili as part of my effort to 'give back' during my research. This enabled me to establish personal connections and gain some familiarity with the context in which I was planning to conduct fieldwork.

\section{ERMERA SUBDISTRICT}

I chose to base my research in a major town of Ermera subdistrict because geographically it was a compromise between the urban capital of Dili and the rural setting of the rest of the country. Ermera vila has kiosks, markets, schools and it is a business hub. It is only three hours from the capital by public transport, or two hours by motorbike. It is a regional hub of commercial activity. The schools in Ermera vila included both a public and a private Catholic senior secondary school, which provided a useful comparison between private and public secondary education. The two school directors were also open to me volunteering as a teaching assistant in the June to September period.

I was initially invited to visit Ermera vila by a friend I met in Dili who had been volunteering for eighteen months in Mirtutu, a suku located a half-hour's walk from Ermera vila. This meant that during fieldwork I had a contact nearby who provided me with some security and support as I found my feet, introduced me to the directors of the two schools, and helped me find somewhere to stay.

\section{RESEARCH DESIGN}

This research employed both quantitative and qualitative methods to collect data in order to understand educational experiences and obtain an overview of local livelihoods in Ermera subdistrict. 


\section{TIMING}

I conducted fieldwork during the coffee-harvesting period, which runs from roughly May to August. This was a good time to stay in Ermera vila. I could observe first-hand how the majority of residents were engaged in coffee harvesting activities to some degree, and it was the dry season, which meant cool and sunny weather, and was the easiest and safest time to travel.

\section{OBSERVATION THROUGH IMMERSION}

On the advice of Siobhan McDonnell, I took a relatively long and 'slow' immersive approach to research, spending a total of twenty-two weeks in Timor-Leste including sixteen weeks of collecting data, and eleven weeks living in Ermera subdistrict. Employing the ethnographic method of immersion involved reflecting on conversations and observations that arose while living in Ermera subdistrict and participating in daily activities (O'Leary, 2010). Making myself useful and offering my services as an English teaching assistant at the two senior secondary schools more than a month prior to data collection allowed time to establish connections with students and other community members.

By focusing on the 'small', local experiences of students and their families, my approach turns away from the 'top down' nature of related studies, which tend to prioritise 'big' international and government viewpoints (Capelo \& Cabrita, 2015; Lucas et. al., 2015; World Bank, 2013). In partular Capelo and Cabrita (2015), in their research on the 2015 curriculum restructure in Timor-Leste, focus on the views of leaders, government leaders, then Portuguese trainers and Timorese teachers, only lastly exploring student experiences through focus groups. My approach is an attempt to invert this common hierarchy within research.

After being invited to visit a free English course run in Ponilala, I began volunteering as a teacher there, and came to spend a significant amount of time there and started to build friendships with students from the course. During the lessons I strove to have students construct the lesson content with me, inspired by reading Paulo Freire's participatory approach to teaching. I asked what they would like to learn about, encouraging dialogue during lessons (even if it was just to repeat words to work on their pronunciation). As well as 
working on pronunciation I asked them questions which they could answer verbally or write on the blackboard. For instance, I would introduce a topic such as 'animals', 'cooking', 'jobs', 'professions', or 'colours', and encourage them to build a collection of associated vocabulary with me. I taught them Australian folk stories, and asked them about their own. I taught some Australian slang words, which were welcomed enthusiastically, and introduced some English songs such as 'Feeling Good' by Nina Simone and 'Three Little Birds' by Bob Marley, playing them on my phone for the students to sing along to. These lessons afforded me some insight into what teenagers viewed as a good life (See Appendix 6).

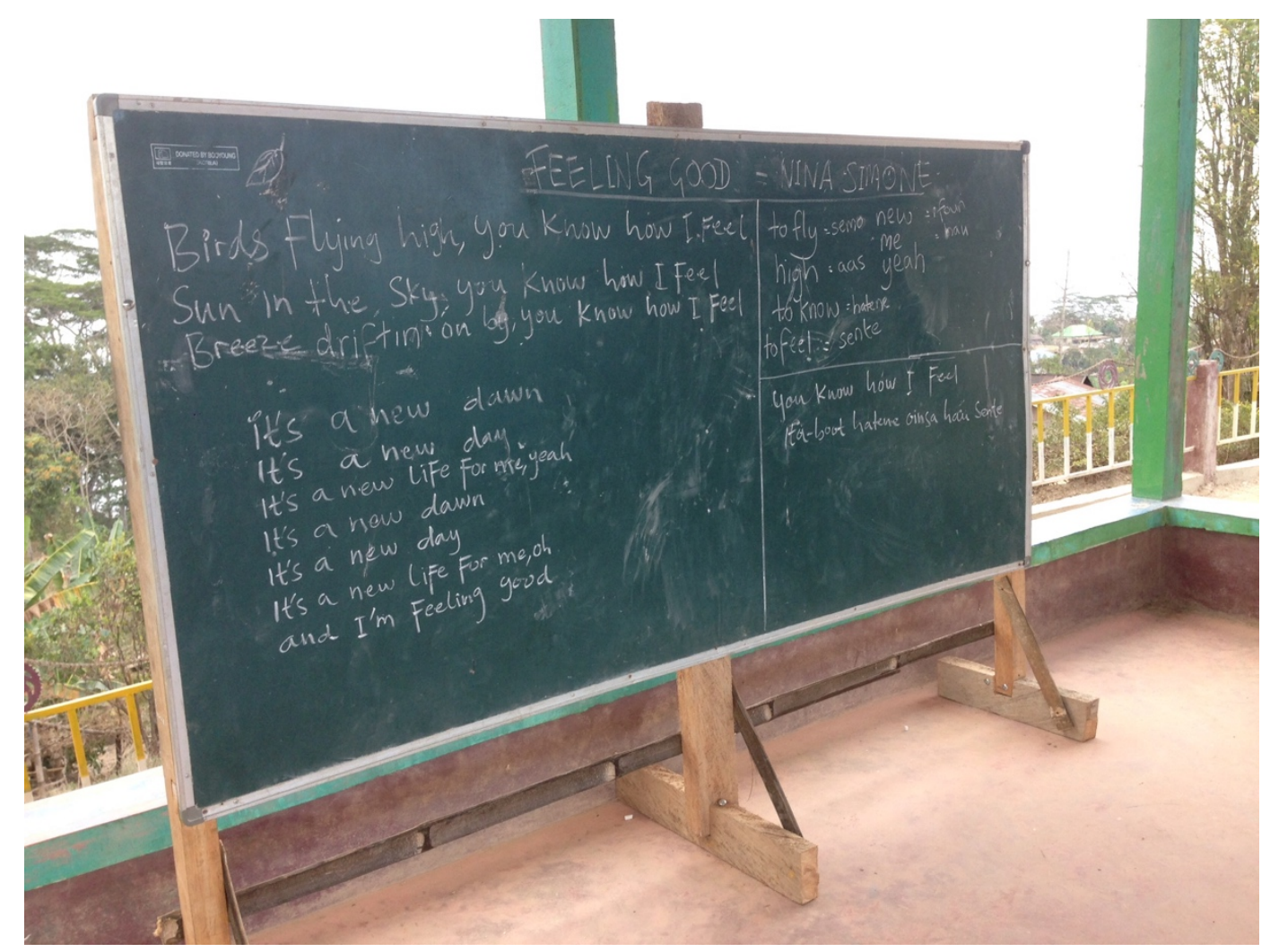

Photo taken during class on 'Feeling Good' by Nina Simone. Source: own image.

During this period of 'giving back' I endeavoured to avoid sharing my opinion unless I was explicitly asked for it. For example, a number of times I was asked to compare my life and my education with life and education in Ermera vila and its environs. In such situations I endeavoured to follow Crang and Crook (2007) in deconstructing myths about Western society being a goal to which all societies should aspire. I would make it clear that I felt that there was a strength of community in Ermera vila and Ponilala that New Zealand and 
Australia, as 'capitalocentric economies' (Cameron \& Gibson-Graham, 2007), lacked, and that young adults like myself could easily feel isolated in these societies.

Taking an immersive approach led me to share numerous informal conversations with people in and outside Ermera subdistrict. It has not been easy to draw a clear line between informal interviews and informal conversations, as my approach to both was similar. It was based on listening, allowing plenty of room for the other person to talk, and asking for clarification when needed.

\section{SURVEYS}

A total of 120 students were surveyed from Mau-Kruma ${ }^{6}$ and Imacon Schools ${ }^{7}$ in August and September over five sessions.

Table 3: Number of Surveys by School

\begin{tabular}{|l|c|c|c|}
\hline School & Number of students & $\begin{array}{l}\text { Number of Social } \\
\text { Science students }\end{array}$ & $\begin{array}{l}\text { Number of Natural } \\
\text { Science students }\end{array}$ \\
\hline Mau-Kruma School & 68 & 37 & 31 \\
\hline Imacon School & 52 & 35 & 17 \\
\hline Total: & 120 & 72 & 48 \\
\hline
\end{tabular}

\section{SEMI-STRUCTURED INTERVIEWS}

I conducted semi-structured interviews with students, parents, teachers, school principals, foreign professionals, NGO workers, government officials and one former President and Prime Minister. Formal interviews enabled in-depth discussion of personal experience and discussion of education and livelihoods, while a semi-structured format allowed a balance to be struck between covering important known topics and exploring as yet unknown but

\footnotetext{
6 'Escola Secundária Gerál Helio Sanches Pina Mau-Kruma Ermera': the public senior secondary school in Ermera vila.

7 'Escola Secundária Catholica Maria Immaculada Conceição Ermera': the private Catholic secondary school in Ermera vila.
} 
important topics (Crang \& Cook, 2007). I interviewed all students and their parents at their houses, and occasionally at a neighbour's house, either on their veranda or in their living room, to facilitate a relaxed environment within participants' context (O'Leary, 2010).

Interviews with students ranged from less than ten minutes to 25 minutes, and those with parents generally took between ten minutes and 45 minutes. Longer conversations were up to two hours in length. In the case of more informal interviews, notes were taken from memory subsequent to the conversation and verified where needed.

\section{PARTICIPANT SELECTION}

I conducted a total of 33 interviews with eleven students, three teachers, nine parents, two teachers, the two school directors, and one foreign volunteer. I held more informal interviews with other adult professionals further afield in Gleno and Dili, including five professionals working in education and agriculture, one senior government official from the MoE and one public figure. I also conducted interviews in New Zealand and Australia when the opportunity arose.

While I spoke to the majority of participants in Ermera vila and Ponilala, interviews took place across five locations across two municipalities of Timor-Leste. I also conducted more informal interviews in Mirtutu and Gleno, the regional capital town of Ermera municipality, and in Dili, the capital of the nation.

I knew most of teenage interview participants already. Three girls were the nieces of two teachers I stayed with, all five of teenage boys were students from the Ponilala English course who often accompanied me back to Ermera vila after the lessons. All save one of the parent participants were introduced to me by a friend and teacher from Ponilala, and five of these parents had teenage children who I also interviewed.

I asked the two School Directors and three teachers who I had already met whether I could interview them, and I held more informal-style interviews with professionals in Gleno and Dili, as well as with the foreign volunteer in Mirtutu. 
Table 4: Interview Participants by Research Location

\begin{tabular}{|c|c|c|c|c|}
\hline Site & Location & Location type & Data collection & Population \\
\hline Ermera vila & $\begin{array}{l}\text { Ermera } \\
\text { subdistrict }\end{array}$ & $\begin{array}{l}\text { Semi-urban } \\
\text { (former district } \\
\text { capital) }\end{array}$ & $\begin{array}{l}\text { (120 surveys) } \\
3 \text { students } \\
2 \text { teachers } \\
2 \text { Principals }\end{array}$ & $\begin{array}{l}8,830 \\
\text { residents }^{8}\end{array}$ \\
\hline Ponilala & $\begin{array}{l}\text { Ermera } \\
\text { subdistrict }\end{array}$ & rural & $\begin{array}{l}8 \text { students } \\
9 \text { parents }\end{array}$ & 3,370 \\
\hline Mirtutu & $\begin{array}{l}\text { Ermera } \\
\text { subdistrict }\end{array}$ & rural & 1 foreign volunteer & 1,970 \\
\hline Gleno & $\begin{array}{l}\text { Border between } \\
\text { Ermera and } \\
\text { Railaco } \\
\text { subdistricts }\end{array}$ & $\begin{array}{l}\text { Semi-urban } \\
\text { (large } \\
\text { commercial hub) }\end{array}$ & 1 professional & 8,130 \\
\hline Dili & Dili municipality & urban & $\begin{array}{l}1 \text { NGO worker } \\
1 \text { teacher } \\
1 \text { academic/education } \\
\text { professional } \\
1 \text { education senior } \\
\text { official } \\
1 \text { public figure }\end{array}$ & 277,800 \\
\hline Wellington & New Zealand & urban & 1 NGO worker & \\
\hline Canberra & Australia & urban & 1 volunteer teacher & \\
\hline
\end{tabular}

\section{LIMITATIONS}

\section{NAVIGATING LANGUAGE}

While I invested in learning some basic Tetun in the three months prior to my fieldwork, my language skills were limited during the course of my stay. This meant that the interviews were not as in-depth as they would have been had I been fluent in Mambae ${ }^{9}$ or Tetun. On the other hand, audio recording interviews enabled me to listen to recordings and, as I kept learning Tetun after returning from fieldwork, allowed me to translate and analyse them

\footnotetext{
${ }^{8}$ General Directorate of Statistics, 2015; RDTL, $2016 \mathrm{~b}$.

${ }^{9}$ The major local language of Ermera district.
} 
myself after leaving the country. Watching news broadcasts from $\mathrm{GMN}^{10}$, a major media channel, on YouTube from December 2019 to May 2020 helped me to continue learning Tetun (as broadcasts were mainly in Tetun, along with some Portuguese and Indonesian) and kept me up-to-date on developments in the country.

Learning Tetun was an attempt to decolonise my research approach and orient it more towards participants. By including chapter summaries in Tetun (See Appendix 1) I hope that the gist of my research can be read not just by my university, but also by these participants. I could also be sure of what participants told me without their responses being mediated by a third party.

\section{NAVIGATING POWER}

My status as a foreigner accorded me various privileges, such as access to high-ranking members of the community, and officials in Dili.

While sexual harrassment was an unpleasant and ongoing challenge while living in Ermera vila, being female appeared to have its advantages. I slotted in fairly naturally to the role of an assistant, which I do not believe would have been as natural for a male foreign research student. It also allowed me to talk to teenage girls. I came to understand that as a single unmarried person (klosan), speaking to members of the opposite sex may not be socially appropriate. Teenage girls were less shy around a woman some seven to ten years their senior than they would be around a young man. In this way my gender was ideal, in that it allowed me to engage with both teenage boys and teenage girls, and as a 'teacher' this was socially acceptable.

Thus I was accorded many privileges as a malae, and being female enabled me to slip under the radar in other ways, assume the role of a teaching assistant without undermining male teachers' sense of authority, and talk to teenage girls and young women, which would not have been possible if I had been a male researcher.

\footnotetext{
${ }^{10}$ Portuguese: Grupo Média Nacional.
} 


\section{RESEARCH INTEGRITY}

\section{ETHICAL REQUIREMENTS AND CONSIDERATIONS}

\section{University ethics requirements}

I went through the Victoria University Human Ethics process, which required me to have all interview and survey participants sign a consent form (see Appendix 2 for information and consent forms). I felt that this would ensure participants had ample opportunity to withdraw from the interview if they were not totally comfortable with participating, and it would give me a degree of professionality in the field. However, in practice the participants were generally restless during this stage and did not seem to see the point of going through the consent form given they had already made it clear that they consented to be interviewed. Furthermore, some parents couldn't read and write, and in these cases my approach caused participants discomfort, and was ill-fitted to the context. I concluded that it would have been more appropriate to obtain and record participants' verbal consent prior to the interview, particularly in the case of students and their parents (see also Jones, 2012, p. 35; Howson, 2015, p. 49).

\section{Obtaining permission to conduct research in Ermera district}

In February 2019, I asked the two Directors of Mau-Kruma and Imacon Schools whether I could come and volunteer for a month or so as a teaching assistant over the JuneSeptember period. Both assented, and I drafted a permission letter for both to sign in English and Tetun (see Appendix 3).

Prior to travelling to Ermera vila I obtained consent from the government to conduct research in Ermera municipality (Appendix 3). Giving the MoE a drafted permission letter in English and Tetun, along with supporting documentation from my university, expedited the process. Upon receiving the permission letter, I provided a copy of to both school directors. Upon arriving in Ermera vila I was introduced to the xefi (chief; leader) of Ermera vila, and off the bat I asked permission to conduct research in the area. He assented readily and did not seem too interested in or concerned by my activities. 


\section{CONDUCTING THE SURVEYS}

I showed the survey information sheets, consent forms and questionnaire page (see Appendix 4) to the two principals at the school prior to conducting the surveys, to ensure they knew the purpose of the surveys and were comfortable with me conducting them.

At each school, I engaged the help of a teenage student I had already met. One was in Grade 11 at Mau-Kruma school, and occupied leadership positions at the school, and the other who attended Grade 12 at Imacon school. Both were outgoing and enthusiastic about learning English. Their help with surveys was invaluable, as the students in the five sessions were markedly more comfortable asking a fellow student to clarify information than asking a foreign outsider, and their help in distributing and collecting forms made the sessions quicker and easier. On completion of the surveys I gave each student a certificate outlining their contribution to the research and the skills they had exercised and a small payment to recognise their work (see Appendix 5).

In each session I would introduce myself, explain my research topic, and make it clear that students did not have to participate if they did not want to. Myself and the assistant would distribute the information sheets, clarifying that students could take it away with them after the survey. We would allow for reading time and check whether they would still like to participate in the survey and then distribute and collect the consent forms. We would explain each of the ten survey questions, then distribute the survey sheets. ${ }^{11}$ I delivered an individual summary to each student showing their survey results within two weeks of the session, with my phone number in case they wished to withdraw from the survey or change their answers.

I aimed to find roughly equal numbers of Social Science and Natural Science Grade 12 students to take the survey. This took four survey sessions in total. In addition, I made a mistake with the Social Science survey at Mau-Kruma School, accidentally surveying a Social

\footnotetext{
${ }^{11}$ A couple of students in one session decided not to complete the survey, which I took as an encouraging sign that these students at least had not felt obliged to participate.
} 
Science rather than a Natural Science class. ${ }^{12}$ This error did afford valuable insights ${ }^{13}$ into the mutability of students' answers.

\section{ANONYMITY OF INTERVIEW PARTICIPANTS}

Development researchers are generally expected to determine whether or not participants wish to keep their identities private, and, if they do, do their best to respect that decision (Scheyvens et. al., 2003, p.143; Tilley \& Woodthorpe, 2011). I gave all participants the option of anonymity. While students and parents appeared very open to me using their names in my research I decided not to risk disclosing the identities of people who may have shared personal information with me, for example on their dreams and desires. However, I have named all participants in the Acknowledgements in recognition of their time and contribution.

\section{REFLECTION ON FIELDWORK AND METHODS: CONFRONTATIONAL CONTEXT}

Although I endeavoured to establish an 'authentic and critical foundation' for the 'subjective and inter-subjective' insights I gained from data (Dowling, 2010), I remained painfully aware of my lack of understanding of what it was like for teenage students attending school in Ermera. I became increasingly aware in the later stages of my research and as I began to write my results of the stark mismatch between the lives of students and parents I met and families who looked after me and my own life. This feeling, which became progressively visceral, started with reading about the Indonesian occupation as a background to the research site. Later it was compounded by the occasional references of those I met to the occupation under Indonesia. The contrast became wider as I came to realise that I could not possibly understand what it was like to grow up in a newly independent, still unstable country, survive on very simple food or go hungry for periods of time, see my parents work

\footnotetext{
${ }^{12}$ None of the students or my research assistant said anything about this obvious error, possibly due to my malae status, or the fact that I was seen as a teacher due to my assistance in English classes.

${ }^{13}$ Other than the names and genders the students had recorded, there was variation across all other answers. Students might give different responses for future plans, place of residence, birthplace, favourite subjects, weekly chores or parents' livelihoods. This suggested that I should be wary of making firm conclusions based on survey data. After realising my mistake, I found students who had taken the survey twice, apologised, and identified which survey they would like me to use.
} 
hard in their garden for barely any money, without the access to good healthcare and be at risk of contracting preventable diseases, and lastly, without access to high quality educational options.

The first time this hit home was when a businessman told me that:

'...Generally, families [in Ermera] live in pretty deep poverty. Students see the drudgery of their parents' lives and want to get as far away from it as possible' (interview, 25/7/2019, Gleno).

As I finished my fieldwork, my awareness of my myriad privileges compared to the subject matter of my research intensified. How could I possibly gain worthwhile insights into the context and the lives of those who faced challenges I would never have to deal with? I felt guilty, embarrassed, sad and angry that my privileges had allowed me to conduct research in place of young adults from the communities I was examining, who knew their context and its challenges much better than I ever could. They were the experts of their context; I was not.

I did not attempt to distance myself from these emotions, as I felt it was more respectful and authentic to keep them in mind as I analysed the broad data and range of perspectives gathered during fieldwork. These emotions helped to mitigate my desire to interpret and extrapolate based on this data past what was absolutely necessary, as they reminded me of the limits to my perspective as a white researcher in an indigenous context (Smith, 2012).

\section{CONCLUSION}

In this chapter I have established the epistemological and conceptual foundations of the research, the methods used, and covered key issues arising from the data collection process. I will now turn to education and livelihood realities in Timor-Leste, providing a background to my findings, which are presented in the three subsequent chapters. 


\section{Chapter 4: A Background to Education and Livelihoods in Timor-Leste}

Timor-Leste has undergone much change since gaining independence in 2002. This chapter will provide a brief overview of the country's demography and history, before focusing on developments in education over the past twenty years. It will then provide an overview of employment and livelihoods within the economy, with particular reference to agriculture.

\section{BACKGROUND}

Timor-Leste is a small, mountainous country which covers one half of an island lying within the eastern reach of the Indonesian archipelago (Fox, 2001; Fry, 2014). Its population of 1.3 million live in its 15,000 square kilometres, which is divided into thirteen districts. Around 280,000 people live in Dili, the coastal capital (General Directorate of Statistics Timor-Leste, 2015).

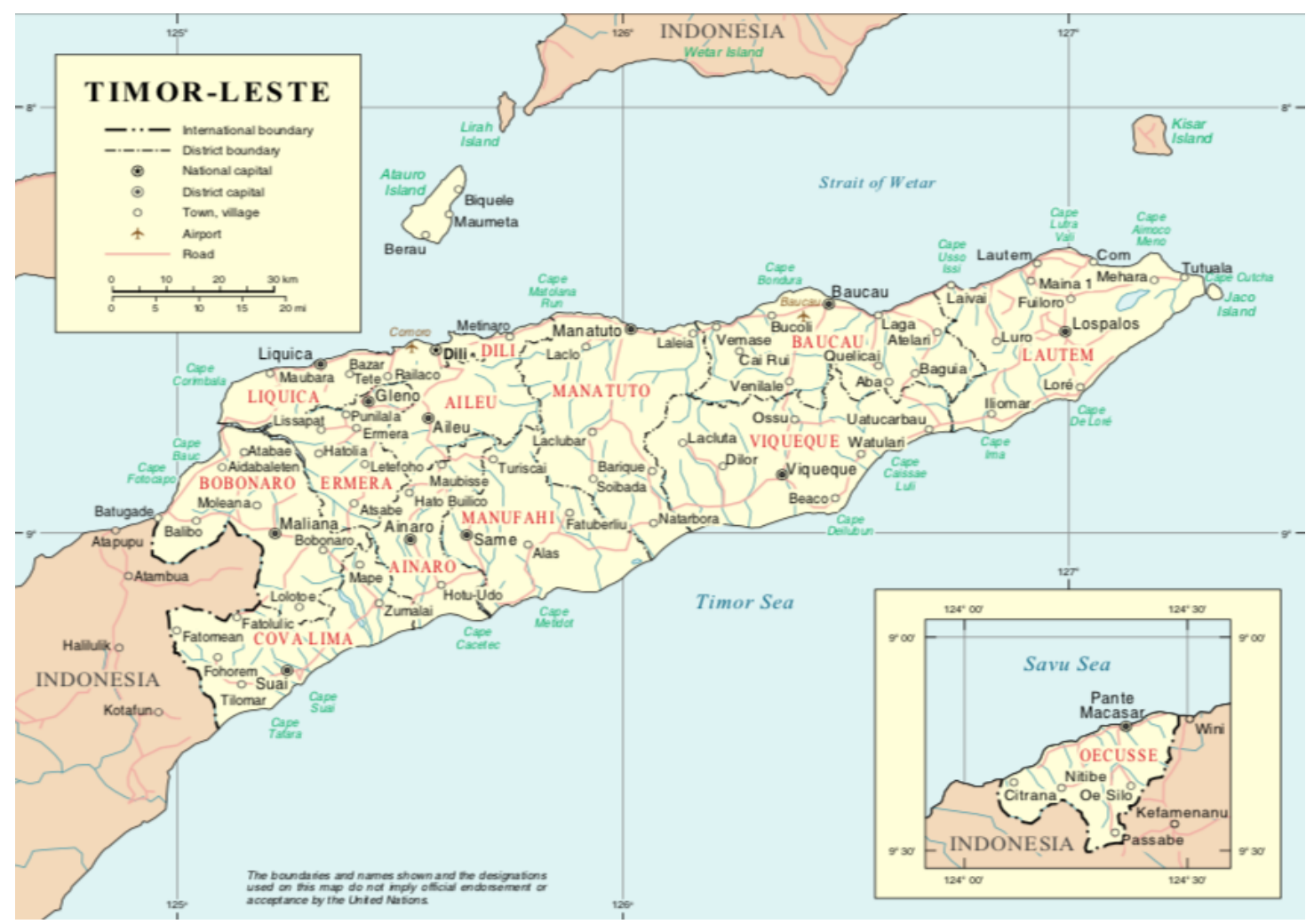

Map of Timor-Leste, including the Oecusse enclave. Source: United Nations Dept. of Field Support: Cartographic Section, 2011. 


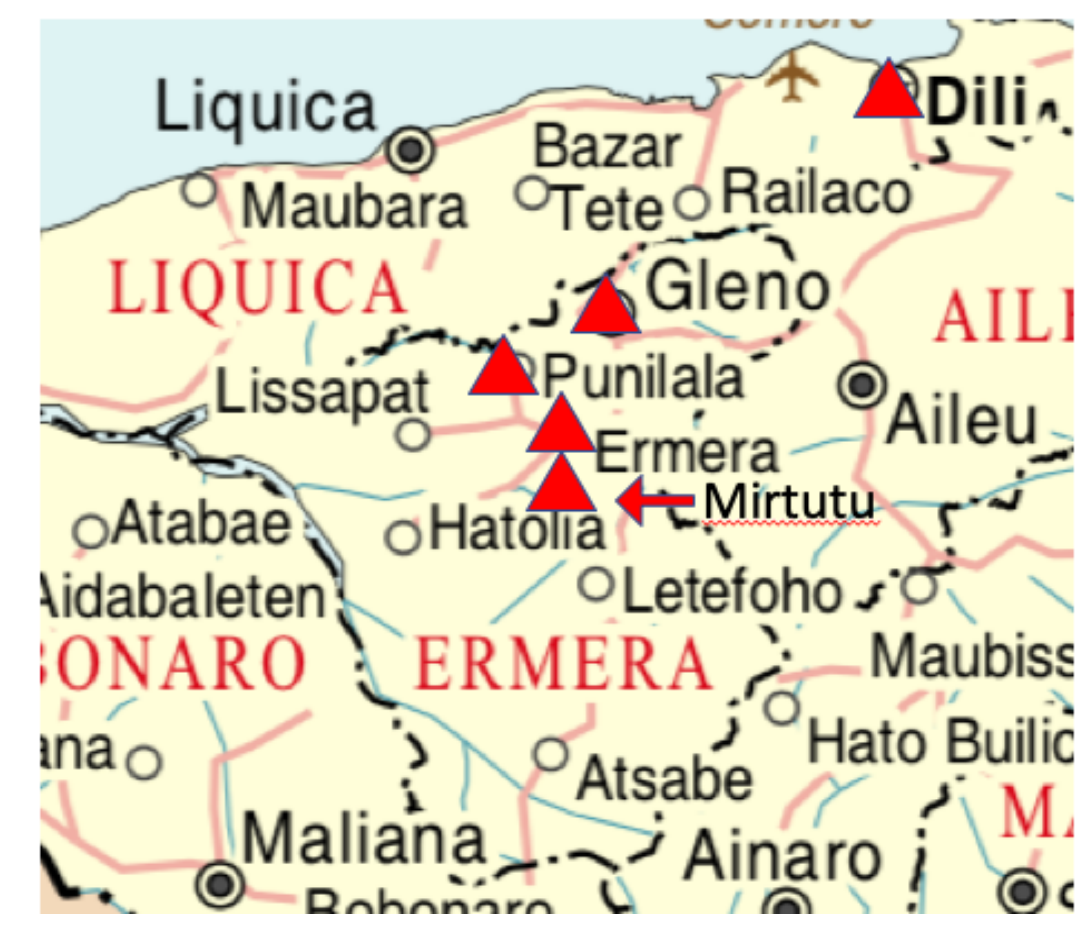

Section of previous map, with key research sites marked.

\section{HISTORY}

The pre-colonial history of the island of Timor remains relatively obscure (Cribb, 2006). It is believed that many now living on the island have Austroloid and Melanesian ancestors who arrived over 40,000 years ago, with a more recent influx of proto-Malay migrants from South China (now Northern Vietnam) around 5,000 years ago. Distinctive cultures have developed in the past 4,000 years, with fishing and farming of fruits, nuts, and various cereals such as rice and sugarcane, and use of a gold coin currency from mountain deposits on the central northern coast (Fox, 2008, p. 120). Timor remained on the edge of the Indonesian commercial world, with its sandalwood resources traded to China and India by Chinese and Javanese traders in the fourteenth century and its people captured and sold as slaves in markets in the archipelago (Cribb, 2006). In the sixteenth century, Portuguese traders also arrived to pilfer sandalwood and beeswax (Fry, 2014; Peake, 2013, p. 12). Thus Timor appears to have had substantial contact with other regions, although not necessarily on an equal footing. 
Dutch and Portuguese forces battled for control over the island in the ensuing centuries, leading to the division of the island into East and West territories (Cribb, 2006; Fry, 2014; Peake, 2012). Although Portugal officially annexed the eastern half in 1702 (Fry, 2014), the newly named Portuguese Timor was not fully subjugated by Portugal until well into the twentieth century (Peake, 2013). Prior to this the Portuguese colonisers and the liurai (the kings of regional fiefdoms) had an ongoing struggle for control over different parts of the country. Portugal had established a port, Dili, but did not have firm control of the rest of the island.

After the 1942-1945 Japanese invasion, Western Timor became part of Indonesia, while East Timor remained a Portuguese colony until the fall of Salazar in Portugal in 1974 (Cribb, 2006). After a brief power struggle between emerging political parties, independence was declared in 1975, just days before an invasion by Indonesia. The ensuing twenty-four years were characterised by resistance by Timorese guerrilla fighters in the face of brutality and unspeakable human rights abuses, internal displacement, famine and further exploitation of the country's resources (Kammen, 2001). However, Indonesia also built much infrastructure, including schools. Media coverage of atrocities caused mounting international pressure in the 1990s and the United Nations (UN) finally began to intervene (Cribb, 2006). East Timorese citizens overwhelmingly voted for independence in a referendum overseen by the UN amid intimidation and manipulation by Indonesian militias. In retaliation, Indonesian military hacked and burned its way back across the border, leaving a decimated country to pick up the pieces (Fry, 2014; Kammen, 2001). Timor oan ${ }^{14}$ had finally gained their independence through unceasing resistance and at great personal cost.

After three years of interim governance by the United Nations Transitional Administration in East Timor (UNTAET), full independence was declared in 2002 and the Republika Demokrátika Timor-Leste (RDTL) was formally re-instated. Reconstruction efforts continued, with a large amount of foreign aid flowing into the fledgling democratic nation (De Almeida, 2015; Peake, 2013). Unresolved political tensions led to civil conflict from 2006 to 2009. This conflict was ostensibly fuelled by a bored, frustrated youth population (Peake, 2013),

\footnotetext{
${ }^{14}$ Timorese citizens, lit. 'children of Timor'.
} 
although ex-President and Prime Minister José Ramos Horta believes it was due to resentment caused by re-settlement patterns in Dili by different regional groups after 1999 (Interview, 6/8/2019, Dili). The UN returned in a peace-keeping capacity, before leaving again two years later (Fry, 2014; Peake, 2013).

Internal affairs have since been largely peaceful, barring small-scale conflict between martial arts groups and state budget-related political problems in 2017-2018, and most recently in 2020 (The Guardian, 2020). This political dysfunction compromises the country's economic health and has a substantial impact on ema iik $^{15}$, who are most vulnerable to economic downturns.

\section{LANGUAGES}

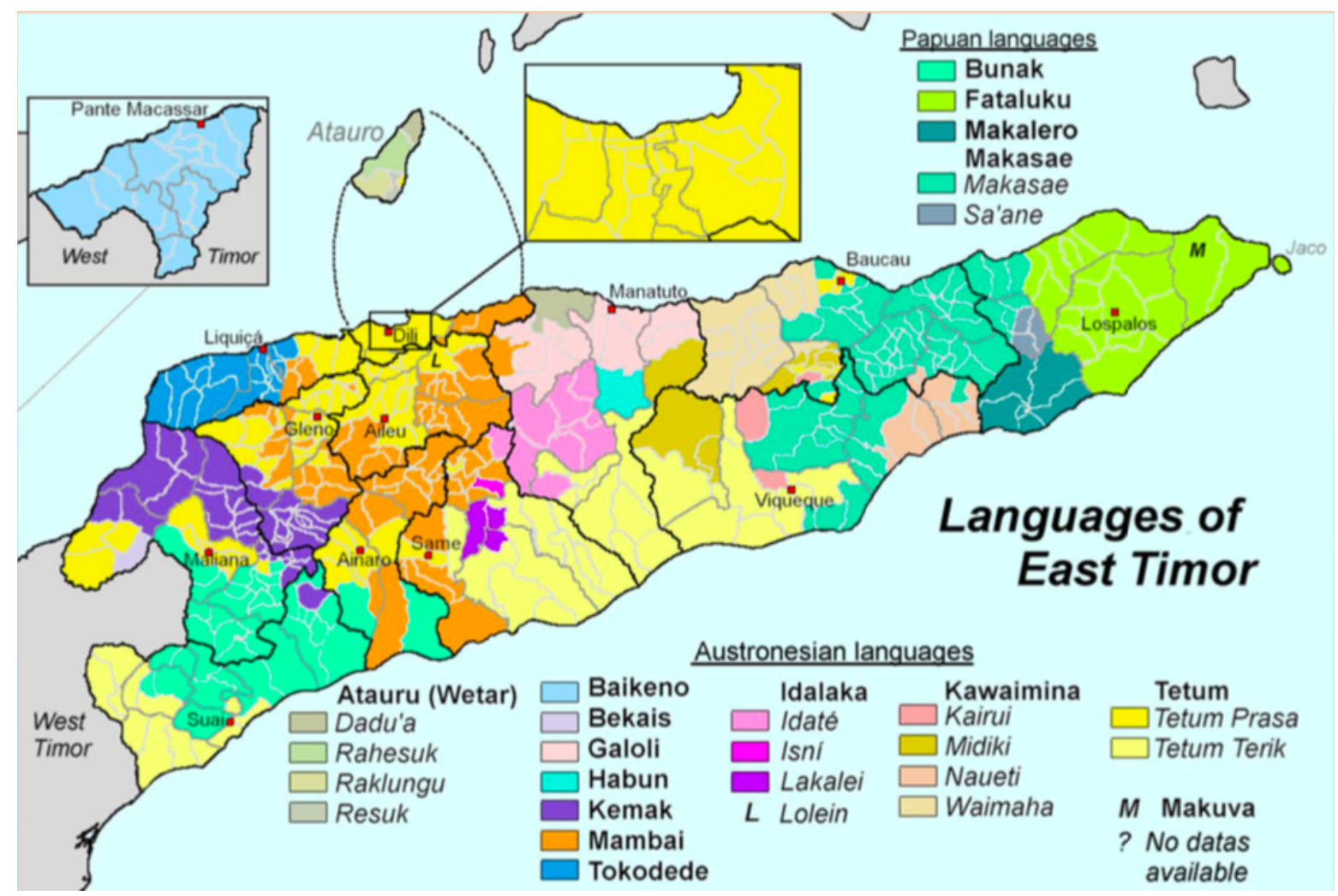

Map of linguistic regions in Timor-Leste. Source: Presentation by HE Dulce de Jesus Soares, 2016.

${ }^{15}$ Ordinary folk, lit. 'little people'. 
Many languages are spoken across the half-island. Tetun and Portuguese are its two official languages, with Bahasa and English considered working languages. Tetun is an indigenous lingua franca (Cribb, 2006) but contains a substantial amount of Portuguese. De Jesus Soares (2016) cites fourteen languages and sixteen dialects across the thirteen districts, although the number varies within academic research. ${ }^{16}$ Some languages such as Mambae, which is spoken across Ermera, Ainaro and Manufahi municipalities, encompass several dialects. Children grow up in a multilingual environment and might speak several languages in addition to their mother tongue. Students learn in Tetun at primary level; Portuguese in secondary school; and may speak another local language, or Indonesian, a school subject and a source of pop culture (World Bank, 2013; Peake, 2013).

Viewing Portuguese and Indonesian as languages of colonial oppression ignores the way they have been repurposed and assumed new roles within Timorese society as these powers have invaded and retreated, and the political landscape has evolved. Portuguese became the language of resistance in the Indonesian occupation as Indonesian soldiers could not understand it. Indonesian is the language of the marketplace ${ }^{17}$ and the language of soap operas on television, which teenagers watch avidly (Peake, 2013; personal observations). I observed that many teenagers and adults had Facebook accounts which were set to Indonesian. Linguistic complexity is therefore part of Timor-Leste's sociopolitical landscape, including the education sector.

\footnotetext{
${ }^{16}$ Fry (2014) cites 19 different languages and 16 different dialects; Peake (2013, p. 3) cites 20 different languages; Quinn (2013) cites over 24 national and other languages.

${ }^{17}$ Indonesian numbers are still used for everyday goods and services, from fruit and vegetables to taxi fares across Timor-Leste.
} 


\section{THE EDUCATION SYSTEM}

Over the past fifty years, education in Timor-Leste has been characterised by many shifts in control brought by colonisation, invading forces and international organisations.

\section{EDUCATION UNDER PORTUGAL AND INDONESIA}

The Portuguese colonial administration did little to develop formal education in the country. Only $0.5 \%$ of the indigenous population was considered civilizado (able to speak and write in Portuguese) (Cribb, 2006). The administration struggled to fund themselves and little money was put towards schooling (Cribb, 2006; Peake, 2013). All languages other than Portuguese were banned in the classroom, which was a particular disadvantage for children from rural families, who generally spoke no Portuguese at home (Hill, n. d., p. 7). The few Timorese citizens who did obtain a formal Western education were often mestizo, having a Portuguese family member. Successful students were often drawn overseas, such as to the colonial centre of Lisbon, to continue their education (Peake, 2013). According to Hill (2007, pp. 3-4):

'The 'hidden curriculum' of Portuguese education was that one could not be a civilized person without being schooled in Portuguese language, literature and to some extent other Western classics. Under an 'assimilationist' philosophy of colonization, education, as well as the Catholic Church, played a role in deciding who could become a citizen. Many of the older generation of Timorese were educated under this system and some still hold these beliefs.'

However, the education attained by the small minority of mestizo youth profoundly affected the country: many leaders of the 1975 FRETELIN party ${ }^{18}$ had been educated overseas, and their awarness of independence movements in other Portuguese colonies spurred their political mobilization to achieve independence (Peake, 2013). In fact, FRETELIN ran literacy programs in 1974-1975 which were based on the ideas of Paulo Freire (Bassarewan, 2005;

\footnotetext{
${ }^{18}$ The Revolutionary Front for an Independent East Timor (Portuguese: Frente Revolucionária de Timor-Leste Independente).
} 
Hill, 2002). Many Portuguese-educated Timorese university students also fanned out across rural villages to raise political awareness and some ran cooperative programmes on literacy, agriculture and community health. Some of these initiatives continued into the $1980 \mathrm{~s}$ despite the start of the Indonesian occupation (Batterbury et. al., 2015).

The Indonesian government, on the other hand, made an effort to universalise education within the annexed country. Education became accessible to the majority as the Indonesian administration provided school places at primary, secondary and tertiary level at relatively affordable cost (Hill, 2007). Enrolment rates rose dramatically, the gender gap started to close, and by 1995 every village had a primary school (UNDP, 2002). However, in 1995 only slightly under half of 15-19 year olds had completed their primary education or gone further (Justino, et. al., 2011, p. 10), ${ }^{19}$ and very few had completed secondary education or above (Jones, 2001, p. 257). Literacy had only risen above $50 \%$ for those aged $15-24$. This is perhaps not surprising, as students were taught in Indonesian, with Tetun and local languages banned ${ }^{20}$ as they had been under Portugal (Hill, n.d., p. 7). School enrolment continued to increase (Jones, 2001, p. 256), but the expansion of education was not disinterested: the Indonesian administration pushed its Pancasilia system onto Timorese students in an attempt to 'socialize' them into being good Indonesian citizens and assimilate them into the rest of the archipelago (Hill, 2007, pp. 3-4). Helen Hill views this as an unwritten ideology, or 'hidden curriculum', to use the words of Illich and Reimer (Hill, 2007, p. 1). In particular the Pancasilia system includes principles such as belief in one God, humanitarianism, national unity and social justice (Hill, 2007). Capelo \& Cabrito (2015) criticise the Indonesian system of education for being superficial and staffed by unqualified teachers, although it is worth noting that both these researchers are from a Portuguese university.

\footnotetext{
${ }^{19}$ Reasons for this included infrastructure and material shortages, inability to pay school-related expenses and fear.

${ }^{20}$ Except in Catholic churches, where Tetun was allowed to be spoken.
} 
Both Indonesian and Portuguese systems contained the same message for students: work in the rural areas was undesirable, Timorese culture was inferior and everybody should want to be a public servant in the capital (Hill, 2007, p. 4; Hill, n.d., pp. 11-12). Only outside knowledge was valued, and the brightest students were often siphoned away to study or work in the colonial centres of Lisbon and Jakarta. The traditional knowledge of parents and grandparents in food production, cuisine, animal rearing, medicinal plants, or language and culture were dismissed as 'not worth having' (Hill, 2007, p. 4).

Under these two foreign powers most Timorese people were uncertain about the purpose of education: whether it was for the 'improvement of life in the village, bringing skills, new knowledge, techniques and investment into the local area to improve the quality of life, or whether it was to help a few bright students get out of the village, get good jobs elsewhere and send money back to their families' (Hill, 2017, p. 11). My findings suggest that this ambivalence has persisted into the present day, as I will discuss in following chapters.

\section{ENGAGEMENT WITH INTERNATIONAL EDUCATION POLICY}

In the late twentieth century, Timor-Leste was suffering under Indonesian control and consequently missed out on global efforts to promote education development. By the time the country gained independence, the neoliberal agenda, which is characterised by relying on the market to allocate jobs, was in full swing (Hill, 2005). However, Timor-Leste adopted the MDGs after gaining independence (Hill, 2007), and later had a more active role in shaping some of the SDGs (Hill, 2017).

In 1999 there was a Melbourne conference on Strategic Development Planning for an Independent East Timor (Hill, 2017), which concluded that education was a key sector in the country's social and economic transformation, and that it was vital that the schooling system and educational opportunities could be flexible enough to boost equity and participation (Millo and Barnett, 2003). 


\section{THE GOVERNMENTAL VISION FOR EDUCATION IN TIMOR-LESTE}

The Constitution of Timor-Leste recognises the right of every citizen to education and culture, and it is the duty of the government to provide free, universal basic education to the best of its ability. (Constituent Assembly East Timor, 2002).

Former Prime Minister Mari Alkatiri has stated that the most valuable resource of TimorLeste is its people, and their capabilities, their skills, their motivation, and their 'willingness to develop their minds', and as such education is an important means of providing people with skills and increasing their productive capacity and their ability to innovate (Hill, 2007, p. 10).

The Ministry of Education, Youth and Sports now has responsibility for the education system at all levels except tertiary level which is managed by the Ministry of Higher Education, Science and Culture (Hill, 2017). Vocational training falls under a separate Ministry to general education, instead managed by the The Secretariat of State for Vocational Training Policy and Employment (Secretaria de Estado Para a Politica da Formação Professional e Emprego, or SEPFOPE) (Hill, 2017, p. 6). Faith-based organisations and entrepreneurs in the private sector also run schools from preschool to tertiary level (World Bank, 2013).

\section{TWENTY YEARS OF CHANGE}

There has been massive change to the delivery of education since the end of the Indonesian occupation in 1999, and over the past twenty years the education system has been rebuilt more or less from scratch. It is within this context that deficiencies and challenges to the delivery of education must be considered.

The retreating Indonesian military razed virtually all infrastructure, including school buildings and power grids (Hill, 2005; Hill, 2007). The country also lost almost all its qualified workforce in all sectors, including in education (Almeida et. al., 2014). This effectively destroyed the entire education system. In the same year, UNTAET took over as an interim civil administration, under which schools were rebuilt and reopened as part of massive reconstruction across the country. Both UNTAET and the East Timorese leadership 
prioritised education, and an enthusiasm for education was demonstrated by a higher number of students attending primary school than before the referendum period, 'often being taught by volunteer teachers in burned-out buildings or open spaces' (Jones, 2001, p. 260). From 2002 the newly independent government has continued to build schools to deliver education to the fast-growing youth population.

Overseas educational aid has played a significant role in the post-independence development of Timor-Leste's education system. UNTAET fully financed the country during its thirty-two months of governance. The new country remained in great need of financial support, and it has received a large amount of international aid, mainly from Australia and Portugal, who remain the country's largest foreign donors, especially for education (De Almeida, 2015; Justino et. al., 2011).

According to Dr Ramos Horta, former and President and Prime Minister of Timor-Leste, there has been huge progress in the past twenty years (Interview, 6/8/2019, Dili). In 1999 there were just nineteen doctors in the whole country, and the Ministry of Finance was entirely run by foreigners, whereas now it is almost completely staffed by Timorese nationals, and other financial institutions such as banks are the same. 40,000 people work for the civil service: 'These staff members are Timorese with degrees and jobs.' In the past ten years alone roughly 1,000 schools have been built, and there have been 40,000 university graduations. Dr Ramos Horta emphasised that overall there has been a lot of success.

According to Mr Julio Soares Madeira, a teacher at Mau-Kruma school who has been teaching since the 1999 referendum and is a former School Director of NCES ${ }^{21}$ in Gleno, many more students are now enrolled at school in Ermera district compared to twenty years ago. However, development of education has been hampered by the constant changes in government, and the succession of different Education Ministers. Sometimes one Minister or government has made a positive change, only for it to be undone after a subsequent

\footnotetext{
21 'Escola Nino Konis Santana de Gleno': the large public senior secondary school in the regional capital of Ermera district.
} 
change in leadership. 'We - the students and teachers - are the ones who suffer from these changes' (Interview, 3/9/2019, Ermera vila).

A senior English teacher in Dili emphasized the disruption caused by the civil conflict that began in 2006. The technical college he was teaching at had opened in 1986, been burned down in 1999, and then again in 2006. 'There were no desks, no tables, nothing' (Interview, $23 / 6 / 2019$, Dili). It was rebuilt for a third time in 2008 . In the early 2000 s the students were very committed to learning and dedicated to their study, although their progress toward attaining qualifications was slow, perhaps because the country was still in the process of rebuilding its educational institutions. After the crisis, he observed that the students' motivation was lower, and he was puzzled as to why.

Between 2010 and 2015 a new General Secondary Education (GSE) curriculum was developed and implemented under an agreement between the Timorese Government and a Portuguese university. The restructure divided the curriculum into two paths: Sciences and Technology, and Social Sciences and Humanities (Lucas et. al., 2015). Fourteen subjects were developed under the curriculum reform, including eight core subjects (Tetum, Portuguese, English, Indonesian, Citizenship and Social Development, Multimedia Technologies, Religion and Moral Education, and Physical Education and Sport, the last of which is dropped in the final year) (Burns, 2017, p. 42). Biology, Geology, Chemistry, Physics and Mathematics are part of the Natural Science stream, while the Social Science stream includes History, Geography, Sociology, Economics and Quantitative Methods and Themes of Literature and Culture. 
Table 5: Core Subjects Offered at Secondary Level

\begin{tabular}{lllll}
\hline \multicolumn{1}{c}{ Subjects } & Code & Subjects & Code & \multicolumn{1}{c}{ Subjects } \\
\hline $\begin{array}{l}\text { Biology } \\
\text { Citizenship and }\end{array}$ & Bio & Geology & Geo & Chemistry \\
$\begin{array}{l}\text { Social Develop- } \\
\text { ment }\end{array}$ & & History & Hist & Sociology \\
$\begin{array}{l}\text { Economics and } \\
\text { Quantitative }\end{array}$ & EQM & English & Eng & $\begin{array}{l}\text { Multimedia } \\
\text { Technologies }\end{array}$ \\
$\begin{array}{l}\text { Methods } \\
\text { Physics }\end{array}$ & & & & \\
& Phys & Mathematics & Math & $\begin{array}{l}\text { Themes of } \\
\text { Literature and }\end{array}$ \\
& & & & Culture \\
Geography & Geo & Portuguese & Pt & \\
\hline
\end{tabular}

Source: Capelo \& Cabrita, 2015, p. 134.

\section{DECOLONISING EDUCATION}

The new country's limited resources in the post-independence period has necessitated its reliance on money and support from the latter country and its former colonisers.

Portuguese textbooks continue to be used at secondary level, as well as Indonesian ones to a more limited degree (personal observation, Ermera vila, and Becora, Dili). Despite this challenge, the government has taken steps to decolonise the education system.

In the first years of reconstruction, Indonesian textbooks were initially reprinted with an endorsement from Xanana Gusmão (a national leader and wartime hero) as schools were rebuilt (Hill, 2007). However, from the early 2000s, government education policy included the phasing out of Indonesian language as the language of the curriculum (Interview with secondary school teacher, 17/9/2019, Ermera vila). Textbooks printed in Portugal replaced the existing Indonesian textbooks. However, remnants of the Indonesian education system persist in the present-day schools. The Indonesian terms 'SD' (primary school), 'SMP' (presecondary school), and 'SMA' (senior secondary school) are still used just as much as their Tetun and Portuguese equivalents (Personal observation, Ermera and Dili). 
The 2010-2015 curriculum restructure exemplifies the ongoing influence of Portugal upon the education sector of its former colony. While Portuguese academics view this restructure as the implementation of an 'original curriculum' reflecting the social, religious and ethnic diversity of Timor-Leste' (Almeida et. al., 2014, p. 666), under an agreement between the Portuguese and Timorese governments the design, development and implementation of the restructure was managed by a Portuguese university. A key purpose of the restructure was to 'support and strengthen Portuguese as the instruction language' (Lucas, et. al., 2015, p. 734). The final stages involved Portuguese teachers providing scientific and pedagogical training to Timorese teachers, as well as Timorese teachers being sent to the University of Aveiro for short periods to receive didactic and scientific training (Almeida et. al., 2014). ${ }^{22}$ This is an example of the choice faced by many poor post-colonial states: either accept help that serves the agenda of a former coloniser, or receive no support at all (following Escobar, 1995). It is also an example of Western scientific-style education being established in a Pacific country in which it may not be suitable (following Coxon, 2020).

By 2016 after a new curriculum for basic education (up to Grade 9) was implemented under Vice-Minister Dulce de Jesus which instated Tetun as the language of instruction and for initial literacy, with Portuguese being introduced in Grade 4 (Hill, 2016; De Jesus Soares, 2016; FOKUPERS, 2018). Portuguese then becomes the designated language of instruction at pre-secondary and senior secondary level. There was some contention in 2018 when civil society bodies expressed their concern over government plans to demote Tetun to an auxiliary status below Portuguese (FOKUPERS, 2018). The government also ran a 2012-2016 pilot program to test the feasibility of teaching in mother tongues at lower primary school level. (RDTL, 2017). Although I have not found mentions of further efforts in this direction, it seems to show an openness of the RDTL towards ways to decolonise on linguistic lines. Nevertheless, tension over the status of Portuguese and Tetun is clearly an ongoing issue: this was confirmed by my interviews and informal conversations in Ermera and Dili.

\footnotetext{
${ }^{22}$ Timorese teachers being sent to Portugal for training continues in the present day, according to informal conversations with a teacher and an NGO staff members in Dili (January and June, 2019).
} 
More recent efforts to decolonise the curriculum and align it more closely with the country's economy has included the formulation of a school garden program based on Permaculture principles, in consultation with the Permaculture Organisation in Timor-Leste (PERMATIL). Under Minister for Education Dulce de Jesus, a national-level education team is overseeing the introduction of these gardens at primary and pre-secondary level. (Hill, 2016). Permaculture and agroecology principles are taught in the early years, and from Grade 4 students learn about cuisine and nutrition. The program aims to bolster the school lunches program by allowing students to learn and grow food for the program at school (Lemos, 2016; Hill, 2016; RDTL, 2019).

A participatory science program called 'Timorpratika' has also been developed which teaches students principles of physics, chemistry and biology using readily available materials for experiments in order to link student learning more fully with their physical surroundings. 'Timorpratika' is the brainchild of $\mathrm{SESIM}^{23}$, a semi-governmental organisation linked to the MoE. In recent years SESIM has supported a team of university students, the Estudante Hanorin Pratika Agora ('Students Teaching Practice Now') group, to present practical science and mathematics activities to secondary school students at a number of locations around Timor-Leste (Gabrielson, 2018). While the reforms implemented by SESIM only go to Grade 9 at present, they have the potential to equip students with 'many of the life skills needed to address Timor-Leste's major problems such as soil, water, energy, nutrition, sanitation and health as well as giving them improved language skills and the ability to grow food' (Hill, 2016, p. 2).

Schools observe numerous national holidays, such as Popular Consultation Day (30 August), Independence Restoration Day (20 May), Proclamation of Independence Day (28 November), and the arrival of INTERFET ${ }^{24}$ (20 September) (Personal observation, Ermera vila). The observation of these dates serves to teach and remind students of their parents' and grandparents' struggle to free the country in which they now live.

\footnotetext{
${ }^{23}$ The Centre for the Study of Science and Mathematics (Tetun: Sentru Estudu Siensia no Matematika).

${ }^{24}$ The International Force East Timor, the Australia-led multinational peacemaking taskforce.
} 
However, the legacy of Indonesian and Portuguese education systems can pose a significant impediment to decolonisation efforts. According to Hill (2016), the devaluation of indigenous and traditional knowledge is two-fold. First, these indigenous and traditional knowledges have been looked down on by educated elites throughout Portuguese and Indonesian times (Hill, 2007; Hill, 2017). Second, parents, particularly rural parents, have unrealistic expectations of what school can do for their children, which further devalues their own knowledge and skills:

'People who do not have education themselves often believe that something magical takes place simply by sitting in a classroom and think it's better for their children to be in there learning about the history of Portugal or Indonesia than learning how to grow food, build houses or make tais ${ }^{25}$ from their parents and grandparents.' (Hill, n.d., pp. 6-7).

Hill sees this faith in schooling as an example of the 'custodial' role of education at work. Through this 'colonisation of the mind' the influence of the Portuguese and Indonesian systems remains very much alive. It is vital for local culture, knowledge and skills to be recognised and valued to unseat these oppressive educational-epistemic structures.

\section{CHALLENGES TO THE EFFECTIVE DELIVERY OF EDUCATION}

The deficiencies of the country's education system are well-documented. Challenges to the universal, effective delivery of education in present-day Timor-Leste a high drop-out rate; include teacher and student absenteeism; long distances to school; an overemphasis on rote learning; a shortage of resources such as textbooks; lack of water and sanitation facilities. The multiplicity of languages, a key demographic feature of the island, also creates challenges for implementing a national education system that enables all students to learn effectively (World Bank, 2013). The swelling number of school-age children has put pressure on school infrastructure, with more schools and buildings needing to be built, and chairs, tables and textbooks to meet demand (World Bank, 2013).

\footnotetext{
${ }^{25}$ The traditional cloth weaved by Timorese women.
} 
Importantly, a former Prime Minister has pointed to one of the main deficiencies of the Timorese education system as being the 'major disconnect between what is taught in school and its application in daily life' (Araujo, 2016).

There is a significant difference in infrastructure, resources and accessibility between schools in the capital city and large regional towns near Dili, and schools in remote rural areas (World Bank, 2013). It is common for children to move in with relatives in larger towns, and even to Dili, in order to attend larger, better-equipped schools (Batterbury, 2015). Urban migration increases within higher education, as most tertiary institutions are in Dili. Education therefore plays a sizable role in rural-urban migration, "drawing the most creative young people away from the areas in which they could make the most difference with the application of their skills' (Hill, 2017, p. 6).

\section{BASIC EDUCATION: THE PRIORITY OF THE RDTL}

The priority of the RDTL is to provide universal basic education in order to improve outcomes across the country, with secondary education remaining a secondary concern (World Bank, 2013; interview with senior MoE official, 19/9/2019, Dili). This focus is characteristic of MDGs-era global education policy (McGrath, 2016), and a logical policy step for a country developing a still-new education system. However, as Jones (2001) points out, in order to improve education at primary level it is important to have competent, qualified teachers. This is not possible without future teachers receiving a decent secondary school education and, ideally, teaching programmes at tertiary level. Secondary education is also a key stepping stone towards entering the workforce. 


\section{THE PATH FROM EDUCATION TO EMPLOYMENT}

According to research conducted by both Hill and Cryan, the pathway from education to work is not necessarily clear or well-understood by students and their families. In 2007, Hill contended that Timorese families do not have a clear understanding of the purpose of education:

'It is very important that parents and other relatives have a good opportunity to understand what schooling is for. Should schools teach skills that improve life in the village? ... Can they also provide classes for those adults who missed out on learning how to read and write? ... People are still afraid of taking initiative and fear they are acting 'outside the regulations' as they were in Indonesian times' (p. 10).

Five years later, in a study of 1200 people living in rural areas conducted by an NGO, households universally reported schooling to be a high priority, which was complicated by families increasingly being in need of money due to modernization and inflation (Cryan, 2012). Cryan's findings indicate that the rural residents she interviewed believed that education would lead to young people getting jobs that would provide the household with more money.

Hill highlights a disjuncture between the jobs available in the country and the work that students want to do. Bright, hardworking students do not usually wish to move into private sector work, even though the RDTL wants to build a vibrant private sector. Instead they tend to seek work in the public service or in the foreign development assistance sector, despite few jobs being available in these organisations (Hill, 2017).

Under the Indonesian occupation agriculture was 'generally carried out by those who failed in the schooling system', accounting for its very low productivity, and the low status of farming has persisted due to 'indoctrination' in schools regarding its worth relative to formal employment (Hill, 2005, p. 105). This jeopardises the future of agriculture, as the sector needs farmers who are 'innovative, curious, intelligent, risk-taking and have some scientific knowledge' (Hill, n. d., p. 12). 
Hill argues that developing some form of improved education for agriculture and rural livelihoods is particularly important. While the government has invested considerably in the Agricultural Faculty of the national public university $(\mathrm{UNTL})^{26}$, as stated above most graduates look for jobs in the government or in international aid organisations rather than in farming. There are significant cultural and class differences between these university graduates and farmers, so graduates from the agricultural high school tend to communicate better with farmers, and often find work as agricultural extension officers (Hill, 2007).

Hill (2017) belives that students would benefit from a greater awareness of where jobs might be available, which would be facilitated by a greater knowledge of the political economy and economic history of the country. More information and support by universities and technical-vocational institutions on students' options after study would help young people to engage with the work force and with their society more generally (Hill, 2017, pp. 38-39; Sanderson, 2001).

\section{TECHNICAL TRAINING SCHOOLS ACROSS THE COUNTRY, INCLUDING SOLS}

While the connection between education and employment is not concrete, vocational schools and technical training colleges (commonly referred to as tek voks) constitute a kind of half-way point between the two, and there are numerous of these across the country. These secondary-level vocational schools and tertiary institutions offer training on a range of areas, including agriculture, technical trades, engineering, hospitality, and tourism (interview with senior MoE official, 19/9/2019, Dili). Secondary level education is divided into Ensino Secondário Geral (GSE; General Secondary Schooling) and Ensino Secondário Técnico-Vocational (ESTV; Secondary Technical and Vocational Schooling) (Hill, 2017). There are technical training centres in Dili and in major regional hubs such as Gleno, Tibar and Baucau vila (Hill, 2017; Quefi, 2016). In 2016 there were 32 private and public ESTV schools across the country, including seven in Dili and five in Baucau vila (RDTL, 2016a). These include the Don Bosco Schools. I talked to an Australian retired teacher who has made annual trips to teach voluntarily in these Don Bosco Schools for many years. He told me that although students graduate with the practical skills to find immediate work, for example as

\footnotetext{
${ }^{26}$ Tetun: Universidade Nasionál Timór Lorosa'e.
} 
electricians, many still enrol at a university after graduation (Interview, 4/4/2019, Canberra). This suggests that these students do not value the practical skills they have gained as much as the university education that they subsequently pursue.

Science of Life Systems 24/7 (SOLS) centres are well-regarded English language training centres in the country which also offer other programs such as Information Technology and Financial Management (Rose, 2019). They are based on principles which include encouraging diligence, discipline, compassion and positive thinking. According to Rose (2019), most English speakers under thirty-five have had contact with the centres.

\section{EMPLOYMENT AND LIVELIHOODS IN TIMOR-LESTE}

Before exploring the ecology of livelihoods in Timor-Leste, it is necessary to examine what is meant by this term. A livelihood encompasses both formal waged work, such as office work and contract jobs, and informal work, such as selling surplus produce from a small farm at a market. Robert Chambers and Gordon Conway first defined the concept of 'sustainable livelihood' (Knutsson, 2006):

'A livelihood comprises the capabilities, assets (stores, resources, claims and access) and activities required for a means of living: a livelihood is sustainable which can cope with and recover from stress and shocks, maintain or enhance its capabilities and assets, and provide sustainable livelihood opportunities for the next generation; and which contributes net benefits to their livelihoods at the local and global levels and in the long and short term'. (Chambers \& Conway, 1991, p. 6)

This definition encompasses a quite broad range of activities, and so to gain a fuller understanding of livelihoods in Timor-Leste, the formal and informal sectors at national as well as local levels must be considered. 


\section{ECONOMY}

Timor-Leste is technically an oil-based economy, as the sea surrounding the island is rich in oil and natural gas (Cardoso, 2020; Justino et. al., 2011). The government finances $95 \%$ of its budget using money from a Petroleum Fund (Lao Hamutuk, 2020). Its GDP is approximately \$3.4 billion USD (2019 est.) (IMF, 2019). The population is generally very poor: $42 \%$ of the population live below the poverty line and $11 \%$ of the working-age population is unemployed (Inder \& Cornwell, 2017; GMN, 2020c), and 80\% of the population rely on agriculture for their livelihood. Other major economic sectors include services and industry (General Statistics Directorate, 2015; GMN, 2020c; Hill, 2017) and Timor-Leste's main exports include coffee, sandalwood and marble (Batterbury et. al., 2015).

\section{JOB SECTORS IN TIMOR-LESTE}

As previously stated, Timor-Leste has a public and a private sector. The public sector employs a substantial portion of the population in positions such as office clerks, schoolteachers, and construction workers (Hill, 2017). There are three main components of the private sector: the subsistence economy, where people grow food for themselves or their neighbours without necessarily involving the exchange of cash; the formal tax paying economy of local and foreign businesses; and the informal sector. The latter includes those who provide needs not covered by the other two sectors, generally are not registered and or tax paying, rarely have savings and generally live on the cash they earn (Hill, 2017, p. 4). The private sector encompasses positions such as security guards and company drivers, while the informal sector includes taxi, angguna ${ }^{27}$ and microlet $^{28}$ drivers, fruit sellers and small-scale vendors. Timorese nationals also find positions within local and international NGOs (Hill, 2017). As mentioned previously, the continuing rural to urban migration for schooling and waged employment does not change the reality that the number of formal jobs available in Timor-Leste, which is far too small to meet the needs of a growing youth population (Batterbury et al, 2015, GMN, 2020c).

\footnotetext{
${ }^{27}$ Small trucks with an open-air cargo section that charge a small fee to transport passengers between regional towns and villages.

${ }^{28}$ Mini buses providing public transport that operate within Dili and between regional centres.
} 


\section{THE SUNRISE OIL FIELD}

The government has championed its planned oil refinery project as a creator of job opportunities, but several civil society organisations regard this as highly unlikely, ${ }^{29}$ and call for the government to diversify away from oil and gas and invest more sectors with untapped potential such as agriculture and tourism (GMN 2020c; Oxfam Lao Hamutuk, 2020; Oxfam, 2020). The ongoing withdrawal of money from the oil fund at unsustainable levels by the government has created concern for the future wellbeing of the country (Lao Hamutuk, 2020).

\section{THE YOUTH BULGE}

Timor-Leste's large youth population has a big impact on both the economy and the education system, and could be either a blessing or a curse for the small island nation. A spike in births started in the 1990s and continued after the events of 1999, which has been termed the 'youth dividend' (Hill, 2017, p.1), and 39\% of the population are currently under the age of fifteen (Inder \& Cornwell, 2017). With limited job opportunities in the country and a high rate of unemployment, the youth bulge could either be a blessing or a time bomb. A large youth population means a large proportion of Timorese citizens being of working age, and able to engage in work that contributes to economic growth. On the other hand, if high levels of unemployment continue, causing a large number of young adults (juventude, or joven) to become increasingly bored and frustrated, with no job prospects, this could be a pre-condition for civil unrest in the medium-term future (Interview with businessman, 25/7/2019, Gleno).

According to Daniel do Carmo, the Director of FONGTIL ${ }^{30}$, 'it's not that juventude don't want to work, it's that work opportunities are very limited' (GMN, 2020c). Of the $11 \%$ unemployment rate, do Carmo identifies two types of unemployment. First, there are 'professionals', especially those who are graduating from universities and technical-

\footnotetext{
${ }^{29}$ Specifically, critics argue that Timorese nationals do not have the specialised training required for working on an oil refinery, meaning that overseas workers will likely be employed in these positions, and the oil itself will run out at some point anyway: Lao Hamutuk (2020).

${ }^{30}$ The organisation for local, national and international NGOs in Timor-Leste (Tetun: Forum Organizasaun Naun Governmentál Timor-Leste).
} 
vocational institutions, whose numbers increase yearly. Second, there are 'nonprofessionals', chiefly the large number of young people who have finished secondary school, presecondary school, or have not attended school, and who have difficulty finding work because they have no professional work experience as yet. Do Carmo believes that the large number of job seekers is due to little investment in agriculture, tourism and industrial sectors over the past ten years, and argues that the public, private and co-operative sectors must create opportunities for both skilled and unskilled people looking for work. A contributing factor is that many people do not view agriculture as proper work, unlike positions in the government, military, and NGOs. This thinking must change in order for opportunities in agriculture to be identified and for innovation to take place.

\section{OVERSEAS WORK AND REMITTANCES}

Overseas work is one way in which Timorese nationals can earn an income which they can use in a variety of ways, such as buying assets like houses and cars, investing in education or a business, and supporting their families (Interview with teacher, 25/8/2019, Ponilala). There are many countries in which Timorese citizens can find work provided they can obtain a visa and have the financial means to travel and live abroad. The most common destinations are Australia and South Korea, ${ }^{31}$ as well as Ireland, England, Japan, Indonesia, Portugal, the United States and New Zealand (Soares, 2015; Peake, 2013).

Seasonal work in Australia is the first choice for many Timorese nationals in search of work, as it is nearby, reducing the necessity of a long absence from home (Rose, 2019). The Australian Seasonal Worker Program (SWP) typically employs 1,000-2,000 Timorese workers at a given time (ABC, 2019; GMN, 2020k). As with migrants from Pacific countries, workingage Timorese citizens are hired every year for six-month periods to work on farms, orchards and vineyards during periods of high seasonal demand for labour (Overton et. al., 2020). Workers earn far more money at minimum-wage in Australia than they do from working in agriculture in Timor-Leste, allowing them to save a significant amount of money during their

\footnotetext{
${ }^{31}$ According to GMN (2020l), in June 2020 there were over 2,000 Timorese nationals working in South Korea and over 1,000 working in Australia.
} 
placement. The RSE (Recognised Seasonal Employer) scheme, run by the New Zealand Government, offers similar opportunities to the SWP.

There is also a well-trodden migration path from Dili through Portugal to Ireland. Many Timorese nationals have gone to industrial towns in Ireland to work in low-wage jobs, such as in chicken factories (Peake, 2013).

Consequently, remittances are a source of support for families of overseas workers, and a significant part of the Timorese economy. Remittance money that overseas workers send back to their families is spent on a variety of goods, from essentials like food and clothes to university tuition and investment into starting a new business (Soares, 2015, p. 12). This positive impact encourages more Timorese adults to migrate overseas to find work.

\section{AGRICULTURE}

Timor-Leste is divided into distinct agricultural zones, and different crops and animals are farmed according to geographical elevation and climate patterns. The type of crops farmed across the country vary widely, as do the types of animals raised by families. The distinct livelihood zones across the country include rice-growing regions on the north coast and coffee-growing in the central mountains (Williams, 2018). People tend to have small land holdings rather than large farms. Batterbury et. al. (2015) identify four farming systems: rain-dependent dryland farming; irrigated rice production; plantation of cash clubs; hunting and foraging.

Agriculture is Timor-Leste's largest economic sector (Williams, 2018). Even though farming is not necessarily seen as proper work, around $75 \%$ of the population are engaged in subsistence and semi-subsistence farming in rural areas, and agriculture forms the backbone of the economy (Batterbury et. al., 2015; GMN, 2020c; Hill, 2017). Over 64\% of working adults are engaged in agriculture as their primary work (Inder \& Cornwell, 2017, p. 17). As in many Pacific countries, subsistence farming acts as a kind of safety net, keeping families from starvation. People can put food on the table and earn a small amount of money from selling their produce. It is also a last resort for people who cannot find other work (Hill, 2017). The agricultural sector is generally characterised by low technology, low productivity 
and high labour intensity. However, while 'indigenous agriculture' is often undertaken without mechanization and with few inputs, farmers do have a high degree of self-sufficency (Batterbury et al, 2015, p. 621).

\section{COFFEE}

In the twentieth century, the Portuguese administration was on the brink of bankruptcy, and the government in Lisbon refused to send more money to the colonial administration. The Portuguese officials in Dili needed money fast, so they distributed coffee to the liurai as a way of financing themselves. The liurai made residents of their regions grow and harvest coffee, keeping a portion of the profit, and giving the rest to the Portuguese administration in Dili (Peake, 2013).

Today, coffee is the major cash crop of the country, and one of its largest exports, as the second-largest source of income after oil and gas (Howson, 2015; PR, 2016; Williams, 2018). Coffee is typically harvested between May and August in Ermera subdistrict (Interview with a parent, 1/9/2019, Ponilala). Across Timor-Leste approximately $19 \%$ of households grow coffee to sell, and another $18 \%$ grow coffee mainly for personal use (Inder \& Qu, 2018, p. 3). However, coffee has not miraculously become equitable in the post-independence period, with the inequality of coffee farming under the Portuguese administration now echoed in present-day production chains. Timorese farmers commonly learn very little money for their coffee, which is sold for a high profit by international - and even 'fair trade' - companies. According to Howson (2015), coffee production can trap farmers in an unprofitable, unequal cycle in which they are at the mercy of fluctuating market prices. Companies can push the price per kilogram down, which squeezes farmers for their coffee, in order to generate profits higher up the commodity chain. While other cash crops ${ }^{32}$ may offer higher profits, coffee remains firmly rooted in the economy, particularly in Ermera and Aileu districts.

\footnotetext{
${ }^{32}$ For instance, there has been a sporadic venture to grow vanilla near Railaco, the district capital of Liquica which lies about 45 minutes from Ermera vila (GMN, 2020i).
} 


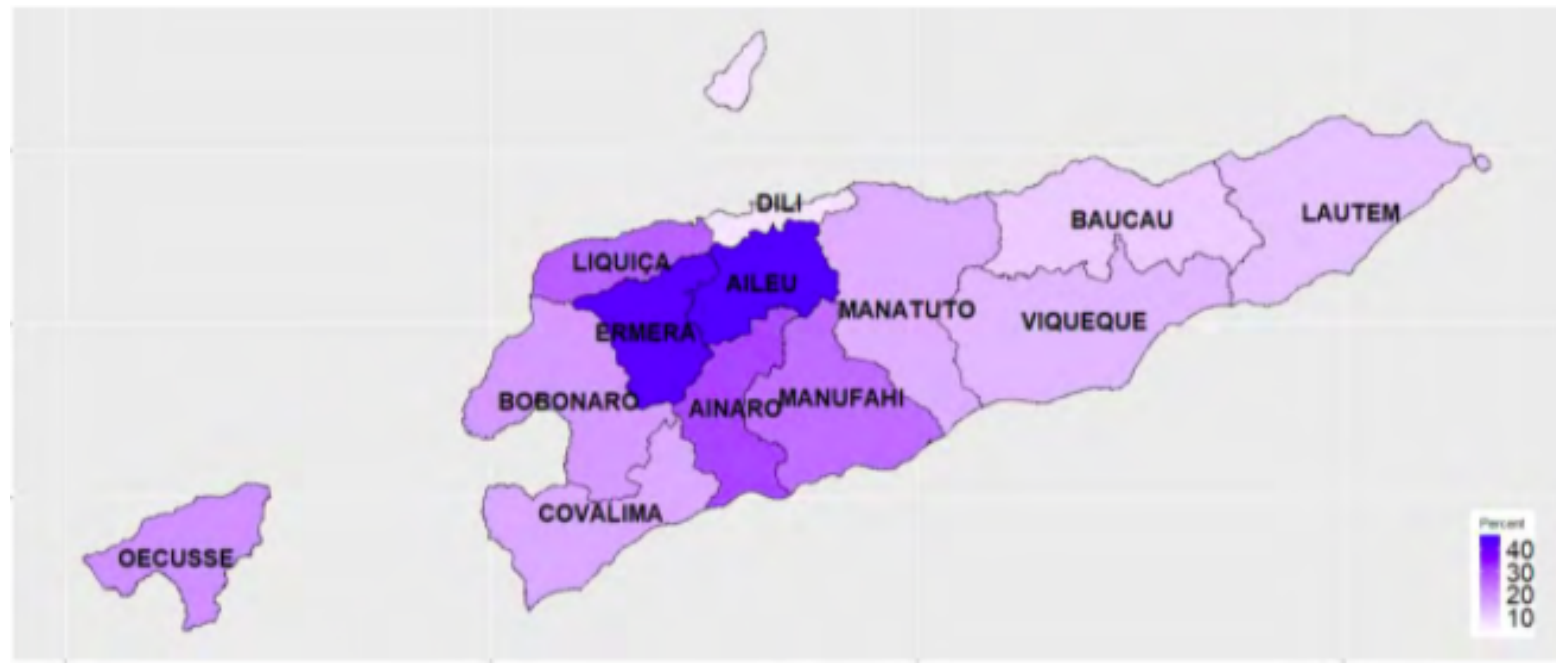

Map: the proportion of households in each district that grow and sell coffee (according to 2015 national census data). Source: Inder and Qu, 2018, p. 5.

\section{ENVIRONMENT}

Farming and logging activities have damaged the land, which has been stripped of its valuable sandalwood trees since the 1300s (Fox, 2003). The poor state of the land may partly be a result of the Indonesian occupation, as the Indonesian army stripped the land of trees. One academic, who visited Dili in 1974 and returned after the country had gained independence, found a changed land: where previously there had been lush jungle, the hills around Dili were now dry and visibly barer, and only a couple of pockets of jungle remain (Interview, 19/9/2019, Dili). Land clearing and slash-and-burn farming have led to loss of ground cover and destruction of the topsoil, reducing the productivity of crop plantations (Hill, n.d.).

Another significant environmental problem, and one which is faced across the world, is the accumulation of waste, particularly single-use plastic. There is a recycling system in place for aluminium cans, but not for other kinds of waste. The government is taking small steps to address this issue, recently implementing a zero-plastic policy, and partnering with an international NGO to create a recycling system (Da Silva, 2017; GMN, 2020b). 


\section{CLIMATE CHANGE}

Climate change is likely to pose further challenges in the near future. It is likely to affect the whole of Timor, and especially small-scale farmers, who will be the most vulnerable to changing climate and more volatile weather patterns. Likely changes include higher temperatures, more drought, more unpredictable weather patterns, more severe natural disasters, and rising sea levels. A xefi suku (village chief) has raised concerns about climate change lowering agricultural returns, including in coffee farming, in Liquiça municipality (GMN, 2020k). Adapting and increasing resilience to climate change is vital for the small country, which produces negligible $\mathrm{CO} 2$ emissions.

The state government and international NGOs appear willing to invest in building resilience to climate change and natural disasters (GMN, 2020a; GMN, 2020f; GMN, 2020h). Treeplanting activities of a local NGO in Dili gained news coverage in late 2019, and got school children involved in the seedling planting, and in February 2020 the President and Prime Minister of Timor-Leste participated in a mangrove tree planting event. The President gave an address at this event on the importance of rehabilitating the coastline and building resilience to climate change and natural disasters. (GMN, 2020h). If this enthusiasm from both government and local organisations were supported financially by international donors and large NGOs, the country could well gain vital resilience to future decades of weather and climate change.

\section{CONCLUSION}

The complexity of Timor-Leste's colonial history and cultural landscape and its rapid transformation into an independent nation in the twenty-first century has created an uncertain environment for its citizens, where a struggling education system feeds into an economy and environment that is facing major challenges. There has been much change in the past twenty years, and the nation has made great strides forward from the chaos and destruction of 1999. It is within this context of both collective achievement and major obstacles that a large teenage population is growing up and making choices about their future. The following chapters will confirm that education is valued highly by students, families and their communities, and viewed as a means to gain financial security in this 
uncertain environment. Attending university or other educational courses appears to be central to most teenage students' vision of a good life, and their parents may work very hard to support them in continuing their education. 


\section{Chapter 5: Community and Family Life in Ermera Subdistrict}

\section{INTRODUCTION}

Houses spread outwards from the centre of Ermera vila. They are built up hills and down gullies. Every household is part of an administrative structure which ascends from aldeia (hamlet), through suku (village) and a postu administrativu (subdistrict) to munisipiu (district). There are five subdistricts within Ermera municipality: Railaco, Ermera, Hatulia, Letefoho and Atsabe.

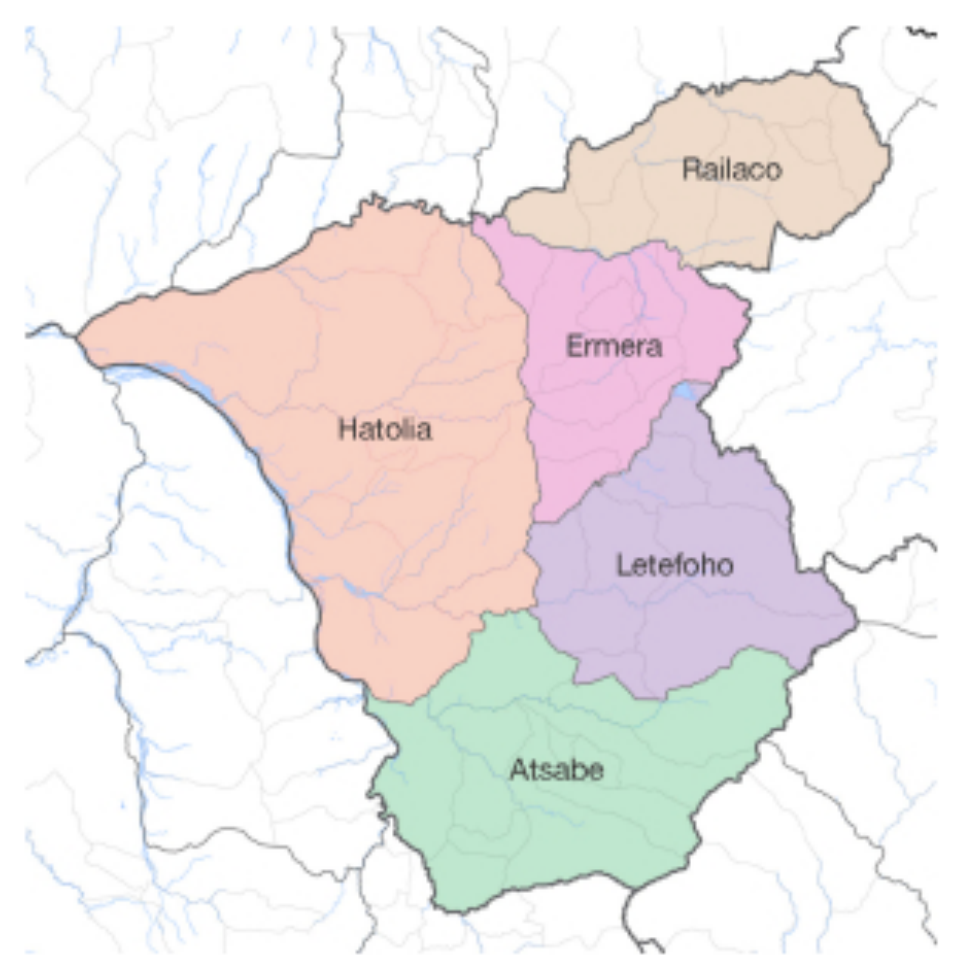

Map of Ermera municipality showing the five subdistricts. Source: RDTL, 2015.

Ermera vila is the capital town of Ermera subdistrict. Gleno, Ermera vila and Ponilala form a rough triangle within Ermera subdistrict. Mirtutu, where I also spent a little time, lies on the hills above Ermera vila. From early in the morning, men and women work in their farms and gardens in the growing warmth from the sun, which rises over the mountains and the tall moluccan albezia trees. The weather in the dry season is cool and clear. 


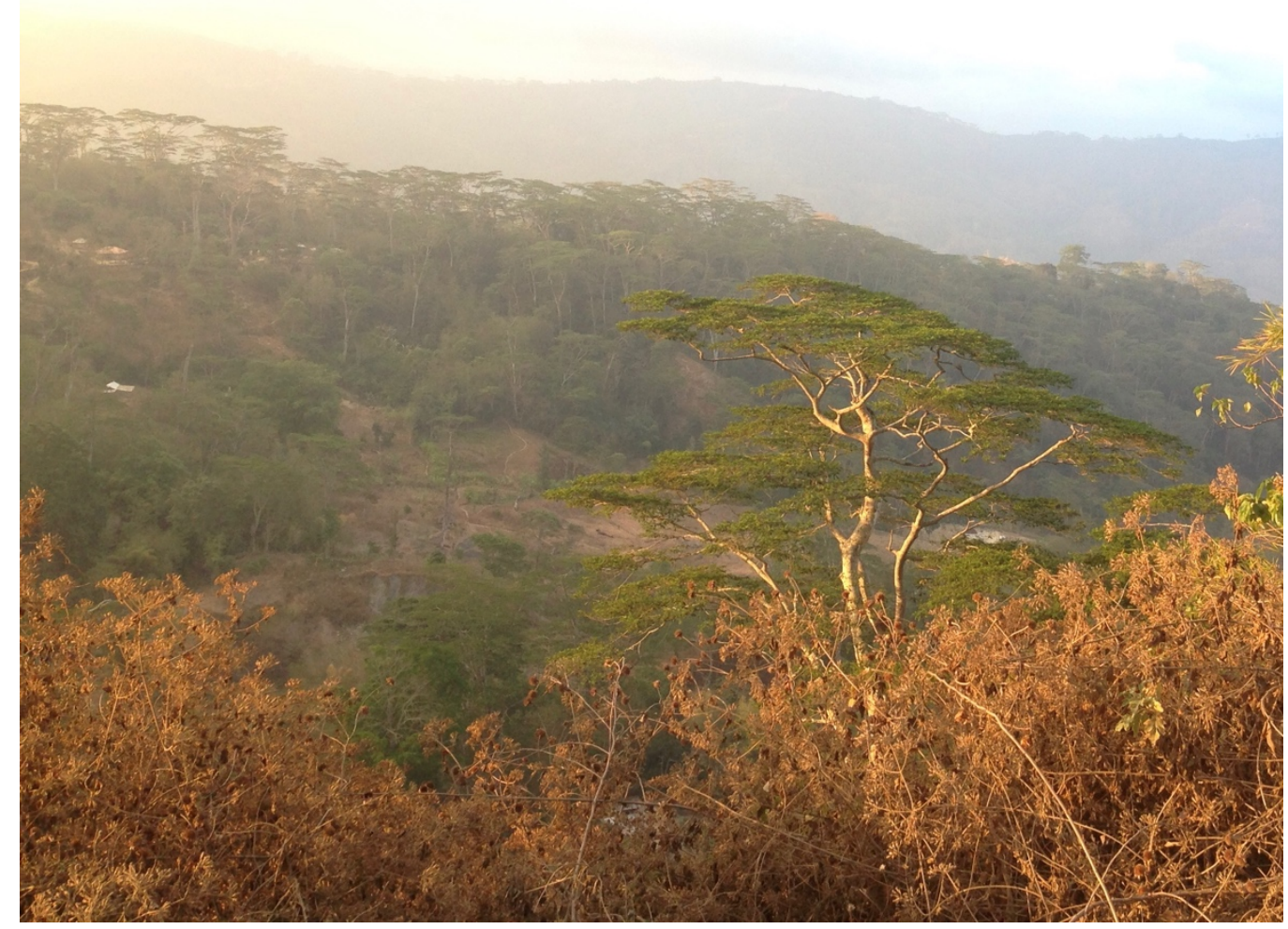

View from the road between Ermera vila and Ponilala looking north toward Dili. Source: Own image.

During the day, small children play along the gravel road leading into the vila. In the early morning, high school students walk into town in pairs, threes or larger groups. They pass a couple of motor repair shops and small kiosks (kios) selling goods like oil, snacks, water, superme $e^{33}$ and coffee in tall plastic thermos flasks. Primary school students in yellow and blue uniforms mill about around the concrete buildings of the public primary school below the main road. Shops which are a little larger than the kiosks sit next to each other along the street. Each sells a fairly similar range of goods: $p u l s a^{34}{ }^{,}$eggs, cooking products, and sweets.

${ }^{33}$ Cheap packaged noodles imported from Indonesia.

${ }^{34}$ Vouchers for mobile phone credit, and prepaid electricity for houses. 
Women sit behind small tables along the market street, selling vegetables, fruit, bread, tofu and tempeh. Further along the street, towards the police station and the path toward the 20 de Agosto School ${ }^{35}$ and Mau-Kruma School, a couple of vendors sell satay (skewers of meat) cooked on portable grills. Every Friday Ermera vila has a market day, and from early morning the main street is filled with vendors who come to the town to sell a larger range of goods: produce, pots, pans, betel nut, knives, rice cookers, ten-kilo sacks of rice, and second-hand clothes.

One student from Ponilala told me that his father works on their farm the entire day, starting at 6am and finishing at 6 or $7 \mathrm{pm}$. The two families I stayed with would also get up at dawn. The women and girls would prepare breakfast and family members would start working on the family farm. Women might spend the day doing household work, looking after children, staffing their kiosk, selling produce in the market, and perhaps juggling waged work such as teaching.

Many residents in Ermera vila and Ponilala, particularly women and girls, attend the Catholic church at the top of the market street on Sunday morning, and there is an early mass held every morning in Ermera vila. The parish priest, $\mathrm{Amo}^{36}$ Deonildo, also works as the Director of Imacon School and teaches Religion classes, which makes for a busy schedule.

Priests appear to be the most respected members of their parish communities. Xefi suku and xefi aldeia (village and sub-village chiefs) also hold high positions. I once heard a xefe suku referred to as liurai, 'king', at a party, suggesting that they fill a role not unlike the feudal kings of pre-colonial and colonial times. School directors and teachers, despite the low salaries of the latter, are respected community members, along with policemen. Older people are also respected, including older women. This is readily apparent at festas (parties): older men and women are offered food and drink before others. Ermera is a patriarchal society, and men hold the key positions of authority (Interview with a school

\footnotetext{
35 'Escola Pre-secundária 20 de Agosto Ermera': the public pre-secondary school in Ermera vila.

${ }^{36}$ Honorific term for a priest; used interchangeably with 'Padre'.
} 
director, 4/9/2019, Ermera vila). I did not meet any women who held positions of status other than teachers. ${ }^{37}$

\section{REFRAMING CULTURAL OBLIGATIONS}

In Ermera, coffee is generally harvested between May and August. From June to September a lot of talk revolved around coffee, and I saw great tarpaulins spread out in the marketplace and behind family homes where coffee beans were spread out to dry. Families pick the coffee on their plantations, dry it, husk it and mill it, ready to be sold for $\$ 1^{38}$ to $\$ 1.50$ per kilo for Arabica coffee, and a little less for Robusta coffee (Conversation with resident, Ermera vila). This means that families receive a substantial portion of their yearly earnings around September. Consequently, the majority of cultural events (lia) such as wedding parties, traditional observances at sacred houses, baptisms, dowry meetings and various types of funeral ceremonies ${ }^{39}$ are held in the September-October period, as families will have the money to spend on buying animals such as cows, pigs and chickens, and giving cash gifts at these events.

Amo Deonildo viewed lia as both a good thing and a bad thing. On the one hand, it is part of peoples' cultural identity, on the other, it can lead to unwise use of money [7] (Interview, 4/9/2019, Ermera vila). According to conversations with several other residents in and outside Ermera vila, the pressure to meet obligations for lia mate lia moris ${ }^{40}$ can cause problems. It can involve a kind of 'keeping up with the Joneses' mentality, where not contributing enough to a party or event can mean a loss of face. Family members may strive to bring more to an event than members of other families in an effort to outdo them. Not participating in lia may result in social ostracisation, and some believe that a person will be

\footnotetext{
${ }^{37}$ The capital city is a bit different: there are women in high positions within Parliament, and female directors of NGOs such as FOKUPERS, a womens activist organisation.

${ }^{38}$ All figures refer to US dollars.

${ }^{39}$ Cultural events include festas, halo uma lulik (observances at sacred houses), dansa (dances), kore metan (one-year funeral party, in which the black clothes worn by family members are symbolically burned), halo rate (observances at the graves of deceased family members), and festa kasamentu (wedding parties): interview with school director, 3/9/2019, Ermera vila; informal conversation with student).

${ }^{40}$ 'Life and death rites': cultural ceremonies for events surrounding life and death.
} 
cursed with ill-health for not taking part (Informal conversation with friend, 9/6/2019, Dili). Dr Ramos Horta views cultural obligations as a challenge for teenagers and young adults due to the negative flow-on effects which can stem from them. A family might arrange a big funeral and kill six buffalo, eating a lot of meat over a few days, and then none for the rest of the year (interview, 6/8/2019, Dili). Animals are expensive, with a cow costing anything from $\$ 600$ to $\$ 1,000^{41}$, and families might spend all their savings or borrow money in order to meet obligations for an event rather than spending it on food, other household necessities, or children's education (Interview with businessman, 25/7/2019; Gleno).

Berta Antonieta Tilman Pereira, a researcher at Lao Hamutuk, has a different view of cultural obligations. In the past, the regular exchange of animals as part of observing deaths and marriages kept goods circulating between families, encouraging wealth to be evenly distributed within communities. The obligation to bring goods to a cultural event could have the effect of promoting equality and overall social wellbeing. However, as Timor-Leste has transformed into a capitalist economy and economic transactions have become largely monetized, the price of animals has ballooned, leading to the negative outcomes described above. From this perspective, it is capitalism rather than cultural activities which is the detrimental force (interview, 8/8/2019, Dili).

Several Ermera residents mentioned a priest called Amo Lorenzo during our conversations aobut lia. This former priest of the diocese of Gleno saw the financial strain that spending a lot of money on lia put on families, and was dismayed at the way their quality of life suffered as a result. He wanted families to invest in their children's education instead of spending money 'arbitrarily' on lia. His efforts towards finding a solution led to a community meeting in around 2011 or 2012 where it was agreed that no more than a certain sum could be spent on lia, which now depends on an individual's means. Some sanctions can be applied to those who contravene this law. ${ }^{42}$ The purpose of the law is to encourage residents of Ermera subdistrict to focus on their children's ability to obtain a 'good life' in

\footnotetext{
${ }^{41} \mathrm{~A}$ breed of black cow (karau metan) is considered particularly special, and is presumably still more expensive. Conversation with foreign volunteer, July 2019, Mirtutu.

${ }^{42}$ For instance, not being allowed by the Church to process documents such as baptism certificates.
} 
the future (Interview with Amo Deonildo, 4/9/2019, Ermera vila; conversation with teacher, Ermera vila).

\section{COMMUNITY EFFORTS TO BUILD SCHOOLS IN ERMERA SUBDISTRICT}

Gleno is not the only place where there has been a push from within the community to expand children's access to education. Mau-Kruma School is a fairly new addition to Ermera vila. It was built in 2014 through community initiative rather than by the government. At the time, five or six teachers at Imacon School, which was founded in the 1990s, saw the need for a public senior secondary school to meet the demand of a growing youth population. It would give families a cheaper alternative to the relatively expensive Imacon school, and a closer alternative to the senior secondary schools in Gleno (conversation with teachers, 17/9/2019, Ermera vila).

The group of educators gained permission from the surrounding community to use an area near the 20 de Agosto School, and applied to the government for funding. The MoE told the group to show their commitment to the school: if in a year or two they had it set up and running, the Ministry would start financing it and pay teachers' salaries. The teachers worked 'voluntarily', charging students around $\$ 0.50$ or $\$ 1$ a month for tuition, and using this money to pay themselves a small salary. Enrolments continued to increase, and after a year or two the group reapplied for registration. This was granted, and the government then began paying teachers' salaries, providing standard textbooks, and generally assuming the governance of Mau-Kruma School. Friends of Ermera, an Australian group based in the city of Casey in Victoria, has helped to finance buildings and electricity. ${ }^{43}$ Australian schools have also provided financial support to both Imacon and Mau-Kruma Schools as friendship schools, as has a parish group from Western Sydney. ${ }^{44}$

\footnotetext{
${ }^{43}$ At several points, while I was visiting Mau-Kruma school, teachers would point down the hill towards two classrooms, or up towards the lights in the classrooms and the teachers' staffroom, saying that it had been financed by the Friends of Ermera group.

${ }^{44}$ In late June to early July, the winter break period for Australian schools, three groups visited Ermera vila. The first two, both from Victoria, stayed in a guesthouse across the road from the public primary school. The second was a delegation of adults and students from two parishes in Western Sydney which stayed at the Residensia (the priest's quarters) at Imacon school. The groups would visit their friendship school, bringing sports balls and other gifts. The school would welcome them,
} 
Similar efforts in Ponilala have also resulted in a school being built in that community. In the early 2000s the parish priest and two teachers organised a community meeting for residents to identify the main challenges they were facing. These were health, electricity, clean water, roads, and education.

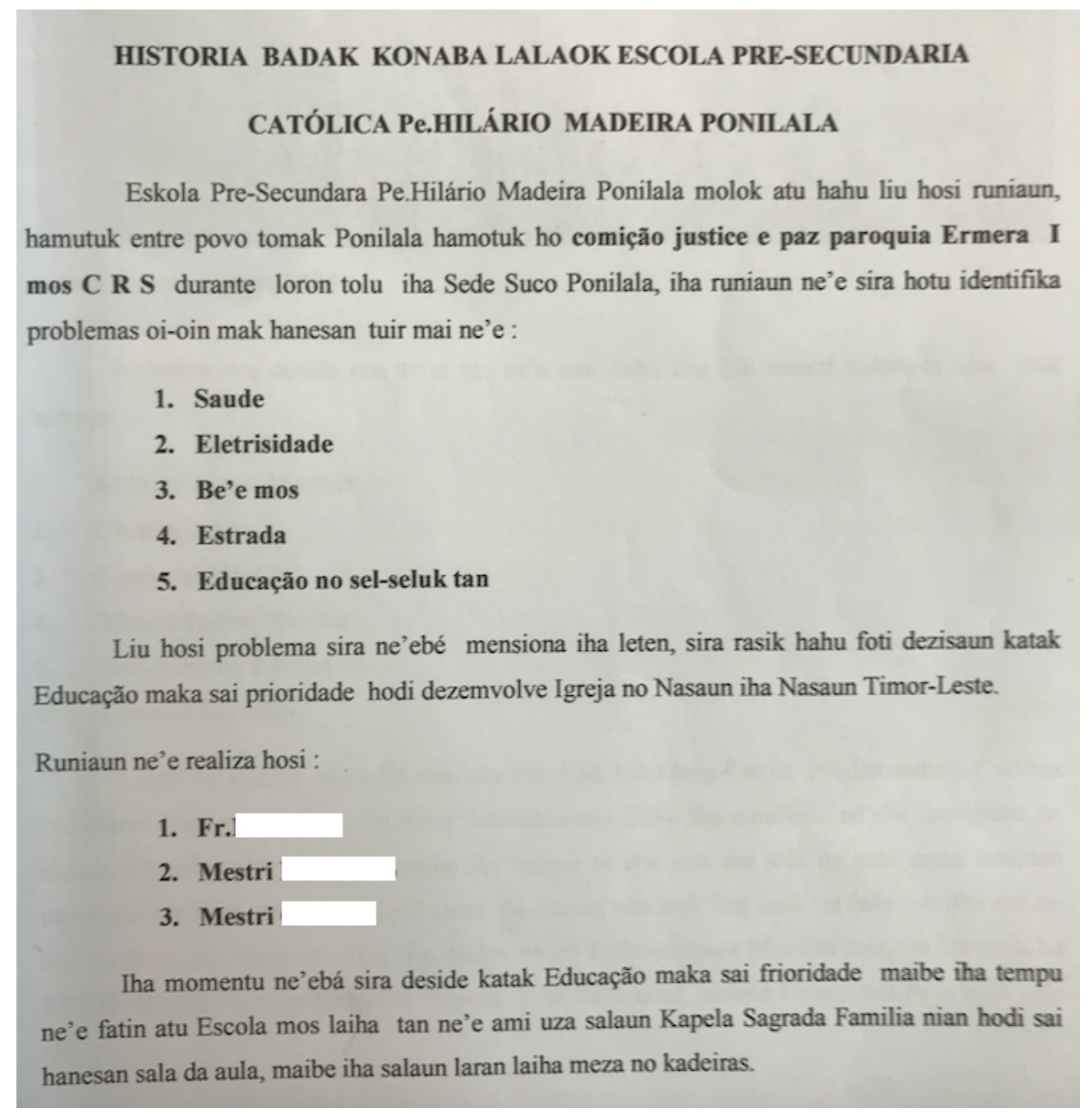

Image: first page from an information booklet on the founding of the Catholic pre-secondary school of Ponilala. Source: Martins, 2008, p. 2.

It was decided that education was the foremost issue. With no secondary schools in Ponilala, local students had to travel a long distance to attend school elsewhere. At the time, there was no obvious area in which to build a new school, so the chapel room of the visits and music and dance performances by its students. 
local church was used. ${ }^{45}$ The community built one breezeblock classroom in 2005 . As student numbers grew, teaching hours were split into morning and afternoon sessions; the primary school classroom was requisitioned for the latter in 2006. In the same year, a group from the Australian Friends of Ermera arrived to find a friendship school for St Paul's Anglican Grammar School and Kindergarten in Gippsland, Victoria. Mr Felix, an English teacher at the time, described their arrival at exactly the right moment, offering financial help to the community for educational development. Mr Felix spent a month talking and fundraising at different schools around the Australian state of Victoria and raised just over $\$ 9,000$. The Friends of Ermera chipped in, and with $\$ 13,500$ construction of Ponilala's first pre-secondary school began. Over the past fifteen years the school has grown from a chapel room with no chairs or tables to a school with over one hundred students, several furnished classrooms and a small staffroom (Interview, 25/8/2019, Ponilala; personal correspondence with teacher, 30/3/2020).

After finishing Grade 9, many continuing students from Ponilala walk five kilometres to attend secondary school in Ermera vila. However, students living downhill along the border with Liquiça must travel at least two hours to do this, which is a substantial barrier to attending school. Two English teachers told me of their wish for a future senior secondary school to be established to meet the needs of these students, and in September 2019 there were plans in motion to build a branch of NCES in Ponilala. ${ }^{46}$

It is possible that the teachers' and priests' social standing has swayed the Ponilala community toward viewing education as a priority, and that community members passively supported the view of past meeting organisers. Either way it is clear that priests and teachers of Ermera subdistrict, through hard work and dedication, have succeeded in achieving the significant development which they have envisaged for their society.

\footnotetext{
${ }^{45}$ Information booklet on the history and financing of Padre Hilario Madeira Catholic Pre-secondary school, Martins, 2008.

${ }^{46}$ It is worth noting that during my fieldwork I was subtly asked to contribute financially to building the envisaged school if I found myself in a 'good position' in the future. As a malae, and also perhaps as an Australian, like the Friends of Ermera group, I was seen as a potential patron of the school.
} 
Residents in Mirtutu have also recently built a school for their community. From 2017 to 2018, men and teenage boys built a kindergarten using timber cut from nearby trees, bamboo, corrugated iron and other locally sourced materials. Women would cook large meals daily for the builders, so construction was a community effort. Volunteer teachers and local influential leaders campaigned for registration, which the MoE agreed to grant provided the community proved their commitment by running the school successfully for a couple of years, as it did with Mau-Kruma School. This is a third example of a school being set up through community initiative rather than by the state government. ${ }^{47}$

\section{FAMILY AND COMMUNITY AS BOTH SUPPORT AND PRESSURE}

In Ermera subdistrict, families are large. The parent participants who I interviewed generally had between four and twelve children. Parents may also take care of children who are not their own: one participant had ten biological children and five adopted children (see Case Study on p.110), and another had no children of her own but was effectively parenting her younger sister and this sister's son.

For teenagers, families can be both a source both of support and a pressure. First, raising the money to send children to school can involve a lot of sacrifice for all the family. One teenage interview participant described the way in which his father worked extremely on his farm to earn enough money for his children's tuition. He recalled sometimes returning home from school and not having anything to eat, and understanding that it was because his father was doing everything he could to put his children through school. His father once bought a motor for his son to be able to use in the future, but then had to sell it to pay for his elder sister's university tuition. This student clearly loved his father a lot and said that he wanted to find a good job in the future in order to be able to repay his father's kindness and support. For their part, teenagers do a wide range of chores to help their parents at home (for detail on students' work at home, see Appendix 6).

\footnotetext{
${ }^{47}$ Correspondence with a foreign volunteer who lived in Mirtutu between 2017 and 2019, and helped with construction.
} 
In Ermera, sharing appears to be more of a norm than it is in Australia or New Zealand, both within families, between neighbours and in communities more generally (interview with foreign volunteer, 13/9/2019, Mirtutu; personal observation). This means that income from a formal job may be spread among many family members, as with remittances from overseas. In short, strong family and community ties means that a family's capital is often shared among many people (Interview with school director, 4/9/2019, Ermera vila). A friend and teacher told me that, when he was building his house, some neighbours came to help him; sometime later he gave some of the family's corn harvest to these neighbours, and that this kind of exchange was not unusual. In April 2020, a student I had met while in Timor-Leste during my fieldwork told me a similar story on Facebook, and sent me photos of the brick foundations he had helped to lay for a neighbour's house. This sounds like the voluntary gifting of labour (bayanihan) or the reciprocal labour exchange (hungus) described by Gibson-Graham (2005) in the Philippines.

Given the difficulties paying school fees, tensions can arise if children make extra demands on family resources. Children might ask their parents for money for non-necessities. One teenager I talked to, while not explicitly saying this, clearly thought that her sister not doing any work (halimar) and asking her father for money for clothes and snacks was poor behavour. Similarly, a policeman talked of a distressing trend he observed in another subdistrict capital town in Ermera, where parents lived a life of drudgery as farmers, and some young adult children demanded money to buy unnecessary goods, drink and gamble. He observed that more children did not attend school than in Ponilala, and consequently a large number of young adults without jobs wandered around and led bored, dissipated lives, living off their parents' hard work for little money on the land.

Strong family ties may also compound the pressure arising from cultural obligations. If one person is asked by their family to buy an animal for an event such as a kore metan, many spend all their savings or borrow money to meet the request (Interview with businessman, 25/7/2019, Gleno). 


\section{HEALTH}

East Timor has been squabbled over by Dutch and Portuguese forces for over 400 years, suffered under Portuguese colonial rule, and fought against one of the most brutal regimes in human history. With this history, it is little surprise that many ema kiik are extremely poor, and serious illnesses such as dengue fever, malaria, tuberculosis, leprosy and HIV/AIDS are ongoing threats, especially to those living outside Dili (Inder et. al., 2013).

Dr Ramos Horta believes that the greatest challenges for teenagers and young adults in terms of general wellbeing are poverty, malnutrition, tuberculosis and HIV/AIDS (interview, 6/8/2019, Dili). One Dili clinic registered a record number of tuberculosis cases in February 2020, and HIV infections were also increasing (GMN, 2020e). According to Provo et. al., (2017), 40\% of women aged 14 to 60 across the country were anaemic. Mental illness, in a country with a fairly recent civil war, and the scars of both the Indonesian occupation and the more distant Portuguese colonial control, is also a major challenge to citizens' wellbeing (Palmer et. al., 2017). These myriad health issues impact on the development of education in the country.

One teacher and NGO staff member spoke of the need for sexual health education for teenagers, and described the consequences of its current absence in schools (interview, $30 / 3 / 2020$, Wellington). She observed that a lot of teenage girls get pregnant and drop out of school. The Catholic Church and the government oppose sexual education in schools, because they believe it might encourage teenagers to have premarital sex. However, boys' and mens' consumption of pornography is a kind of sex education in itself, and educators have highlighted its connection with teenage pregnancy (more detail can be found in Appendix 6). The authoritarian teaching culture inherited from Portuguese and Indonesian times, coupled with the fact that many students move to stay with relatives to go to school means that teenage girls may have very little support. Furthermore, those who fall pregnant may be too afraid to tell their family. Girls are the focus of social and familial control, while boys have a great degree of personal freedom. Girls are also the focal point for government policies and laws, which are often punitive. The pressures on girls, who may be as young as fifteen, can lead to their abandoning or killing the baby, or even themselves. This teacher 
has run sex education and reproductive health programs on a number of occasions since 2015. She believes that it is vital for girls to learn about their bodies and about consent. She hoped to develop seminars for boys in the future, as she saw it as equally important for them to learn about respectful relationships and women's reproductive cycles.

\section{NUTRITION AND MALNUTRITION}

Malnutrition is a key concern for children across Timor-Leste (GMN, 2020e; World Bank, 2013). It affects the autoimmune system and leaves the body susceptible to a range of illnesses. According to Provo et. al., (2017, p. 15), in 2013, half of Timorese children under five were stunted. High rates of undernutrition among women are a contributing cause. Food insecurity is a great challenge for households, and many families endure a hungry season prior to rice, maize and coffee harvests (Howson, 2015). Hunger impedes learning: many children already walk a long way to school, and if they arrive tired and hungry they have a limited attention span and experience difficulty concentrating in class (interview with Mr Felix, 25/8/2019, Ponilala). To combat malnutrition the government and the UN World Food Programme jointly launched a scheme providing free lunches to primary students across the country (conversation with teacher, 22/7/2019, Mirtutu). In 2013, in consultation with PERMATIL, the government started a school garden programme, envisaging students and teachers growing crops to contribute to the school food program (Lemos, 2016), as mentoned in Chapter Four. Director-General Antoninho Pires confirmed that the project is currently underway, and if it is successful there are plans to extend it to secondary level (Interview, 19/9/2019, Dili).

Residents of Ermera subdistrict mainly eat rice and some vegetables, and very occasionally meat (Interview with businessman, 25/7/2019; Gleno; personal observations). Cultural obligations are a drain on money which could otherwise be spent on buying more - and more varied - food for a household, and farmers prefer to sell all their produce for money and spend the earnings on third-grade imported rice. One businessman observed that a lot of older women were taller than the majority, which suggests a deterioration in nutrition levels in the past fifty years. 
A possible reason for such a deterioration may be the introduction of white rice, which has come to dominate people's diet across the country. It is cheap and easy to prepare, and it seems to be embedded in daily life. When I commented in front of one priest in Ermera subdistrict that rice wasn't the most nutritious of foods, he looked at me as though I had said something blasphemous. White rice is generally imported cheaply from countries like Indonesia and Vietnam. It is grown in some parts of the country, but local yields aren't high quality enough to be sold on the global market (Kammen, 2012). According to Hill, many Timorese citizens, particularly those with an education, have been convinced by Indonesian settlers that their traditional diet of root crops and greens vegetables is 'uncivilized' and were persuaded to eat large amounts of white rice with little nutritional value compared to staple foods like cassava, maize, sweet potato and taro (Hill, 2007). The favouring of white rice over more nutritious root crops appears to now be commonplace in Ermera subdistrict.

However, most people living in Ermera subdistrict still grow food on their farms and in their gardens, including root vegetables. This guards against famine, as families have food in the garden to fall back on if money runs out completely. Vegetables and rice are more nutritious than junk food like sweets and soft drinks.

\section{CONCLUSION}

In all three locations I spent time in - Ermera vila, Ponilala and Mirtutu - there have been successful initiatives by teachers, priests and residents to develop education for their communities. Consequently, many students who might previously have been unable to access education can now attend a school nearby. There remain many challenges to student learning, including health challenges, and along with those specifically faced by teenage girls. Many parents work very hard to support their children, and have high hopes for their education. For their part, teenagers support their families by doing a significant range of chores at home (see Appendix 6).

For these three communities, a good life appears to include children being able to get an education close to home, families being able to live comfortably, being in good health and participating in cultural events. 


\section{Chapter 6: Economy and Development}

Agriculture is the carpet of life in Ermera municipality. While there are some formal jobs in Ermera vila, most families work in their farms and gardens. Students overwhelmingly want to go to university rather than work in farming, but with high unemployment and limited formal employment opportunities a tertiary degree cannot ensure future employment. At all levels of the economy there is reference to 'development' as a desired result of education, and to young adults as those who should be its driving force. It is important to examine whether state-level rhetoric matches what is valued and needed at a local level.

This chapter provides a description of the economic activity of the district and investigates the link between university and the job market. It then discusses the significance of agriculture and the environment to local livelihoods and examines the meaning of development in the context of education and livelihoods.

\section{DESCRIPTION OF THE ERMERA ECONOMY}

\section{JOBS IN ERMERA SUBDISTRICT}

It is possible to gain an impression of the diversity of work that people are engaged in from a small sample of the parents I interviewed in Ponilala. They were asked to identify which types of work they did to earn a living.

Table 6: The Work Interviewed Parents do to Earn Money

\begin{tabular}{|l|l|}
\hline Participant & Type of work \\
\hline 1 (M) & $\begin{array}{l}\text { Carpenter, xefi aldeia, farmer (corn, cassava, potato), harvests } \\
\text { coffee. } \\
\text { Wife: Housewife, farmer, helps harvest coffee. }\end{array}$ \\
\hline 2 (M) & $\begin{array}{l}\text { Carpenter, farmer, harvests coffee. } \\
\text { Wife: Housewife, same as above. }\end{array}$ \\
\hline $3(\mathrm{~F})$ & Farmer, harvests coffee, collects and sells wood. \\
\hline
\end{tabular}




\begin{tabular}{|l|l|}
\hline 4 (M) & $\begin{array}{l}\text { Farmer, harvests coffee } \\
\text { Wife: Housewife, helps with above. }\end{array}$ \\
\hline 5 (M) & $\begin{array}{l}\text { School coordinator, volunteer teacher in the community, harvests } \\
\text { coffee, animal husbandry (has one cow). } \\
\text { Wife: Housewife, harvests coffee. }\end{array}$ \\
\hline 6 (F) & $\begin{array}{l}\text { Housewife, farmer, animal husbandry, coffee, collects and sells } \\
\text { wood. } \\
\text { Husband: same as above. }\end{array}$ \\
\hline 7 (M) & $\begin{array}{l}\text { Farmer, harvests coffee, animal husbandry } \\
\text { Wife: Housewife, same as above. }\end{array}$ \\
\hline 8 (F) & $\begin{array}{l}\text { Now retired, volunteers at church as a catechist. Formerly ran a } \\
\text { kiosk, harvested coffee, animal husbandry. }\end{array}$ \\
\hline 9 (M) & $\begin{array}{l}\text { Policeman. } \\
\text { Wife: Housewife. }\end{array}$ \\
\hline
\end{tabular}

\section{Formal work in Ermera subdistrict}

Formal, waged jobs in Ermera vila included teachers, school principals, several doctors, nurses, police, and military personnel. I also met a clerk who worked at the office of the xefi suku. Of the 120 Grade 12 students surveyed, two students' fathers worked for private companies, two were security personnel, one was a driver and one was an agricultural extension worker. Two worked as public servants, one in electricity, and another as a ViceDirector of Water and Sanitation. Four of the students' mothers and two students' fathers worked as teachers.

Of the eleven students interviewed, one was the daughter of the policeman, one had a father who worked as a teacher, and also received the veterans' salary, and one had a mother who worked in Dili as an agricultural extension officer, and came back to visit during national holidays.

There were a greater number of formal jobs in Gleno, which is the largest hub of economic activity in Ermera district. In Gleno, formal positions include teachers, principals, police, clerks at the banks, phone shops and municipal government branches, staff members 
working for non-government organisations, hospital staff, staff at $\mathrm{ETCl}^{48}$, and staff working in warungs $^{49}$. Residents of Ermera vila might have work in Gleno in conjunction with Ermera vila. One teacher living near Ermera vila had three teaching positions. He taught at a school in Ermera vila (although he appeared to be away for weeks on end, and in fact, I only saw him once at this school over the course of my fieldwork); and at a school in Gleno, as well as at $\mathrm{ETCl}$. There is a sizable difference between the income from different formal positions. Teachers typically earn around $\$ 100-\$ 120$ per month, while doctors make around $\$ 600$ per month (conversation with teacher, Ermera vila).

\section{Informal work in Ermera sub-district}

Formal sector jobs are held by a minority: most people are self-employed. Most people by contrast are self-employed. Ten of the eleven interviewed students had at least one parent who undertook informal work for a living. 99 of the 120 students surveyed reported that one or both parents worked in agriculture, including selling produce and animal husbandry. Just eight specified that their parents grew coffee, although coffee-growing is so ubiquitous that I suspect many families grow both coffee and other produce (mostly vegetables, but also fruit, corn, and rice). Both parents of two students had died, and one of these orphans, a twenty-year-old, worked as a farmer and grew coffee to support himself.

Many students (including those interviewed) specified that their mother was a housewife, often alongside farming work. Housework is clearly considered women's work. ${ }^{50}$ Two students specified that their mothers were vendors.

One student reported that, along with farming and coffee, his father worked on miscellaneous projects. During my stay in Ermera construction work was being done on the road leading into Ermera vila. Farmers typically take up this temporary work, spending

\footnotetext{
${ }^{48}$ East Timor Coffee Institute.

${ }^{49}$ A simple Indonesian-style cafeteria.

${ }^{50}$ However, two teachers, who I stayed with during my fieldwork, explained that they worked in shifts. One taught in the morning while the other looked after their children, and they would swap over in the afternoon. If his wife was late returning from teaching, her husband would put the rice on to cook for lunch.
} 
Monday to Saturday under the sun (conversation with foreign volunteer, Mirtutu). They would work with bobcats and by hand to reinforce the side of the road in a terrace pattern using chicken wire fencing and large rocks.

Three of the students' parents ran a kiosk. There are kiosks dotted along the main road stretching from Gleno to Ponilala, owned and run by local families. Two of the students' families owned a shop, including a workshop, and the father of one student worked as a mechanic. There was a motor repair shop just outside the city centre, and I would see several men working there when I passed. Two of the students' mothers worked as seamstresses. They may have worked at a guesthouse near the two schools. Groups from two Australian schools would regularly stay for a few days at the guesthouse during the winter term break, and the seamstresses would earn good money by local economy standards by organising beds and catering for them.

Eight of the surveyed students' fathers worked as carpenters, and four of these carpenters were also farmers. One student's father was a xefi suku. I interviewed two fathers who worked as carpenters in Ponilala. One was the xefi aldeia, a carpenter and a farmer. According to the teacher who facilitated my interviews, carpenters made reasonably good money, and they appeared to live fairly comfortably. The Padre Hilario School of Ponilala was constructed by two carpenters from the area, along with six assistants, who would have all been paid for their work with the money raised by Mr Felix and the Friends of Ermera group.

One student's mother worked in the church, one student's father sold tais, and another student's father was a brick maker. People might also do unpaid work. Several teachers in Ponilala had volunteered to teach the free English course there. It appeared that these adults undertook the work because they believed in the importance of students learning English. I also interviewed a woman who worked as a catechist for ten years, taking responsibility for the church buildings adjacent to the Catholic school. She had also worked extremely hard in informal work to raise her many children (See Case Study on page 110). She stressed that this voluntary work was her decision; her task given by God (25/8/2019, Ponilala). 


\section{MOONLIGHTING IS COMMONPLACE}

Residents of Ermera often hold several jobs at once. Women's most evident work is housework and raising children. Many surveyed students would write 'my mother is [just] a housewife [3]'. However, in the interviews it became clear that the mother of teenage children might work on the family farm, run a kiosk, sell produce in the market, or have a formal job such as teaching nearby.

A young mother I met in Mirtutu on the hills overlooking Ermera vila taught at a pre-school just up the hill from her parents' house. She would help her parents on the family farm, and just down the hill she ran a small kiosk just down the hill, where she would sometimes sleep with her young son. She would also sell clothes, on market days in Ermera and in Gleno. I met another teacher in Ermera vila who moonlighted as a microlet driver between Ermera vila and Dili.

\section{THE AUSTRALIAN SEASONAL WORKER PROGRAM}

From conversations with three men in Ponilala, two of whom were teachers, I gathered that applying for the Australian SWP was fairly common. One teacher observed that the SWP was a good way to help Timorese citizens make a lot of money in a relatively short period. The SWP offers the opportunity to work in agriculture in Australia for far more money than they can in Timor-Leste.

The three men felt that there was a better and a worse way to use the six-month employment opportunity. They had seen returnees spend the money they had earned on a new motorbike or even a new car. Mr Felix felt that the cause of this short-term thinking was arrogance: '...some Timorese people are arrogant. They buy a new motorbike, car, good house, and they never think about education.' This would make them happy in the short run, but since they no longer had a sufficient income to maintain their vehicle, as soon as it needed repairs or as soon as they had no more money for petrol they would be left with nothing (interview, 25/8/2019, Ponilala). 
Other returnees spent their money on building a house (which might cost \$600). The brothers regarded this as a better investment.

The three men agreed that the best way to spend surplus earnings to use it to pay for going to university, or to start a business. For example, a SWP returnee might give money to support his younger brother or sister to go to university. The programme highlighted different attitudes toward education and employment: according to Mr Felix, some saw the SWP as confirmation that completing a university degree wasn't worthwhile: 'they get this opportunity and they think, "even if I don't get a degree from university I can still make money"' (interview, 25/8/2019, Ponilala).

Mr Felix used masculine pronouns when talking about returnees from the programme, but both men and women are selected for the SWP (Myat Thu and da Silva, 2013). Growing literature on the SWP and New Zealand's RSE scheme and their effects in the Pacific indicate some problems but also quite a few benefits, and the schemes are very popular (Bailey, 2013; Myat Thu and da Silva, 2013; Stanley (ABC), 2016; Dun et. al., 2018; Bailey, 2019; Chattier, 2019). The SWP is likely to continue, and become a progressively entrenched avenue of work for Timorese citizens.

It remains that the SWP enables Timorese nationals to earn a significant sum of money from working in agriculture for six months, and gives them the means of building a house or buying a vehicle, paying for university or investing in setting up a business. Returnees can also apply for work a second time. One former SWP worker who had spent six months picking strawberries in Tasmania during the harvest season told me that his name had been kept on the job roll of the company. He had recently been contacted by the company and essentially re-selected for the same six-month position. 


\section{THE SOUTH KOREAN GOVERNMENT}

A senior English teacher at a secondary ESTV school in Becora, Dili, told me about a recent Memorandum of Understanding (MoU) between the school and the South Korean government (Interview, 23/6/2019, Dili). The school offers Korean language to students, and some gain a high level of language comprehension through studying hard and capitalising on the opportunity to practice speaking with their Korean teachers, who fly over from South Korea to complete placements as part of the agreement. The MoU states that every year 200 students with the highest scores in Korean language will get chosen to work in South Korea for different companies. They typically work in a basic position doing some sort of technical work. While they have to wait until they're 20 or over, which might be a few years after they graduate, once they get work in South Korea they can stay for up to five years as part of an immigration agreement with the South Korean government, which handles their immigration. The minimum wage is high in South Korea has a high minimum wage and they can earn around $\$ 2,000$ per month, which is a lot, given a poor household in Ermera might earn just \$100 per year from farming (Interview with businessman, 25/7/2019; Gleno).

This programme is set to continue to the next five years. The Korean Government already has a strong connection with the school, and the technical college has recently been partly refurbished by KOICA (Korea International Cooperation Agency in Timor-Leste). The first batch of students were due to leave for their placement in South Korea of 2019 once they complete the final component of their technical training.

\section{AGRICULTURE AND ENVIRONMENT IN ERMERA}

As previously stated, of the 120 students surveyed in Ermera vila, ninety-nine of their parents worked in farming, and one student himself worked in agriculture to support himself. It seemed that nearly everybody had a farm or garden where they grew some produce. Many either had a coffee plantation or were involved in harvesting during the coffee season, along with selling produce, raising animals, or selling firewood. 
Family farms and gardens appeared to be a quiet affair. Aside from some tractors down in Gleno and a couple of watering systems on the slopes and roads near Ermera vila, farming appeared to be largely done by hand. One friend showed me a metal device near their house about the height of a letterbox which was used during some part of the coffee harvesting process. The air was clear, as the only fumes came from big trucks and bobcats being used for construction on the road leading into the town.

\section{SUBSISTANCE FARMING: A SAFETY NET}

According to Amo Deonildo, subsistence farming softens the annual boom and bust of the coffee season. Families often tell him that they have no money after using it for lia events, but this period of financial strain is eased because families can eat the produce that they grow at home:

'Some people say that for three months, coffee season, they have a lot of money, but after that it's a bit difficult. And that's why Father Lorenzo tried to tell people not to spend money on lia, as we need to save money for times like this. [But] in TimorLeste we have other things [to grow], like cassava and bananas, so I think in terms of money it's difficult, but for things to eat it's not too bad, fehuk, ai-farina, talas, kontas... [potato, casava, taro, arrowroot]...' (Interview, 4/9/2019, Ermera vila)

This confirms Hill's (2017) point that subsistence farming provides a kind of safety net for families, keeping them from starvation if money runs out. However, hungry season remains a very real part of life for poorer families (Howson, 2015, p. 1).

\section{COFFEE: A CENTRAL PART OF LIFE IN ERMERA}

Coffee is the cornerstone of life in Ermera district during the dry season. Plantations both small and large cover the $746 \mathrm{~km}^{2}$ area. There are small coffee plantations beside the path to Mirtutu, a village above Ermera village, which lie alongside family gardens and under large shade trees. Larger coffee fields lay along the five-kilometre road from Ermera vila to Ponilala. If a plantation is located far enough away from a family's home it will have a small, basic shelter where family members can sleep overnight in order to be able to spend full 
days picking, rather than trek the long way to and from home each day. Families will work as a team to harvest coffee ( $k u u$ kafe) during the May-August season, periodically stripping berries ranging from ripe to only partially ripe during an excursion to a plantation (interview with foreign volunteer, 13/9/2019, Mirtutu).

\section{LAND DEGRADATION AND A POSSIBLE SOLUTION}

Land degradation is a threat to future rural livelihoods. According to an agricultural businessman who has worked in Gleno since 2012, decreasing productivity in coffee farming is partly the result of deforestation and soil erosion (Interview, 25/7/2019, Gleno). Agricultural productivity is extremely low, and the soils in Ermera have been ruined by the past 100 years due to constant extraction and no care. Land clearing for crop planting, including with the slash and burn method, results in no ground cover. This leads to top soil being washed away during the rainy season, causing the ground to lose water, carbon and nitrogen. This is why agricultural productivity in Timor-Leste is extremely low, with coffee yields as little as one quarter of what they are in other countries, and coffee plants losing their leaves in the dry season. Low agricultural productivity and deteriorating agricultural conditions in the country might be ameliorated by the government formulating stronger policies and looking long-term. This businessman thought Timor-Leste might benefit from a programme similar to the Green Army project in Australia, where the government could pay youth to do environmental rehabilitation projects. Activities could include replanting, and putting a large volume of lime into a given hectare of land to reverse soil acidity, as TimorLeste has abundant lime deposits. Such a project would provided much-needed land rehabilitation at the same time as addressing high unemployment rates amoung joven. This would also make it a preventative step against potential future civil unrest in the mediumterm future due to high unemployment among the large youth population.

\section{GOING TO UNIVERSITY DOES NOT NECESSARILY LEAD TO A JOB}

Several people I talked to felt that completing a university degree didn't necessarily guarantee a job for graduates. The xefe suku of Mirtutu voiced this concern at a party I attended in September (informal conversation, 14/9/2019). He talked about the frustration of seeing young adults going to university but then returning to Mirtutu without having found a job. He felt that young people needed a kampu trabalhu ('job'). They could ask 
government parties for work, and they could also ask family members for a job. He understood that this approach was viewed negatively developed countries ('nepotismu'), but stressed that the situation in Timor-Leste was simply different. In places like Australia and America, young people would have gained useful knowledge or skills (matenek) through their education and be able to get a job, but in Timor-Leste, students might go to university and still not have gained matenek, so they might need to ask their family for help. Family was therefore the most important thing [4]. His last comment was telling: 'young people don't want to work in farming [5]'.

Helen Hill has observed that gaining a place at university does not guarantee that a student will graduate, as a large number of students drop out before completion (interview, 26/9/2019, Dili). There are various reasons for this, including families no longer being able to afford tuition. She believes the threshold for admittance into UNTL is very low, leading to large numbers of students attending classes, which impedes learning. In fact, UNTL may chiefly serve the important custodial role described by Reimer (1971) and Illich (1973): enrolling high numbers of students keeps them occupied and off the streets. Many school leavers also struggle at university because they are not equipped with the critical thinking skills and independent research skills necessary to complete coursework. UNTL does have a library at INFORDEPE ${ }^{51}$, but not many students go there. There are various institutions which offer free access to computers around Dili, but this knowledge does not appear to be widespread. ${ }^{52}$ Furthermore, UNTL does not have an adequate library for students to access sufficient learning materials. Students who do well generally use the Xanana Reading Room or free computers at the World Bank, neither of which are close to the UNTL campus.

\footnotetext{
${ }^{51}$ National Institute for Training of Teachers and Education Professionals (Tetun: Institutu Nasionál ba Formasaun Dosente no Profisionál Edukasaun).

${ }^{52}$ Based on my personal experiences helping a first-year university student, places with free computers include the World Bank, Human Rights Centre of the Social Sciences faculty at UNTL Kaikoli Campus, which includes a Health Science library; Fundacao Oriente; the Museum of the Resistence, the Xanana Reading Room; the Portuguese Cultural Centre; and the Knua Juventude Fila Liman inside Pateo Plaza.
} 
Hill had malae friends in Dili who financially support Timorese students to go to university: this was not uncommon. However, she thought that providing financial support alone was is insufficent to guarantee a student's success, and did not significantly reduce the chance that they would drop out. Academic support might include buying textbooks, helping with finding resources online or at places like the Xanana Reading Room, and properly referencing assignments.

This view fits with my observation of how helpful academic support can be for university students. In early 2019 I met a Timorese graduate who had received both financial and academic support from a malae businesswoman during her bachelor's degree in business studies over the last two years. The businesswoman had paid her tuition and provided support with proof-reading and some statistical analysis in her final-year thesis (monografia). This fresh graduate had run a profitable market stall during cruise ship season in the past year, and was currently applying for professional and academic opportunities overseas. The businesswoman sporadically employed her in her business, and was providing ongoing advice and support for her next steps. Relationships like these, however, are vulnerable to change; if support stops, the student is left in the lurch.

\section{THE MEANING OF DEVELOPMENT FOR EDUCATION AND LIVELIHOODS}

\section{'DEVELOPING THIS COUNTRY'}

Having examined the bases for the local economy and seen a diverse range of economic activities, it is now important to reflect on the concept of 'development' as it relates to local conceptions of desired futures.

During my research, I found continued references to 'development' (dezenvolvimentu), both during interviews with a student, a parent and a school principal, and at national level, from a high-ranking government official, and on television from national leaders like Xanana Gusmão. 
One student talked about how learning about being a role model and developing his public speaking skills could allow him to identify and address the problems in society and encourage others to address them in order to develop their country: 'It's really important for us to gain the skills ... to show others the right way and wrong way of doing things, in order to develop our country [6]' (Interview, 15/9/2019, Ponilala). Another interview participant, who looked after her sister's son, wanted him to grow up to be a good man, and find a good job in order to develop their country (25/8/2019, Ponilala). One mother of eleven thought that secondary education was not just important because it might enable her children to get a job, but also because it would provide them with the knowledge and skills to contribute to the future development of the country: 'I want our children to become educated in order to push Timor-Leste forward [7]' (25/8/2019, Ponilala). And Mr Felix talked about the SWP enabling workers to return home and build a house, which helped to develop the country: 'The house is for him, but the development is for East Timor' (25/9/2019).

On the other hand, Amo Deonildo spoke of the challenges brought by Ermera's contact with the outside world, and the risk that globalization would negatively affect Ermera communities. He believed that the 'development of mind', brought by exchanging culture with others outside the community, had an impact on social life in Ermera. He believed it was important to encourage students and young people to be proud of Ermera and of their Timorese identity and to know and respect one another, but at the same time be open minded and 'face the difference, development, [as] we have to face it in life [8]' (interview, 4/9/2019, Ermera vila).

At government level, 'development' is often referenced in relation to education. According to Director-General Antoninho Pires, the overall task of the MoE is to provide education, which serves as a platform from which people can gain the skills and knowledge to 'develop themselves, develop their families, and contribute to the development of the country [9]' (Interview, 19/9/2019, Dili). In 2018 the Minister of Education and Culture, Fernando Hanjam, when talking at a press conference said that the Ministry gives priority to education because 'education is the key to development' (GMN, 2018). In March 2020 the Deputy Leader of FRETELIN, David Dias Mundati, argued for the repatriation of Timorese students 
from China during the coronavirus pandemic because 'students are the future of the nation' (GMN, 2020j).

Education, students and young people are thus often mentioned in relation to development. However, I did not get a clear picture of what kind of 'development' was being referred from these interviews and news stories. What were participants referring to when they spoke of 'development'?

This question is somewhat clarified by an address given by Xanana Gusmão at a recent graduation ceremony. Gusmão was the face of the Resistance struggle against the Indonesian military regime, and his victory speech is a defining image of Timor-Leste's independence and its birth as a free nation. He enjoys widespread support and adoration by Timorese nationals, and his name can be seen scrawled on walls throughout Dili. He is arguably the most influential figure in the country: although his years as President (20022007) and Prime Minister (2007-2015) are over, he is still referred to as 'National Leader' on television broadcasts, and is popularly referred to as Maun Boot (big brother) by other politicians and Avo Nana (Grandpa Nana) by ema kiik.

In February 2020, Gusmão urged a graduating cohort in Dili to continue to develop their abilities and make efforts to share them with their society:

'You, the new generation, will become -' and here Gusmão prompted the audience's response - "the "drivers of development". It is you who will push our beloved country ahead. Follow the path of modernization, which gets its pace from economic and social progress [10]' (GMN, 2020d).

Rhetoric such as this, from an extremely powerful national leader, presumably trickles down from state- to community-level. It is reasonable to assume that this rhetoric on development and modernisation, combined with strong patriotism and a strong sense of collectivity, has influenced the aspirations and plans for the future of students and their parents. 
The spirit of charity, kindness and care for the community which guides the direction of Imacon School, through its Director and parish priest, appears to be both compatible and incompatible with this development rhetoric. On the one hand, the importance of the collective over the individual and the urge to serve one's community is apparent in both Gusmão's development rhetoric and the in teachings of Catholicism. On the other, as is evidenced in Amo Deonildo's comments, there is a danger that the strong communities of Ermera and their unique cultural heritage may be eroded by the 'individualising', homogenising, and modernising influence of globalization.

\section{CONCLUSION}

Teenagers living in Ermera subdistrict grow up surrounded by farms and gardens. As there are few formal job positions outside Gleno, the capital town of the district, most of their parents are farmers, and nearly all are involved in coffee production in the dry season. Across the country there is a large youth population, and the number of formal jobs is very limited. There are a range of alternatives, such as finding work overseas, and there is increasing emphasis on technical and vocational schools as a solution to job shortages. The economy, however, remains principally based on agriculture, and centuries of natural resource exploitation and widespread cultivation has taken its toll on the land. Many students are focused on going to university and do not want to work in agriculture, and yet agriculture continues to be referred to as the sector with the most potential. This paradox is reflected at state level. The government has shown itself open to environmental projects and policies, and yet leaders tout modernization as the goal which young adults should be striving for in their working lives.

The government wants 'development', teenagers want a university education and a job, and the land needs to be cared for and rehabilitated. It may be possible to reconcile these different desires and needs, particularly with the enthusiasm of young adults for their future, and their concern for their families and communities, along with the farming knowledge and interpersonal skills (discussed in the following chapter) that they have already developed during their teenage years. 


\section{Chapter 7: Education}

This chapter will provide an overview of education in Ermera subdistrict, before discussing the results of surveys with Grade 12 students and interviews with teenage students in Ponilala and Ermera vila, focusing on their perceptions of their education and their future aspirations. It will then discuss general themes arising from interviews with parents, teachers, principals and other professionals.

\section{BACKGROUND ON SCHOOLING IN ERMERA SUBDISTRICT}

There are five schools in Ermera vila. Escola Secundária Catholica Maria Immaculada Conceição Ermera, 'Imacon', is the private Catholic school that overlooks the market place, while Escola Secundária Geral Helio Sanches Pina Mau-Kruma Ermera, 'Mau-Kruma', is the public school, located ten minutes' walk down the hill. Imacon School houses Grades 7-12, while Mau-Kruma is for Grades 10-12 only. As of 2019 there were around 560 Imacon School students enrolled in Grades 10-12 and around 600 at Mau-Kruma School. Escola Presecundária 20 de Agostu Ermera, the public pre-secondary school, sits just above MauKruma School. There is also a government-run primary school located near Imacon called Ensino Basico Filial 303 Municipal.

There are another three schools in Ponilala: Escola Catholica Pre-secundária Catholica Padre Hilário Madeira Ponilala is the private Catholic pre-secondary school, Escola Pre-secundaria Geral 188 Ponilala is the public pre-secondary school, and Escola Basica 188 Ponilala is the public primary school. And there are many schools down the hill in Gleno.

In Ermera vila and Ponilala secondary school hours are typically divided into morning and afternoon sessions, with students attending one session or the other. This is a way of accommodating large (and growing) student cohorts within a limited number of classrooms, and also allows students to eat a midday meal at home before or after attending school. Pre-school and primary students typically attend school in the morning. 


\section{THE CURRICULUM}

Different collections of subjects are offered at primary, pre-secondary, and senior secondary levels.

The first two 'cycles' of primary school (eskola basiku in Tetun and 'SD' in Indonesian) Grades 1-3 and 4-6, are taught in Tetun, and include seven subjects such as Mathematics, Portuguese, Tetun, Religion and Art (interview with student, 25/9/2019, Ermera vila). Presecondary school, eskola pre-sekundariu or 'SMP', is considered the third cycle of basic schooling, and includes three further subjects: English, Civil Studies and Science (interview with D.G. Antoninho Pires, 19/9/2019, Dili).

At senior secondary level, eskola sekundariu or 'SMA', includes fourteen different subjects. Students can take new subjects such as Multimedia Studies, Malay and Indonesian, and Science is divided into Physics, Chemistry and Biology. Students must choose either the siénsias sosiais (Social Science) or the siénsias naturais (Natural Science) stream. All subjects are taught in Portuguese, with the exception of Tetun, Religion, Malaysian and Indonesian. Siénsias sosiais include Sociology, History, Themes of Literature and Geography, while siénsias naturais Physics, Chemistry, Biology and Mathematics. Students from both streams take Tetun, Portuguese, English, Civic Studies and Religion.

Exams are held three times yearly: in April to May; in July; and in either October (when Grade 12 students sit the Ezame Nasionál, the National Examinations) or November (for Grade 10 and 11 students) (personal correspondence with student, 28/4/2020).

A range of extra-curricular activities are offered at Mau-Kruma and Imacon Schools. At Mau-Kruma School, students can participate in public speaking and enter competitions, including for Portuguese, English and poetry oration, sometimes involving travel to Gleno or Dili. Sports are also offered: football for boys and volleyball for girls, although a girls' football team has recently been set up..$^{53}$ I also observed martial arts classes held on the

\footnotetext{
${ }^{53}$ The Director of Mau-Kruma School confirmed that the creation of the team was to promote gender equality, and one of students who had joined the new team saw it as part of a wider change
} 
school oval in the afternoons. Additionally, students have the opportunity to organise school events on nationally observed dates holidays. One student told me she usually led a flagraising parade on 20 September, the date marking the 1999 arrival of INTERFET. On another national day, 30 August, ${ }^{54}$ student committees organise special activities such as a tug-ofwar, a cooking competition, and sport (personal observation). Imacon School runs a similar range of special activities after each exam period, which include a traditional cooking competition, cultural dance, traditional drumming and sports competitions. Extracurricular subjects include basketball, volleyball, football, cultural dance, science competitions and public speaking. There is also a school band. As a private school, Imacon School is better financed ${ }^{55}$ with visibly better infrastructure. Imacon School students can also participate in fundraising and community service activities outside class hours. ${ }^{56}$ At Easter time, the money raised is used to buy basic food items such as rice, oil and superme for vulnerable members of the community (ema kbiit la'ek), and students help these residents in other ways, such as improving their housing, collecting firewood or water, or helping in their gardens. Amo Deonildo explained that this was part of instilling a spirit of charity in students and encouraging them to care for and give support to their community. Amo Deonildo also runs Christian youth camps, which students have the opportunity to attend (4/9/2019, Ermera vila).

\section{SURVEY AND INTERVIEW RESULTS}

I conducted 120 surveys with Grade 12 students at Mau-Kruma and Imacon schools, and interviewed eleven students (six girls, five boys) on their view of their education and on what they wanted to do in the future. The interview participants were all aged between sixteen and eighteen, while survey participants were aged between sixteen and twentythree.

in Timor-Leste regarding girls and gender equality (agora iha mudansa uitoan iha Timor-Leste). (3/9/2019, Ermera vila). Imacon School is also in the process of creating a girls' football team. ${ }^{54}$ The national holiday marking the date of the 1999 Referendum, Loron Konsultasaun Popular. ${ }^{55}$ Students pay $\$ 5$ per month to attend Imacon School, rather than $\$ 3$ at Mau-Kruma School.

${ }^{56}$ For example, students collect empty bottles and cans to raise money. A depot in Dili accepts aluminium cans in exchange for a small payment (which is around $\$ 1$ for a big bag of crushed cans. The amount may be only around $\$ 0.25$ in the districts if a middleman buys cans from rural residents and transports them to Dili to make a small profit and cover fuel costs). 
QUICK STATISTICS FROM SURVEYS

Table 7: Gender of Survey Participants

\begin{tabular}{|l|l|l|l|}
\hline School & Boys & Girls & Total \\
\hline Mau-Kruma school & 24 & 44 & 68 \\
\hline Imacon School & 23 & 29 & 52 \\
\hline & Total boys: 47 & Total girls: 73 & Total students: 120 \\
\hline
\end{tabular}

Table 8: Number of Participants per Stream in Each School

\begin{tabular}{|l|l|l|l|}
\hline School & Social science & Natural science & Total \\
\hline Mau-Kruma school & 37 & 31 & 68 \\
\hline Imacon School & 35 & 17 & 52 \\
\hline & Total: 72 & Total: 48 & Total students: 120 \\
\hline
\end{tabular}

Figure: Age Range of Grade 12 Students

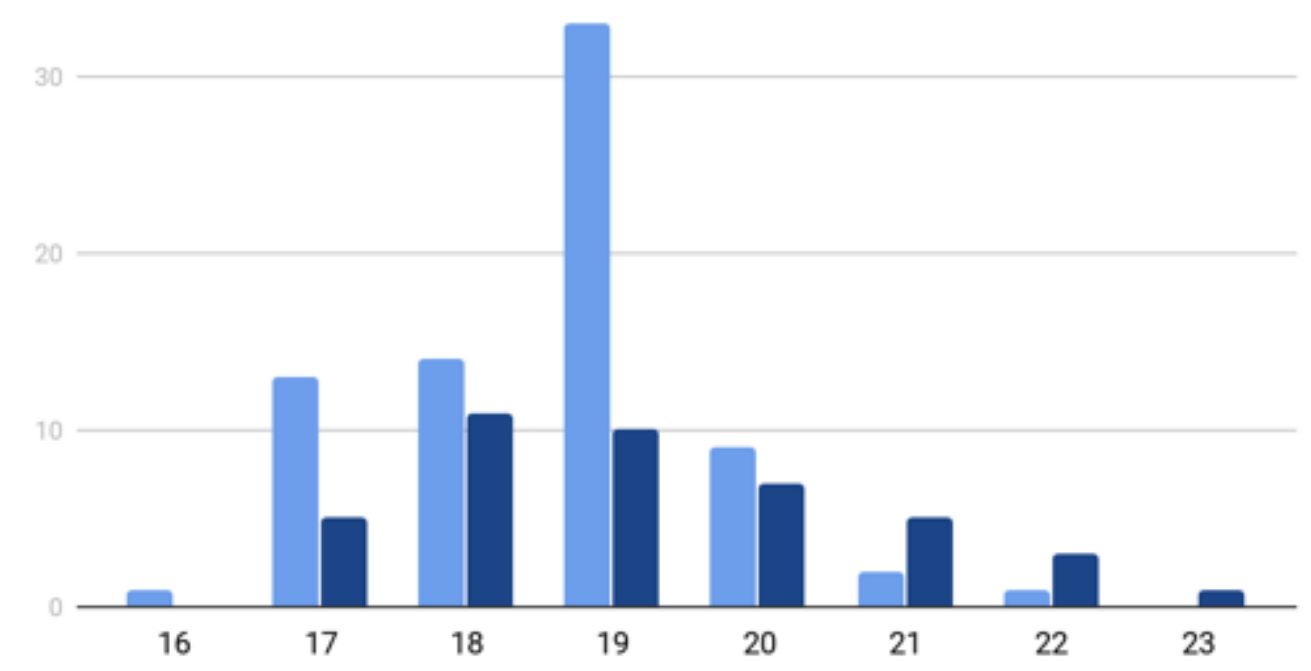


Figure: Where Students Were Born Compared to Where They Currently Live
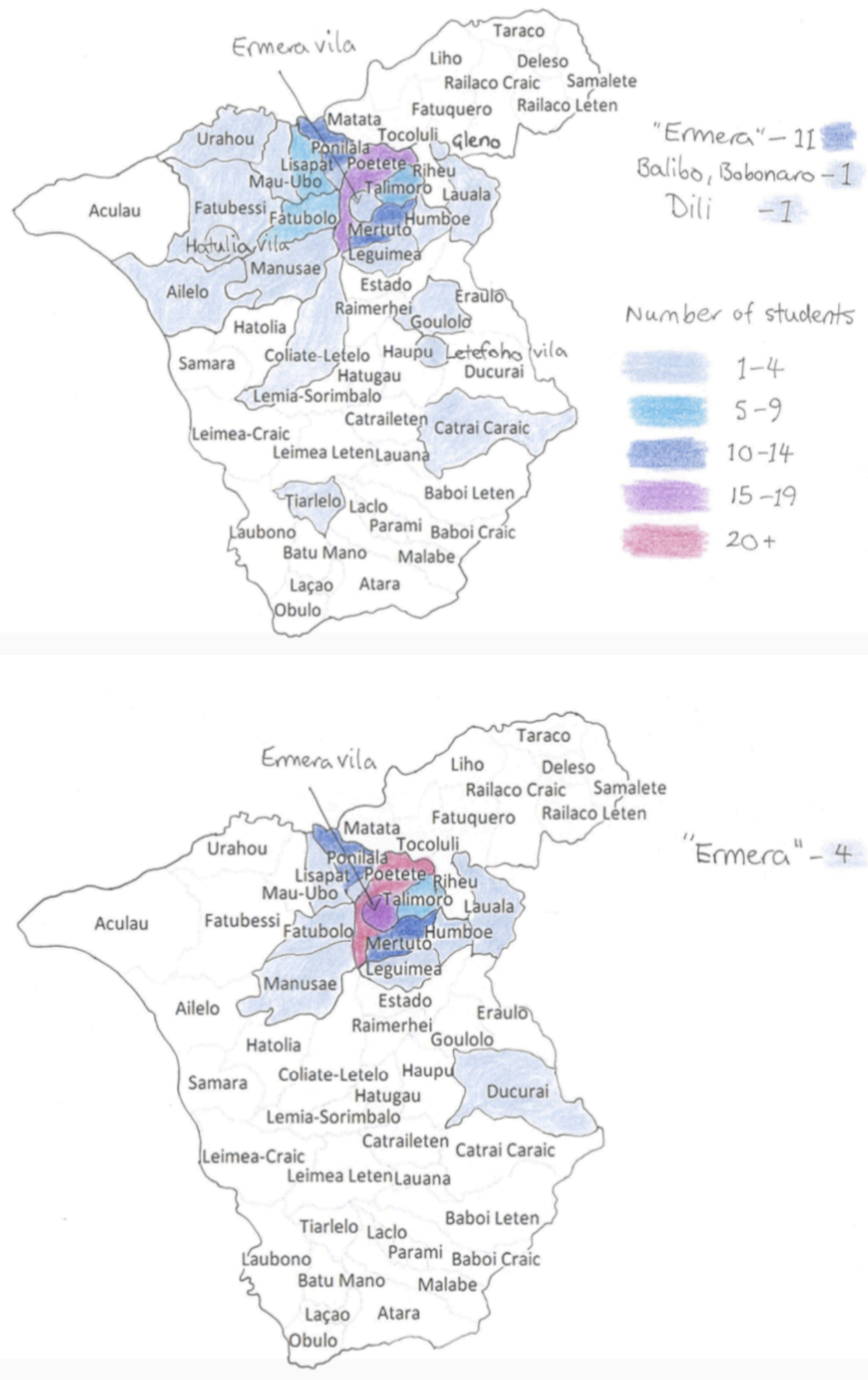

Top: students' place of birth; bottom: their current residence. These results show a degree of migration inward toward the two secondary schools in Ermera vila. Some students merely recorded 'Ermera' as a location, which may refer to the subdistrict or the municipality. Dili refers to the capital city, and Balibo to the town in Bobonaro municipality. 


\section{STUDENTS' PERCEPTIONS OF SCHOOL}

I asked students for their views on their secondary education. They all gave positive accounts, ${ }^{57}$ although one teenager highlighted the long distance he and his friends had to travel to and from school in Ermera vila: 'I think our secondary education is good, even though every day we walk to school, it's far from here...' (interview, 15/9/2019, Ponilala). Some students felt that secondary school 'increased their knowledge', building upon what they learned pre-secondary school. One viewed education as important as it enabled them to learn to read and write. Three students talked about the range of school activities they could participate in at secondary school, including sport, competitions, debating, cultural dance and traditional cooking and community service.

One student appreciated the opportunity to learn more from newly-arrived teachers and from fellow classmates. For another,

'Secondary schooling builds upon what we have learned at pre-secondary school, and we learn how to speak, to be more self-confident, and most importantly we learn about the Sciences [11].' (15/9/2019, Ponilala).

An Imacon School student saw the 'acts of charity' (asaun karidade) which students could be involved in at Imacon School as valuable both because helping others in need was important in itself, and because it taught him more about life.

One student from Ponilala thought it would be best if her suku had a secondary school:

'In this way joven could go to school nearby... and the school shouldn't be expensive, so that parents who don't have much money can support their children to go there [12]' (15/9/2019, Ponilala).

\footnotetext{
${ }^{57}$ It is possible that other students did not feel comfortable sharing less positive views of education, perhaps because I was accompanied and assisted by an English teacher and friend during most of the nine student interviews in Ponilala, and because I myself was seen as an English teacher. However, it also appeared that being positive and upbeat was a norm in Ermera subdistrict, at least towards a foreigner like myself, and negativity or criticism was avoided. Either or both may be contributing factors.
} 


\section{STUDENTS' FUTURE PLANS AND ASPIRATIONS}

Virtually all the 120 students surveyed wanted to either go to university or attend a course (kursu) after they graduated from high school.

Table 10: What Grade 12 Students Want to do After Finishing Secondary School

\begin{tabular}{|l|l|}
\hline Response & Number of students \\
\hline $\begin{array}{l}\text { Go to university } \\
\text { Plan mentions university }\end{array}$ & 76 \\
\hline Take a course & 82 \\
\hline $\begin{array}{l}\text { Plan involves going to university or taking a } \\
\text { course }\end{array}$ & 25 \\
\hline Enter a seminary & 5 \\
\hline Pursue a specific profession & 3 \\
\hline Make a school garden & 3 \\
\hline Vague answer & 2 \\
\hline
\end{tabular}

A more detailed table of survey participants' responses can be found in Appendix 7.

Of the eleven students interviewed, all except one wanted to become a teacher, journalist, doctor or nurse. Ten wished to attend university, and five of these ten emphasized that they wanted to attend UNTL. Ten attended either Imacon or Mau-Kruma Shools, and one was enrolled in Grade 9 at the Ponilala Padre Hilario School (for detail, see Appendix 7).

Most students had clear reasons for pursuing their desired future profession. For one student, his dream to study Medicine at university and become a doctor was financially motivated as he wanted to help support his family in the future, particularly his younger siblings. Another student, who also wished to study Medicine at university, wanted to become a nurse in order to help sick people. One student wanted to become a journalist so that she could take photos as part of her job, and learn about internal affairs within TimorLeste, as well as about international news. Another student wanted to become a journalist 
too so that he could visit and learn more about life in other countries, and conduct interviews.

Students' favourite subjects at school often, but not always, related to their future desired professions or to what they wanted to study at university. For example, the student who wanted to become a nurse liked her Mathematics at English classes at school. This was because she wanted to study Medicine at school, and for this she needed to be able to count. She had wanted to study English at school in order to qualify for a scholarship. Of the four students who wanted to become teachers, three wanted to teach English. ${ }^{58}$ Two of these three told me that English was one of their favourite subjects. One student enjoyed her Geology classes at school, and wanted to take Geology at tertiary level, although she also wanted to take Medicine and then become a doctor. One student, whose favourite subjects were Biology and English, particularly enjoyed his Biology classes because he liked learning about the natural world. He wanted to learn more Biology at tertiary level and then become a Biology teacher.

Some students were clearly thinking about the high financial cost of university. One was aware that getting into university was dependent upon his parents' financial position. Another had factored this financial hurdle into his plans: if his parents were unable to pay for his university tuition he would need to work in Dili, for example in a shop, in order to pay tuition himself. His parents were both farmers who sold produce and raised animals to earn a living, and had ten other children.

Two of these students' future plans appeared quite mutable. In personal conversations prior to the interviews, two students I spent time with talked about wanting to become teachers. One also talked about his ability to teach classmates and younger children, and I saw this in action one day at the free English course. However, when I interviewed him he talked about

\footnotetext{
${ }^{58}$ Note on student responses regarding English language: It is possible that students told me that their favourite subject was English, or told me that they wanted to become English teachers, in order to please me in some way. I am a native English speaker and most students viewed me as an English teacher, especially those who attended the free English course run at Ponilala or saw me assisting in English classes at school.
} 
his wish to study Medicine at university and become a doctor. This may have been because teaching, while a respected profession, is not highly paid, and he wanted to gain a greater capacity to help support his family. The student with a passion for Biology and who wanted to become a Biology teacher is now enrolled in Medicine at university, and also planning to become a doctor.

Some students were considering a couple of different future work paths. One wanted to either study Medicine at university to become a doctor, or study Petroleum to become a director in an oil-related company. One of the students who wanted to pursue journalism also wanted to become a musician if she had the time and the money to buy a musical instrument such as a guitar. Another was thinking of several different professions: she wanted to become a journalist, join the police or the military, or become a footballer. A student who wanted to take Philosophy and English at university and teach English was also clearly keeping his options open, as he had just returned from applying to a seminary in Dili.

One student's future plans diverged with those of her father:

"I want to go to university, but my issue is that there are a lot of subjects I want to choose, but I can only choose one... and my father wants me to become a nun [laughs], but I just don't know yet [13]' (15/9/2019, Ponilala).

This student wanted to do something else, such as become an English teacher.

Some students had more general aspirations for their future life. One student, who loved motorbikes, was enthusiastic about saving up to buy one. Other students' general aspirations were related to family. One student, although he wanted to live away from family while attending university in Dili in order to gain some life experience, ultimately wanted to use what he learned at university in order to work hard to afford medical treatment for his father, who was sick, so that his father would return to good health and be able to work again. One wanted to finish university and obtain work, and then live with her family in Hatolia subdistrict. She wanted to earn a bit of money and perhaps buy a motor so that she could go on trips with family members during holiday periods. Another student 
wanted to move to Dili after she finished secondary school in order to live with her brothers and sisters.

These eleven students held quite diverse and ambitious aspirations. As with the Grade 12 survey participants practically all of the students interviewed wanted to attend university. They often gave clear reasons for the future work and study they wanted to undertake, and some had more general aspirations related to their future life which often related to family. Virtually all felt that education had the potential to allow them to obtain their desired future profession, and none wanted to be farmers, which was the profession of the majority of their parents.

PARENTS' PERCEPTION OF EDUCATION AND THEIR ASPIRATIONS FOR THEIR TEENAGE CHILDREN

All nine parents I interviewed had a positive view of education, and felt that secondary education was important. Some felt that it would shape their children's future for the better, while others talked about its relationship with the nation's development. Many viewed secondary education as a vital stepping stone towards university.

Two fathers viewed education as a key determinant of their children's future. One felt that secondary education was very important for his children's future because it not only increased young people's knowledge [14] but also determined whether or not they could study at tertiary level, which in turn determined their future success in the future [15]. The other father viewed education as a key shaper of a person's future, and as a path toward obtaining a good life. For their part, his children wanted to continue their study, and for this reason he needed money, although as a farmer his means were limited. Money was a pressing concern. Outside wanting his children to have a good life and be educated, he did not mind what work his children obtained in the future: 'I will follow their wishes [16]' (25/8/2019, Ponilala). 
Two parents discussed the role of education within the wider context of the country's welfare, and viewed their children's education as equally, if not more important, as their future employment. One mother wanted her children to learn more at school in order to become educated and get a good job, as well as to contribute to Timor-Leste's development in the future [7]. She and her husband worked hard to send all their children to school to prevent them from remaining uneducated like their parents: if their children did not become educated, she and her husband would feel that they had failed in their duty as parents. Her five eldest children were either still at university or had graduated, and had not yet found work. Another woman hoped that, through education, her adopted son would find work and help to develop the country. Similarly, a xefi aldeia who lived nearby thought that secondary education was very important, and the older generation (himself included) viewed education as a priority because it was the 'future of the nation [17]':

'Education is important, it's an important key for this nation. One could say that if you don't have education, what will become of the country? This is why we farmers work to earn money, and why our children must go to school whether they want to or not, because education is important, and the key to the nation is education [18].' (25/8/2019, Ponilala).

The xefi aldeia believed that education was important for his children's future, and that it was important for them to continue their schooling at secondary level in order for them to find work and earn money. The most important thing was for his children to pursue their education: He didn't mind what kind of work they obtained in the future, and even if they didn't find work he and his wife would still be grateful that his children had gained an education [19].

The parents generally felt that it was important for students to attend university. To one father, the purpose of secondary education was to equip students with the necessary 'knowledge' (matenek) for them to attend university in the future [20]. Education was also important in a general sense: 
'Education is important because it brings knowledge of the world and teaches people how to love others. People gain knowledge of the world through gaining knowledge of others. And through education one learns how to love others [21]' (25/8/2019, Ponilala)

Another father, who worked as a school coordinator, felt that a teenage relative who they were looking after was receiving a good education, but believed that finishing secondary school was not enough, and it was vital that students continued to university to 'gain more knowledge'. He believed education was important because it could change people, enable them to analyse their behaviour and tell right from wrong: 'without education, our brain is darkness'. (25/8/2019, Ponilala).

\section{Case study: 'God gave me the confidence to support my family, and now I can rest.'}

One mother had brought up her ten children plus another five adopted children. The youngest was now twenty-three. She worked extremely hard to bring up all her children, and, later, to pay their university tuition fees. She worked in agriculture, selling produce, raising animals and farming coffee, and also running a kiosk. 'At night I didn't sleep, I was always thinking of how to get money to support my children' (Interview, 25/8/2019, Ponilala). She clearly felt that education was important and worth working very hard to pay for. Her husband had worked as a teacher, earning around \$120 per month from 2002 until his death in 2011. The following years as a single parent must have been particularly challenging. Thirteen of her children had now all finished their study: five were teachers, including one at Imacon School; three worked in agriculture; two sons were doctors; one worked for an NGO; one was a nun and another was a priest. One was studying to be a doctor, and another was studying in Indonesia, intending to become a nun. Now she could finally rest, as her children were supporting her in turn, buying her food and building a house for her as she continues her voluntary service as a catechist at the Church further up the hill from her home. 


\section{SCHOOL DIRECTORS' VIEW OF EDUCATION}

It was clear that both senior secondary school directors in Ermera vila were dedicated to delivering effective education to students and improving students' educational experience.

Director Martins gave an overview of what past students of Mau-Kruma School went on to do for work. Since he began working at Mau-Kruma in 2015, Director Martins had observed that many students go on to university. Many have established their own NGOs. Some have attended courses in South Korea and Australia; learnt English in order to go to Ireland or Britain; or learnt Japanese in order to go to Japan. Director Martins thought that generally about $40 \%$ of students enrol at university, $40 \%$ enrol in a course, and the remaining $20 \%$ do not enrol in either. Those who go to university attend many different universities in Dili: DIT, IOB, UNDIL, UNITAL, UNPAZ ${ }^{59}$, UNTL, and any also enrol in ETCI, the agricultural institute in Gleno (Interview, 3/9/2019, Ermera vila).

For his part, Amo Deonildo saw the need for students to think outside the box when considering their future work options (Interview, 4/9/2019, Ermera vila). He observed that students tended to aim for a narrow range of formal positions - particularly doctors and nurses - along with the jobs they saw in their immediate context. He wanted his students to be aware of all the potential job and training options available to them: things like interior design, cooking, building houses, tourism, were also options, but there was not much information readily available to students on these pathways, so they did not have much knowledge of these kinds of professions. Learning a practical trade like carpentry might also be a good investment, as there would always be a demand for builders across the country.

Amo Deonildo made an effort to gather information on scholarships, not just for his current students, but also for past students, in order to continue to support their endeavours. He was arranging for alumni who had gone on to university; to South Korea or Australia, or become doctors, to come back to the school at the end of the year and talk to current students. These alumni, who had attained good positions typically in Dili, would be able to

\footnotetext{
${ }^{59}$ Dili Institute of Technology; Institute of Business; Universidade de Dili; Universidade Oriental Timor Lorosa'e; and the Universidade da Paz.
} 
share their knowledge with students, and help to inspire them. The doctors, for example, could give them information on nutrition. This was part of the 'spirit of service' that Imacon School teaching staff tried to teach all students: to contribute to their community with the skills they had, rather than to merely finish their schooling and leave.

'When we look at the students, we see the future. And we try to facilitate that. We run things like the computer course to try to make that future bigger, to help them.' (4/9/2019, Ermera vila).

\section{ANALYSIS OF SURVEY AND INTERVIEW RESULTS}

Amo Deonildo's comments generally match the results of the interviews I conducted with students: most wanted to become a nurse, doctor or teacher. There were some exceptions, however, as two wanted to become journalists, and another was considering a range of different work paths, including the police force or military. One wanted to work as a musician alongside a more formal job, and one was considering the chance of gaining work in the petroleum industry. Some students were weighing up different work paths, keeping their options open and pursuing subjects they were interested in, as well as thinking about where they might like to live or how they could support their family.

Students and parents alike had a positive view of secondary education, and both the surveyed and interviewed students overwhelmingly wanted to attend university after finishing secondary school. Many parents I spoke to hoped that their children would attain a good job in the future, and viewed education as a path to a better life, and some hoped that it would enable their children to contribute to the country's development. In the immediate term, their finances (ekonomia) were their main concern, and at least some teenage interview participants were aware of this, in relation to their wish to study at tertiary level.

Several parents were not merely focused on their children completing their secondary education, but also on them completing a university degree further down the track. One said explicitly that secondary education was not enough, and students needed further education to increase their knowledge. In rural Ermera, where many families are very poor and already struggle to send their students to high school, it seems a cruel burden for 
families to feel they must also raise the money to send their children to university, which is still more expensive, in order to improve their children's future prospects. Ideally students would be able to graduate from twelve years of schooling with the literacy, numeracy and basic critical thinking skills needed to find work in their country without having to complete yet another qualification in order to be seen as educated and employable. In a country which is still working towards providing universal basic education it seems counterproductive for all students to be pushed into tertiary study when they will not necessarily find work afterward, particularly well-paid work, as their families may already be struggling to make ends meet.

\section{SKILLS}

During the interviews, I asked teenage students what they thought was the most useful skill they had learned in the past three years. If the students were initially confused or hesitant I would clarify that the skill could be anything that they used a lot and that was useful to them, either at home or at school. I also asked professionals such as teachers, school directors, high-standing officials and other professionals engaged in education and agriculture for their opinions. Overall these professionals stressed the importance of students obtaining the kind of practical trade and vocational skills which are needed everywhere, with which they could find work, including overseas, and with which they could use to create their own work. One hoped students might learn a practical skill in order to help their society. Several felt that English language would be useful to students. Farming, communication, and public speaking skills, along with the capacity to learn independently and be creative, were also recommended.

Several students did cite public speaking and English language skills as the most useful skills they had gained in the past three years. Most felt that interpersonal skills, including conflict resolution, explaining to or teaching others, the ability to work in a group, communication skills, and leadership skills were useful to them, as well as the ability to learn independently. One student mentioned self-sufficiency, while two others viewed the ability to apply what they learned in school to their society, such as helping vulnerable community members, as most valuable. (For detail, see Appendix 7.) These students generally had excellent 
communication skills: most appeared articulate, confident, driven, had strong connections with their peers and saw the value of interpersonal skills for completing work successfully and being able to help others. While none mentioned practical or technical skills, the survey and interview results show that the majority of teenage students are engaged in farming work at home, such as growing vegetables. Furthermore, given the small but significant number of carpenters in the community, some boys may have learned a bit about building from their fathers. These are practical skills. Overall, the interviews revealed thoughtful young adults with a concern for others and a desire to learn more as they pursued their desired profession.

\section{CHALLENGES TO STUDENTS' SECONDARY SCHOOLING}

\section{OVERVIEW}

The surveys and interviews I conducted, along with informal conversations and personal observations, revealed various challenges to student learning at secondary school level. This included student disengagement and non-attendance; financial hardship; the distracting effect of the internet and social media; long distances to school causing poor concentration; late and absent teachers; and an overreliance on rote learning as a teaching method. The former Portuguese and Indonesian administrations continue to influence the education system, including through language and discipline. There is often a disjuncture between learning in classrooms and students' daily experiences, although there are moves to bridge this common gap at both local and government level.

\section{PRIORITIES AMONG EDUCATORS IN ERMERA SUBDISTRICT}

It is clear that many teachers and school principals are dedicated to providing relevant, quality education to their students. Offering computing courses is a current objective for educators in both Ermera vila and Ponilala. While Imacon School already offered Computing as a school subject, and teachers in Ponilala were currently envisaging being able to set up computing courses for teenagers and young people in the future (Interview with Mr Felix, 25/8/2019, Ponilala). Director Martins talked about his aspiration to run English, Computing and Leadership courses for students at Mau-Kruma School so that they would not have to travel to Gleno in order to attend one (Interview, 3/9/2019, Ermera vila). Expanding English 
language resources was also a priority across the subdistrict. During my time in Ermera, the Imacon School Director was exploring the possibility of establishing an English Language Centre (ELC) in Ermera vila with assistance from the Friends of Ermera group: this group had recently assisted the establishment of an ELC at NCES in Gleno. Meanwhile, teachers in Ponilala have been running the free English course for several years.

What stands out is the active, dedicated way in which teachers and principals are seeking to equip students with the skills that might maximise their chance of finding work as they become adults. However, there remain several challenges to student learning in Ermera subdistrict.

\section{STUDENT DISENGAGEMENT AND NON-ATTENDANCE}

During my stay in Ermera, various students and teachers mentioned the many teenagers who are disengaged from their learning or do not attend school at all. Educators viewed the use of the internet and social media as a contributing factor (see Appendix 6).

When I asked a student from Ponilala whether there were other young adults in the suku who did not go to school, she replied:

'Yes, in Ponilala there are a lot who don't go to school because their family can't afford it ... there are also some families who have enough money, but they don't want to push their children to go to school [22]' (Interview, 15/9/2019, Ponilala).

According to this student, many of these young adults just hang around at home (halimar), while others help their parents in the farm or garden.

Besides limited family resources, there are several other factors which may contribute to this disengagement and non-attendance. 


\section{DISTANCE TO SCHOOL AND TROUBLE WITH CONCENTRATION}

Students' trouble concentrating at school may be due to the long distances they must travel to school; hunger; or not drinking water during school hours. During casual conversations students from Ponilala would tell me about the long walk they had to make to school each day. This was confirmed by Mr Felix:

'Their home is far from school, one hour, or one-and-a-half hours, so when they reach school they may have already lost their concentration during their first class. They're a bit tired, a bit sleepy. It's a problem.' (25/8/2019, Ponilala).

As noted in Chapter Five, students' difficulty concentrating may be due to hunger. As already described, one student told me about periods where he would have no evening meal, as his family was large and his father eked out a living in farming alone. Parents may struggle to feed their families, particularly during the hungry season. Access to potable water, and water at all, is an ongoing issue across the districts. I never saw students drinking water at school, so dehydration may also be impeding students' ability to learn effectively during school hours.

\section{LATE AND ABSENT TEACHERS}

Teacher absenteeism is a challenge in schools (World Bank, 2013). During my time in schools it seemed that teachers were often absent at short notice for reasons such as travel for their personal educational activities; teaching at other schools; the death of a family member; or errands related to proposals or funding for the school. It appeared that teachers were expected to hold make-up classes for ones they missed, but it was unclear whether there were any consequences for not doing so. Additionally, teachers typically turned up late to classes, arriving half an hour or more after the official start of school, and often entering the classroom late after intervalhu. ${ }^{60}$ The Minister of Education has called for school staff, parents and students to work together to ensure teacher absenteeism does not go unmentioned (GMN, 2020g). According to one teacher and NGO staff member, teachers are

\footnotetext{
${ }^{60}$ Brief recesses between classes.
} 
not paid enough and receive little teaching or general support at schools, which lowers their motivation to put effort into their teaching activities (30/3/2020, Wellington).

\section{ROTE LEARNING}

Rote learning dominates teenagers' schooling in Ermera subdistrict. ${ }^{61}$ At Mau-Kruma and Imacon Schools I chiefly saw students copying down notes from the blackboard into their notebooks; listening to the teacher; or waiting for the teacher to arrive. Teachers would often assign students to copy sections of the textbook onto the board, which the other students would in turn copy into their notebooks for the majority of the lesson. According to one teacher, schooling in Timor-Leste is still very grammar-focused, which is a remnant of the Indonesian school system. She felt that students needed to spend more time learning by doing, be given the space and the opportunity to explore the world around them, and be encouraged to imagine, create and reflect (30/3/2020, Wellington). Helen Hill also felt that there was too much of a focus on memorization and rote learning. The National Examinations, for example, are based on multiple choice, which does not test student learning effectively. By contrast, including something like an individual project in students' final year in the curriculum would allow them to learn by doing and creating (interview, 19/9/2019, Dili).

\section{LANGUAGE}

Students grow up in a multilingual environment: most speak at least a couple of different languages in their day-to-day lives. Whilst volunteering at one English class, I observed the teacher giving explanations to the students in a combination of English, Portuguese, Tetun and Indonesian, and probably also in Mambae. This multiplicity of languages can make schooling rather confusing, and students have different levels of competency in different languages across Timor-Leste (World Bank, 2013). Mambae is most Ermera residents' first language, although one student told me that her family actively prevented her using Mambae, a decision made by her grandmother. Her parents and grandparents would speak

\footnotetext{
${ }^{61}$ The NGO staff member, who also works as a preschool teacher, informed me that small children tend to learn by memorising numbers and letters, and in the first few years of schooling they tend to learn the same content each year rather than the content being expanded upon. 30/3/2020, Wellington.
} 
to her in Tetun when she was growing up, only speaking Mambae among themselves. This was to help her excel at school. Consequently, she was fluent in Tetun, but could only understand some Mambae, and could not speak it (Interview, 25/9/2019, Ermera vila).

\section{'TAUK SALA': AUTHORITY AND DISCIPLINE}

When I interviewed a pre-secondary school student he mentioned the shyness (moe) and fear (tauk) of his fellow students which prevented them from speaking up in class. When prompted he explained that students are often afraid of making a mistake, and so keep quiet [23]. This suggests that students may be scolded or punished for making mistakes, which disuades them from asking questions, and consequently impedes their learning. A teacher from Dili explained that the use of violence as a teaching method is normalised both inside and outside schools (Interview, 30/3/2020, Wellington). The enduring authoritarianstyle discipline and use of corporal punishment has its roots in Timor-Leste's colonial history. ${ }^{62}$ According to the teacher, most parents and teachers have grown up in Portuguese and Indonesian times, where the use of violence was a standard teaching method, and many experienced traumatic punishments doing schooling. As a result, many believe that the way to gain respect from students and children is through violence, which leads to students not being treated with respect or encouraged to ask questions and communicate effectively.

The use of motivational talks in classrooms as a way to encourage student learning may constitute a move away from this older, more punitive style of teaching. One of the teachers I assisted would often give five or ten minutes of motivation for the students at the end of the lesson. I witness two other teachers taking a similar approach, urging their students to study hard in order to improve their future prospects. Amo Deonildo's plan to bring back past alumni of Imacon School to inspire current students runs in the same vein. This newer approach may have arisen from sources such the pedagogy and ethos of SOLS, given that many teachers will have had contact with these centres. ${ }^{63}$

\footnotetext{
${ }^{62}$ Hill $(2007$, p. 15) explains that corporal punishment as a teaching method has been compounded by humiliation rituals for incoming students, which are a legacy of the Indonesian system.

${ }^{63}$ Rose, 2019: Other possible sources are Catholic pedagogy; standard INFORDEPE seminars; and educational training by Ba Futuru.
} 


\section{DISJUNCTURE BETWEEN STUDENTS' EVERYDAY LIVES AND SCHOOL MATERIAL}

Another reason for student disengagement in class may be that lesson content is often detached from students' daily experiences. As mentioned in Chapter Four, Dr Rui Araujo (2016) has highlighted the 'major disconnect between school material and its application in daily life' as a key issue within the education system. A former high school science teacher agreed, and believed that student disengagement was due to teachers not making an effort to link lesson content to students' everyday lives and experiences (Interview, 30/3/2020, Wellington). The English material I saw in Mau-Kruma and Imacon Schools, which was based on the same set of MoE-issued textbooks, was often detached from students' lives, which visibly impeded learning. Topics ranged from sports which students might never have heard of let alone played, to creating a job advertisement based on an adventure course tour guide, to a description of a wedding in Tanzania: both students and teachers found the last two particularly challenging. The 2016, 2017 and 2018 English National Examination papers, which Imacon School had obtained to use as preparation material for Grade 12 students, contained similar disconnects. For instance, one exam paper covered waste disposal and recycling, despite there being no recycling system in Timor-Leste other than for aluminium cans, and there being little awareness of the impact of plastic on the environment, particularly outside Dili.

However, there are various moves to better connect student learning with their daily lives, especially their cultural heritage, both within the schools of Ermera vila and further afield. I saw the results of a group practical assignment which was linked to local culture at MauKruma School. the teachers' staffroom at Mau-Kruma School. There were two beautifully constructed models of uma lulik (sacred houses) at eather side of the staffroom. One of the teachers explained that they had been made by the Grade 12 Social Science cohort and the Natural Science cohort respectively. As mentioned at the start of the chapter, Imacon School has incorporated aspects of traditional culture in Ermera into extracurricular and holiday activities, and one of its central aims to situate student learning within their community through acts of service. These are clearly 'decolonising' moves, which give traditional knowledge and local values centred on community, sharing and connectedness a place within students' education. These local values appear to be compatible, or have merged, with Christian Catholic principles, highlighting the fact that 'local', 'indigenous' and 
'traditional' are fluid and porous categories rather than static phenomena. Further incorporation of learning on how to build houses and tais cloth from parents and grandparents (Hill, 2007, p. 4), along with ai-moruk (traditional medicine), animist beliefs and even black magic within the current Western-oriented curriculum could legitimise these skills and epistemologies and preserve Ermera's unique heritage. Vulliamy's (1981) investigation of similar efforts to centre student learning within rural communities through focusing on practical skills as much as Western academic learning could provide a template. Amo Deonildo, as a school director and a priest, also works between Catholicism and animist beliefs, acknowledging and respecting both. ${ }^{64}$ These examples at the two schools suggest that a decolonised education system based upon both Timorese indigenous culture and on Catholic faith is more than just an ideal: it could be a reality.

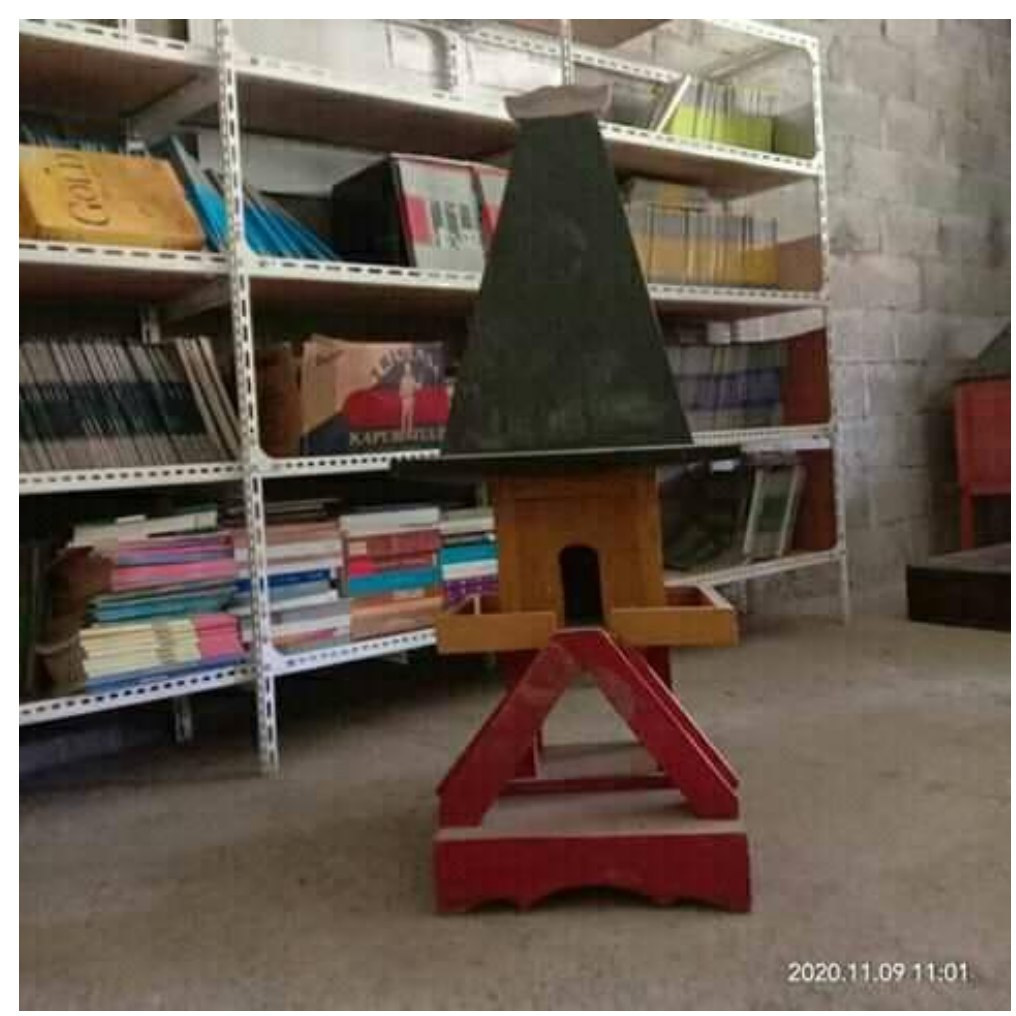

A model uma lulik constructed by one of the Grade 12 student cohorts at Mau-Kruma School. Source: school staff member, 2020.

\footnotetext{
${ }^{64}$ Amo Deonildo's work between Catholicism and Ermera's indigenous belief system was exemplified by the laying of a foundation stone for a school in Ponilala in June 2019, which was attended by a visiting Australian school group, who subsequently told me of the trip. Amo Deonildo spoke a prayer at the opening ceremony, and was also present when local residents sacrificed a pig and to be buried under the foundations of the new building. His presence appears to represent an acceptance and acknowledgement of local, pre-Catholic epistemology and ontology.
} 
As mentioned in Chapter Four, 'Timorpratika' is another move to link student learning more fully with what students see around them. (Gabrielson, 2018). Finally, as described in Chapter Five, a government programme incorporating food and agriculture into student learning through the establishment of school gardents is underway at pre-secondary level, and may be extended to senior secondary level in the future. These efforts to link student learning more strongly to their surroundings, everyday realities and cultural heritage are therefore observable at both local and national level.

\section{CONCLUSION}

Secondary school students in Ermera subdistrict overwhelmingly want to go to university and find waged employment in a fairly narrow range of professions, and the primary purpose of the school system appears to be to encourage students to go to university. Classroom learning is overwhelmingly geared towards students sitting the National Examinationss. Given the emphasis on rote learning, with students overwhelmingly learning by copying lesson material from the board into their notebooks, another covert role of the senior secondary education system appears to simply be to keep students busy, as it was in Indonesian times.

What is needed is a more diverse approach to education which is based on local contexts and needs, meeting the priorities and reflecting the realities of local communities. This could be one where agriculture is included as a learning topic, and where practical skills are emphasised alongside basic intellectual competencies. There are already various efforts to better connect learning with students' everyday lives and with local culture, both at government level and local level. My interviews show that at least some students have already gained valuable interpersonal skills in recent years and are strongly socially-minded, and are willing and ready to make the most of the educational opportunities available to them. 
At present, schools and communities Ermera subdistrict have both the motivation and, particularly for the private Imacon School, a degree of freedom to pursue their own educational development goals, such as establishing some resources for students to learn English language and computing skills. However, their resources are financially limited and it is vital that they are supported in these initiatives, so that students can gain the kind of intellectual and practical skills which will equip them with the means to live comfortably in the future. 


\section{Chapter 8: Conclusion}

This thesis investigates the relationship between education and livelihoods in a coffeegrowing region of Timor-Leste, which sits between the urban-rural divide. It focuses on the plans and aspirations which teenagers are developing as they look ahead to their future lives, and whether the education that they are receiving is appropriate for their future goals. I observed, recorded and analysed the experiences and future goals of secondary school students aged sixteen and upwards, along with the views of their parents, teachers, school directors and of other professionals. By focusing on the local experiences of students and their families, my approach turns away from the top-down nature of existing studies, which tend to prioritise international and government viewpoints on education over the experiences of its direct participants.

This research involved a total of twenty-two weeks spent in Timor-Leste, including eleven weeks in Ermera subdistrict, where I spent time in three communities: Ermera vila, Ponilala and Mirtutu. I learned some Tetun, a national language, in order to conduct short surveys with 120 Grade 12 students at the two senior secondary schools in Ermera vila, and eleven individual interviews with students aged sixteen to eighteen. I also interviewed nine parents, three teachers, two school directors, a senior education official, a former Prime Minister, and six other professionals working in education or agriculture. I analysed this data with the aid of theoretical concepts drawn from three literatures: education theory, alternative development theory and decolonisation theory.

Most of the 120 students surveyed wanted to continue to university and a fifth wished to attend a post-secondary school course after they graduated from high school. Of the eleven students interviewed, ten wished to attend university and become either a teacher, journalist, nurse or doctor, and one was considering a range of paths, including journalism, police and military service. 
Students grow up in a diverse economy not unlike the one described by Gibson-Graham (2005), in which gift-giving at cultural events, self-employment and reciprocal labour are as much a part of life as more formal waged work. There is certainly a connection between secondary schooling and local livelihoods as some students return to work as teachers at local schools, and there is a need for some doctors, nurses, police and military personnel in the area. However, none of the students interviewed or surveyed indicated that they wanted to work in agriculture, which reflects a general consensus in other interviews, in the media and in academic research that agricultural work is not seen as desirable or even constitutes proper work. It can seem as though all students seek from education is the means to avoid the livelihoods of their parents.

The parents and students interviewed overwhelmingly had a positive view of education. Parents typically saw education as a path to a better life, with university as the desired next step after secondary school. Several parents hoped that education would not only enable their children to find work, but also allow them to contribute to the nation's development. Family finances were a key concern, as many worked hard as farmers to fund their children's education. Students' future success appears to be more than just an individual experience, as obtaining a stable, well-paid position can improve the circumstances and wellbeing of their families.

I sought a sense of what a good life looks like for students and their parents. Some students had more general, non-economic aspirations which related to living near and to helping their family, and some spoke of a wish to support their parents in the future. The leisure activities they enjoyed typically involved friends and family, suggesting that social connectedness is a key part of living a good life. The parents, teachers and community leaders interviewed typically wanted children to be able to receive an education close to home, continue their studies at university, and gain good work in the future. Being able to participate in cultural events is also an important part of life in Ermera subdistrict. 
Much of the secondary schooling in Ermera seems to be aimed at matriculation to university, but research and anecdotal evidence suggest that a university qualification is neither a sure nor a particularly accessible means to obtaining stable and secure work. Most parents in Ermera have little income with which to pay for years of tertiary tuition fees, and students may not complete their study for this reason, along with others. A large youth population and limited formal employment opportunities have resulted in high levels of unemployment, particularly for the younger generation. Agriculture is the carpet of life in Ermera subdistrict, and it is the sector in which many are engaged in informal work. However, in Ermera, eking out a living in agriculture is hard and incomes are low. There is agreement that expansion and innovation within the agriculture sector, along with the tourism and industry sectors, has the potential to create job opportunities and bolster the livelihoods and financial security of ordinary folk.

The interview and survey results suggest that students are pushed into thinking that university - or failing that, some sort of post-school course - is the logical next step after graduating high school. However, the overwhelming desire for students to attend university occurs within a context of high unemployment, political instability, and the imminent, escalating effects of climate change. Some educators and other professionals have pointed to other options, such as overseas work, gaining practical skills which will always be in demand, and even an environmental rehabilitation project which could address both the existential threat of land degradation and high youth unemployment.

It is important to think about what skills would best benefit those students who do not complete a university qualification, or who graduate and yet do not obtain professional work within the limited formal job market. Ensuring that all students graduate from high school with basic literacy, numeracy and communication skills appears at least as important as pushing students to do well at the national examinations in order to secure a place at university. Incorporating agriculture into the education system would be an intrinsically useful reform, given the fact that this is the sector in which many young adults inevitably end up, and where the majority of families earn some or all their money. Under the MoE such a move is currently underway, with school gardens being introduced at primary and pre-secondary level. Further incorporation of agriculture as a learning topic into the pre- 
secondary and secondary school curriculum, perhaps alongside basic business or entrepreneurial skills, as has been done in the Cook Islands, could benefit students and families alike.

In Ermera subdistrict, there have been several successful initiatives by teachers, priests and residents to develop education for their communities. These include the founding of schools in Ermera vila, Ponilala and Mirtutu, and the establishment of a free English course for local students in Ponilala. Some teachers and principals aspire to set up further English, Computing and other resources for young adults living nearby. It is clear that these local educators are committed to providing relevant, quality education to students in order to improve their future prospects.

There are various challenges to student learning in Ermera subdistrict, including student disengagement. This may be due to a disjuncture between students' daily lives and the material they are taught in school, as well as its mode of delivery. Subject material appears to be predominantly Western-oriented, and the focus is on entrance examinations and memorization. However, aspects of traditional culture are apparent within both senior secondary schools, such as model uma lulik constructed by final year cohorts at Mau-Kruma School, and extracurricular activities run at Imacon School. Further moves to incorporate local epistemologies and skills into the current school system, as advocated by Freire (1972), could more greatly legitimise and help to preserve Ermera's unique cultural heritage, as well as to better connect students' daily lives with their educational experience. For example, learning to build houses, make tais cloth, and about ai-moruk, pre-colonial animist beliefs and even black magic alongside the Western sciences would formally acknowledge these skills and epistemologies. This is the kind of place-based education for development described by Overton et. al. (2020), of which there are examples in several neighbouring contexts: in Papua New Guinea, the Cook Islands and Australia.

The breadth and depth of a Masters thesis is limited: I could only focus on a small geographical area, and the scope of my questions was modest. I only conducted surveys with Grade 12 high school students, for example. As a result, this research does not claim to represent the situation and views of all young people in Timor-Leste. However, even this 
limited view sheds some light on the complex relationship between education and development futures in the country.

This research highlights a need to conduct more work on the experiences, views and aspirations of young people in Timor-Leste's education system. It is important to inform future education planning about the apparent mismatch between what happens in the classrooms of the country and what young people need for their future well-being. Topics which could be explored in the future could include teenagers who do not attend school; employment options for young adults; the aspirations and livelihoods of girls and women; and the subsequent employment paths of citizens who return from overseas work.

There is much rhetoric on education, youth and development in the political sphere. At local level, some students and several of their parents connected the pursuit of education with a desire to contribute to the country's development. The government views education as the key to development and young people as the future of the country, while national leader Xanana Gusmão advocates a path towards modernisation. This 'development for modernization' rhetoric appears to be at odds with the needs and values of rural communities in Ermera subdistrict. The parish priest of Ermera vila spoke of the danger that Ermera's strong communities and cultural heritage will be eroded by the individualising, modernising influence of globalization. There are many different development models, including concepts such as buen vivir, which appear more compatible with the livelihood conditions and priorities of teenage students and their families - most of whom live off the land - than do the ideals and narrow economic framing of Western capitalism.

Exploring what students and parents view as a good life is of great benefit to anybody working within education and development in Timor-Leste. Only when we understand what people regard as important in life, and what they aspire to, can we see what sort of education is likely to best meet their needs. What type of education might enable students to achieve the particular type of development that they and their families envisage as the path toward a good life? What are the desired ends of education? At present the answers to these questions are unclear. What is clearer, though, is that conventional, Western-oriented education alone is not appropriate for this context. The current education system is 
generally geared towards entrance into university, rather than toward the kind of work that, or the fields where, high school leavers have the greatest chance of finding a gainful and secure livelihood. Providing the kind of education that equips future generations of teenagers with the necessary skills with which to earn a sufficient income is critical for their ability to gain a good life for themselves and their family.

What is needed is a more diverse approach to education which reflects the priorities and realities of communities. Given the right resources and sufficient autonomy this could become a reality, given educators and local leaders have already been successfully developing education in their communities for years. It is vital that they are supported in these initiatives. Above all, education should be tailored to the needs and desires of those who participate in it, and who stand to benefit the most from it. 


\section{References}

ABC Alice Springs (2018). Bi-lingual school in Yuendumu. 22 October 2018. Retrieved from https://www.facebook.com/watch/?v=1377750185692984

Adebisi, F. I. (2016). Decolonising education in Africa: Implementing the right to education by Re-Appropriating Culture and Indigeneity. NILQ, 67(4), 433-451.

Agostino, A. (2008). Going beyond development monoculture: critical reflections on the MDGs. Development, 51(2), 228-235.

Almeida, P., Martinho, M. and Cabrita, I. (2014). Evaluating the impact of restructuring secondary education in East Timor. Procedia, 141, 665-669.

Araujo, R. (2016). 'Education as a cornerstone for building democratic values' address to the seminar on The role of the educational system and teachers in the national identity building process, celebrating World Teachers' Day, 12 October 2015. Retrieved from http://timor-leste.gov.tl/wp-content/uploads/2016/10/Education-as-a-Cornerstone-forBuilding-Democratic-Values_12.10.2016.pdf

Bailey, R. (2013). Ni-Vanuatu in the recognised seasonal employer scheme: impacts at home and away. Australian National University SSGMN Discussion Paper, 4. Retrieved from http://dpa.bellschool.anu.edu.au/sites/default/files/publications/attachments/201512/SSGM_DP_2013_4_0_0.pdf

Bailey, R. (2019). Ni-Vanuatu 'making business' through seasonal worker programs. Australian National University Department of Pacific Affairs, 13. Retrieved from https://openresearchrepository.anu.edu.au/bitstream/1885/164521/1/dpa_ib2019_13_bail ey.pdf

Balch, O. (2013). Buen vivir: the social philosophy inspiring movements in South America. The Guardian, 4 February 2013. Retrieved from https://www.theguardian.com/sustainable-business/blog/buen-vivir-philosophy-southamerica-eduardo-gudynas

Bassarewan, A. (2005). Literacy Courses from 1974-1975, p. 41, in J. D. S. Guterres (Ed.) (2005), First National Literacy Conference in Timor-Leste: 15th September 2004, Dili, TimorLeste: Oxfam. 
Batterbury, S. P. J., Palmer, L. R., Reuter, T. R., and others (2015). Land access and livelihoods in post-conflict Timor-Leste: no magic bullets. International Journal of the Commons, 9(2), 619-647.

Bebbington, A. J., Hickey, S., \& Mitlin, D. (2008). Can NGOs make a difference? The challenge of development alternatives. London: Zed Books.

Bertram, G. (2018). 'Why does the Cook Islands still need overseas aid?' The Journal of Pacific History, 53(1), 44-63. Retrieved from https://doi.org/10.1080/00223344.2018.1435966

Bourdieu, P. (1983). Forms of capital. In J. G. Richardson (Ed.) Handbook of theory and research for the sciology of education (241-258). Greenwood Press.

bell hooks (1994). Teaching to transgress: Education as the practice of freedom. New York: Routledge.

Bulloch, H. (2014). Contending developments: local notions of development on Siquijor Island, Philippines. Journal of International Development, 26(1), 177-186.

Burns, R. (2017). Education in Timor-Leste: envisioning the future. Journal of International and Comparative Education, 6(1), 33-45.

Cahoone, L. (Ed.) 2003. From Modernism to Postmodernism: An Anthology, 2nd Edition, London: Blackwell Publishing.

Cameron, J., and Gibson-Graham, J. K. (2007). Community enterprises: Imagining and enacting alternatives to capitalism. Social Alternatives, 26(1), 20-25.

Capelo, A. and Cabrita, I. (2015). School organisation and the mobilization of teachers and students in the use of a new general secondary education curriculum in East Timor. New Approaches in Educational Research, 4(2), 133-140.

Carnoy, M. (1974). Education as Cultural Imperialism, New York: David McKay.

Chambers, R. (2007). PRA, PLA and pluralism: Practice and theory (IDS Working Paper 286). Brighton, UK: IDS.

Chambers, R. and Conway, G. R. (1991). Sustainable Rural Livelihoods: Practical Concepts for the 21st Century. Institute of Development Studies DP 296, University of Sussex, Brighton. 
Chant, S. and Sweetman, C. (2012). Fixing women or fixing the world? 'Smart economics', efficiency approaches, and gender equality in development, Gender and Development, 20(3), 517-529.

Chattier, P. (2019). Beyond development impact: gender and care in the Pacific Seasonal Worker Programme. Gender and Development, 27(1), 49-65. Retrieved from https://www-tandfonlinecom.virtual.anu.edu.au/doi/pdf/10.1080/13552074.2019.1570733?needAccess=true

Christie, M. (2015). Australian Indigenous knowledge and the globalising Social Sciences Journal of Glocal Studies, 2, 93-104.

Collins, D. (1977) Paulo Freire: His Life, Works \& Thought. New York: Paulist Press.

Constanza, R., d'Arge, R., de Groot, R. and others (1997). The value of the world's ecosystem services and natural capital. Nature, 387, 253-260. Retrieved from https://doi.org/10.1038/387253a0

Constituent Assembly East Timor 2002, Constitution of the Democratic Assembly of TimorLeste. Retrieved from http://www.gov.east-timor.org/constitution/constitution-Timor-Leste.pdf

Cook Islands Ministry of Education (2011). Enterprise curriculum. Retrieved from http://www.education.gov.ck/wpcontent/uploads/2015/02/ENTERPRISECURRICULUM2011.pdf

Cook Islands Ministry of Education (2014). Cook Islands curriculum. Retrieved from http://www.education.gov.ck/?page_id=265

Cooley, C. H. (1902). Human Nature and the Social Order. New York: Scribner's.

Cowan, M.P. \& Shenton, R.W. (1996) Doctrines of Development, London and New York: Routledge.

Coxon, E. (2020). Introduction: education for 'development' in Oceania, in S. Johansson-Fua, R. Jesson, R. Spratt and E. Coxon (Eds.) Relationality and learning in Oceania: Contextualizing education for development, Leiden and Boston: Loninklijke Brill NV (1-14). Retrieved from https://doi.org/10.1163/9789004425316_001

Coxon, E., Maebuta, J. and Johansson-Fua, S. (2020). Education for development in context: Solomon Islands and Tonga. In Johansson-Fua, S., R. Jesson, R. Spratt and E. Coxon (Eds.) Relationality and learning in Oceania: Contextualizing education for 
development, Leiden and Boston: Koninklijke Brill NV, (17-41). Retrieved from https://doi.org/10.1163/9789004425316_001

Crang, M., and Cook, I. (2007). Doing ethnographies. London, United Kingdom: SAGE.

Cribb, R. (2006). Timor-Leste (East Timor): History, in L. Daniel (Ed.) The Far East and Australasia 2006, United Kingdom: Routledge, Taylor \& Francis Group (735-751)

Cryan, M., Ed. (2012). Community Voices of the Land. Dili: Matadalan ba Rai. Haburas Foundation, UNDP, Trocaire and OXFAM. In Batterbury et. al., Land access and livelihoods in post-conflict Timor-Leste: no magic bullets. International Journal of the Commons, 9(2), 619-647.

Cuestas-Caza, J. (2018). Sumak kawsay is not buen vivir. Alternautas, 5(1), 51-66.

Cupples, J. and Glynn K., (2014). Indigenising and decolonising higher education on Nicaragua's atlantic coast. Singapore Journal of Tropical Geography, 35, 56-71.

Da Silva, A. (2017). Statement at the United Nations 'The Ocean' conference, 5-9 June 2017. Retrieved from

https://sustainabledevelopment.un.org/content/documents/2561311_MECAE_Ocean_Conf erence_Partnership_Dialogue_5.pdf

Datzberger, S. (2018). Why education is not helping the poor. Findings from Uganda, World Development, 110, 124-139.

Davies, C. A. (2008). Reflexive ethnography: a guide to researching selves and others, 2 nd Edition. London: Routledge.

De Almeida, N. C. (2015). The difficult choices of a post-colonial State: Timor-Leste and international dducational aid: a comparative look at educational aid from Portugal and Australia to Timor-Leste. Masters thesis, Victoria University of Wellington.

De Jesus Soares, HE D. (2016). Timor-Leste: a bilingual and multilingual education system. Presentation at 5th International Conference on Language and Education, 20 October 2016. Retrieved from https://lc.mahidol.ac.th/mleconf/2016/Documents/PresentedFiles/Plenary\%20I\%20-\%20D ulce\%20de\%20Jesus\%20Soares.pdf

De la Torre, L. (2020). Storying place: A tok stori about relationalities in Oceanic education and development. Unpublished doctoral thesis, Victoria University of Wellington. 
Dowling, R. (2010). Power, subjectivity, and ethics in qualitative research. In I. Hay (Ed.) Qualitative research methods in human geography, 3rd Edition. Melbourne, Australia: Oxford University Press (26-39).

Drabek, A. G. (1987). Development alternatives: the challenge for NGOs-- an overview of the issues. World Development, 15(Supplement 1), ix-xv.

Dun, O., Klocker, N., and Head, L. (2018). Recognising knowledge transfers in 'unskilled' and 'low-skilled' international migration: insights from Pacific Island seasonal workers in rural Australia. Asia Pacific Viewpoint, 59(3), 276-292. Retrieved from https://onlinelibrary-wiley-com.virtual.anu.edu.au/doi/pdfdirect/10.1111/apv.12198

Escobar, A. (1995). Encountering development: the making and unmaking of the Third World, Princeton: Princeton University Press.

Estrada, V. M. J. (2012). Indigenous Maya knowledge and the possibility of decolonising education in Guatemala. Doctoral thesis, University of Toronto.

Fleming, K. (2015). Diverse education for diverse economies: The relevance of Rural Training Centres in the Solomon Islands. Masters thesis, Victoria University of Wellington.

Fleming, K. and M. Palomino-Schalscha (2016). Re-envisaging education from a diverse economies perspective: The role of rural training centres in the Solomon Islands. Development, Education and Migration in Oceania (DEMO) Working Paper Series No.2. Wellington: Victoria University of Wellington.

FOKUPERS (2018). Concerns raised about altercations to national preschool and primary curriculum. Press Release, 8 February 2018. Retrieved from https://fokupers.org/latest-news/concerns-raised-about-alterations-to-national-curriculum Foucault, M. (1975). Discipline and Punish: The Birth of the Prison. London: Penguin Books. Fox, J. J. (2001). Diversity and differential development in East Timor: potential problems and future possibilities. In H. Hill and J. M. Saldanha, East Timor: Development Challenges for the World's Newest Nation. Institute of Southeast Asian Studies, Canberra: Singapore and Asia Pacific Press (155-173).

Fox, J. J. (2003). Out of the ashes: deconstruction and reconstruction of East Timor. Canberra: Australian National University E Press, 1-27. 
Fox, J. J. (2008). Repaying the debt to Mau Kiak: reflections on Timor's cultural traditions and the obligations of citizenship in an independent East Timor, in D. Mearns with S. Farram (Ed.) Democratic Governance in Timor-Leste: Reconciling the local and the national, Darwin: Charles Darwin University Press (11-128).

Freire, P. (1972). Pedagogy of the oppressed. Harmondsworth, England: Penguin.

Freire, P. (1996) Letters to Cristina: Reflections on My Life and Work. New York: Routledge.

Fry, T. (2014). Timor-Leste: Unlearning in order to be, in E. Kalantidou and T. Fry (Eds.) Design in the Borderlands, Oxon: Routledge (166-195)

Gabrielson, C. (2018). Timorpratika, Science and Mathematics Education in Timor-Leste. Retrieved from https://timorpratika.wordpress.com/

Gamlen, A., Murray, W. E. Overton, J. (2017). Investigating education, migration and development - Moving triangles in the Pacific, New Zealand Geographer, 73(1), 3-14.

Gegeo, D. W. (1998). Indigenous knowledge and empowerment: Rural development examined from within. Contemporary Pacific, 10(2), 289-315.

General Statistics Directorate Timor-Leste (2015). 2015 Timor-Leste population and housing census data sheet. Retrieved from http://www.statistics.gov.tl/wpcontent/uploads/2016/11/Wall-Chart-Poster-Landscape-Final-English-rev.pdf

Gibson, J. (1999). How can women's education aid economic development? The effect on child stunting in Papua New Guinea, Pacific Economic Bulletin, 14(2), 71-80.

Gibson-Graham, J. K. (2005). Surplus possibilities: Postdevelopment and community economies. Singapore Journal of Tropical Geography, 26(1), 4-26.

Gibson-Graham, J. K. and Roelvink, G. (2011). The nitty gritty of creating alternative economies. Social alternatives, 30(1), 29-33.

GMN News (2018). Estudante 3,072 mak pasa asesu UNTL. 28 January 2018. Retrieved from https://gmntv.tl/pt/saude-e-educacao/2018/01/estudante-3-072-mak-pasa-asesu-untl/

GMN News (2020a). NGO plants seedlings in Tasi Tolu to commemorate National Forestry Day. 26:55, 14 February 2020. Retrieved from https://www.youtube.com/watch?v=y-obqkB981M\&t=2663s 
GMN News (2020b). Agreement on plastic project between the RDTL and MercyCorps. 35:15, 14 February 2020. Retrieved from https://www.youtube.com/watch?v=y-obqkB981M\&t=2663s

GMN News (2020c). Special report on unemployment. 21:00, 16 February 2020. Retrieved from https://www.youtube.com/watch?v=7qNXgvQWqsg\&t=1865s

GMN News (2020d). Xanana Gusmão gives an address at a graduate event. 43:30, 21 February 2020. Retrieved from https://www.youtube.com/watch?v=tjnmUpBXIH8

GMN News (2020e). Dr. Daniel Murphy talks about health in Timor-Leste and his clinic having no money 12:50, 22 February 2020. Retrieved from https://www.youtube.com/watch?v=2bTVp0zkbjQ

GMN News (2020f). Local NGO and local authorities hold a tree-planting event in Manleuana. 45:00, 22 February 2020. Retrieved from https://www.youtube.com/watch?v=2bTVp0zkbjQ\&t=895s

GMN News (2020g). Minister of Education Dulce de Jesus speaks at an inauguration in Manufahi. 24:10, 24 February 2020. Retrieved from https://www.youtube.com/watch?v=V6-Y4dVuKO8

GMN News (2020h). The President and Prime Minister take part in the national treeplanting campaign. 3:20, 13 March 2020. Retrieved from https://www.youtube.com/watch?v=Vg5VgHX4xwo\&t=10s

GMN News (2020i). NGO Mary McKillop Today launches a vanilla-growing project to empower farmers in Railaco. 33:20, 13 March 2020. Retrieved from https://www.youtube.com/watch?v=Vg5VgHX4xwo

GMN News (2020j). Students are the future of the nation: parliamentary discussion on plans to evacuate students from China. 27:00, 17 March. Retrieved from https://www.youtube.com/watch?v=_nGSVP3-jf8\&t=1637s

GMN News (2020k). Suku chief Sandra Lobato talks about agriculture in Leorema, Liquica. 19:00, 14 June 2020. Retrieved from https://www.youtube.com/watch?v=a-5S9nmebvE\&t=1725s

GMN News (2020I). Timorese nationals in South Korea and Australia. 19:00, 15 June 2020. Retrieved from https://www.youtube.com/watch?v=TsGR5JxFVkE 
Gramsci, A. (1992) Prison Notebooks. New York: Columbia University Press.

Gruber, L. and Kosack, S. (2014). The tertiary tilt: Education and inequality in the developing World. World Development, 54, 253-272.

The Guardian (2020). Timor-Leste prime minister offers resignation after political coalition collapses. 25 February 2020. Retrieved from https://www.theguardian.com/world/2020/feb/25/timor-leste-prime-minister-offersresignation-after-political-coalition-collapses

Gudynas, E. (2011). Buen Vivir: Today's Tomorrow. Development, 54, 441-447.

Hall, S. (2002). The west and the rest: discourse and power. In S. S. and J. Haggis (Ed.) Development: a cultural studies reader, Oxford: Blackwell (56-64)

Harker, R., Mahar, C., and Wilkes, C. (1990). The basic theoretical position. In R. Harker, C. Mahar, and C. Wilkes (Eds.) An introduction to the work of Pierre Bourdieu. Houndmills: MacMillan Press Ltd.

Hart, G. (2001). Development critiques in the 1990s: culs de sac and promising paths. Progress in Human Geography, 25(4), 649-658.

Harvey, C. and Russell-Mundine, G. (2018). 'Decolonising the curriculum: using graduate qualities to embed Indigenous knowledges at the academic cultural interface'. Teaching in Higher Education,24(6), 789-808. Retrieved from https://www.tandfonline.com/doi/full/10.1080/13562517.2018.1508131

Healy, S. (2009). Economies, Alternative. In R. Kitchin and N. Thrift, International Encyclopedia of Human Geography, Oxford: Elsevier (338-344).

Hill, H. (1978/2002). FRETILIN, the origins, ideologies and strategies of a nationalist movement in East Timor, MA thesis, Melbourne: Monash University Politics Department. Published with a new introduction as Stirrings of Nationalism in East Timor - FRETILN 1974-78, Otford and Dili: Otford Press.

Hill, H. (2005). The contribution of education to development: Some issues for Timor-Leste. Development Bulletin, Volume 68 (October), 103-107.

Hill, H. (2007). How Education both promotes and undermines development in Timor Leste: the problem of the 'hidden curriculum'. In D. Kingsbury and M. Leach (Eds.) East Tmor: Beyond Independence, Melbourne: Monash University Press. 
Hill, H. (2016). Skills for All as Timor-Leste's initial response to Sustainable Development Goal 4. December 2016. Retrieved from https://www.researchgate.net/publication/324531117_Skills_for_All_as_TimorLeste's_initial_response_to_Sustainable_Development_Goal_4

Hill, H. (2017). In transit to the youth dividend. Background Paper on Education and Training for a New Economy for the UNDP.

Hill, H. (not dated). Chapter 5 - Education and human resource development in Timor's socio-economic development. Unpublished document, 1-37.

Howson, K. (2015). Fair trade for whom? The contribution of fair trade to combating trade inequalities faced by East Timorese coffee producers. Masters thesis, Victoria University of Wellington.

Illich, I. (1971). Deschooling Society. New York: Harper \& Row.

Illich, I. (1973) Planned poverty: The end result of technical assistance. In Celebration of Awareness, Harmondsworth, England: Penguin, 129-143.

Inder, B. and Cornwell, K. (2017). Labour Markets and Productivity in Timor-Leste. Research paper series, Monash University. Retrieved at https://drive.google.com/file/d/OByznZLkW5XMKV01WY1lhWTJBU0k/view?ths=true

Inder, B., Lloyd, D., Cornwell, K. and Tilman, Z. (2013). Coffee, poverty and economic development in Timor-Leste. Research report, Retrieved from https://sites.google.com/prod/monash.edu/monashintimor-org/reports-and-publications Inder, B. and Qu, N. (2018). Coffee in Timor-Leste: What do we know? What can we do? Centre for Development Economics and Sustainability, Monash University. Retrieved from https://sites.google.com/prod/monash.edu/monashintimor-org/reports-and-publications

International Monetary Fund (2019). Report for selected countries and subjects. From World Economic Outlook Database, April 2019. Retrieved from https://www.imf.org/external/pubs/ft/weo/2019/01/weodata/weorept.aspx?pr.x=84\&pr.y $=15 \& \mathrm{sy}=2017 \&$ ey $=2024 \& \mathrm{scsm}=1 \& \mathrm{ssd}=1 \&$ sort $=$ country $\& d s=. \& b r=1 \& c=537 \& s=N G D P D, P P P G$ DP,NGDPDPC,PPPPC\&grp $=0 \& a=$

Johansson-Fua, S. (2016). The Oceanic researcher and the search for a space in comparative and international education. The International Education Journal: Compar- 
ative Perspectives, 15(3), 30-41.

Jones, C. (2012). Weaving niche production into Pacific economies: the social, economic and environmental impacts of FIJI Water on local communities. Masters thesis, Victoria University of Wellington.

Jones, I. (2012). Paulo Freire's Philosophy of Education: Origins, Developments, Impacts and Legacies. Introduction. Available at: https://ebookcentral-proquestcom.virtual.anu.edu.au/lib/anu/detail.action?doclD=918766

Jones, G. W. (2001). Social policy issues in East Timor: education and health. Singapore: Institute of Southeast Asian Studies.

Justino, P., Leone, M. and Salardi, P. (2011). Education and conflict recovery: the case of Timor-Leste. World Bank policy research working paper 5774 (July).

Kammen, D. (2001). The trouble with normal: The Indonesian military, paramilitaries, and the final solution in East Timor. In B. Anderson (Ed.) Violence and the state in Suharto's Indonesia, Ithaca New York: Cornell Southeast Asia Program Publications (156-188).

Kammen, D. (2012). Timor-Leste: Food Security and Profits. Regional Outlook, 27-29, 181. Retrieved from https://search-proquest-com.virtual.anu.edu.au/docview/1473876032 ?accountid=8330

Kirylo, J. D. (2011). Paulo Freire: the Man from Recife. New York: Peter Lang Publishing,.

Kitchin, R., and Tate, N. J. (2000). Conducting research in human geography: Theory, methodology and practice. Harlow, ND: Prentice Hall. Retrieved from https://books.google.co.nz/books?id=vZZEAgAAQBAJ\&pg=PT21\&source=gbs_toc_r\&cad=3\# $v=$ onepage $\& q \& f=f a l s e$

Knutsson, B. and Lindberg, J. (2012). Education, development and the imaginary global consensus: Reframing educational planning dilemmas in the South, Third World Quarterly, 33(5), 807-824.

Knutsson, P. (2006). The sustainable livelihoods approach: A framework for knowledge integration assessment. Human Ecology Review, 13(1), 90-99. Retrieved from https://www.humanecologyreview.org/pastissues/her131/knutsson.pdf

Lao Hamutuk (2020). Timor-Leste petroleum fund. Retrieved from https://laohamutuk.org/Oil/PetFund/05PFIndex.htm 
Lee N. (2008). Getting kids to school in Yuendumu. ABC Alice Springs, 8 April 2008. Retrieved from http://www.abc.net.au/local/stories/2008/03/07/2183666.htm

Lemos, E. (2016). Permaculture/Agroecology system in Timor-Leste National School Curriculum for Basic Education. Retrieved from http://www.fao.org/family-farming/detail/en/c/425624/

Lucas, M., Cabrita, I., and Ferreira, A. (2015). Pathways to change: improving the quality of education in Timor-Leste. Procedia, 186, 732-738.

Martins, F. D. J. (2008). History of Padre Hilário Madeira Pre-secondary school in Ponilala, and proposal for additional funding. 18 March. Tetun: RDTL, Departamentu De Edução Cultura, Juventudes e Desporto. Tetun title: Escola Pre-secondário Pe. Hilário Madeira Ponilala, Filial na Escola Pre-secondario Católica Imaculada Conceição Ermera: Historia.

Masuda, K. and Yamauchi, C. (2018). How does female education reduce adolescent pregnancy and improve child health? Evidence from Uganda's universal primary education for fully treated cohorts. Journal of Development Studies. Retrieved from https://www.tandfonline.com/doi/full/10.1080/00220388.2018.1546844

McCowan, T. and Unterhalter, E. (Eds.) (2015). Education and international development: An introduction. London: Bloomsbury Academic.

McGrath, S. (2010). Education and development: 30 years of continuity and change. International Journal of Education Development, 30(6) 537-543. Retrieved from https://www-sciencedirectcom.helicon.vuw.ac.nz/science/article/pii/S0738059310000611?via\%3Dihub

McGrath, S. (2016). Education and the post-2015 development agenda, Chapter 29 in S. McGrath and Q. Gu (Eds.) Routledge handbook of international education and development. London \& New York: Routledge (401-415). Retrieved from https://ebookcentral-proquestcom.helicon.vuw.ac.nz/lib/vuw/reader.action?doclD=3570036\&ppg=22

McGrath, S. (2018). Education and development. London \& New York: Routledge.

McLennan, J. (2012). An alternative model for development? Promise and politics in the projecthonduras network. Doctoral thesis, Massey University. Retrieved from https://mro.massey.ac.nz/bitstream/handle/10179/3284/02_whole.pdf 
Mertens, D. M. (2005). Transformative Paradigm. In S. Mathison (Ed.) Encyclopedia of Evaluation, Thousand Oaks: Sage (423-424).

Mezirow, J. (2000). Learning as transformation: Critical perspectives on a theory in progress. San Francisco: Jossey Bass.

Millo, Y. and Barnett, J. (2003). Educational development in East Timor, Working Paper No.1, Parkville, Melbourne: University of Melbourne School of Development Studies.

Musitha, M. E. and Mafukata, M. A. (2018). Crisis of decolonising education: Curriculum implementation in Limpopo Province of South Africa. Africa's Public Service Delivery and Performance Review 6(1), 1-8.

Murchison, J. (2010). Ethnography essentials: Designing, conducting, and presenting your research. San Francisco: Jossey-Bass.

Myat Thu, P. and Da Silva, I. (2013). The Australian Seasonal Workers Program: TimorLeste's case. Australian National University College of Asia and the Pacific. Retrieved from http://dpa.bellschool.anu.edu.au/sites/default/files/publications/attachments/201512/SSGM_IB_2013_13_Proof_3_0.pdf

O'Leary, Z. (2010). The Essential Guide to Doing Your Research Project. London, United Kingdom: SAGE.

Overton, J., Stupples, P., Murray, W. E., Gamlen, A., and Palomino-Schalscha, M. (2020). Learning Journeys: Five Paradigms of Education for Development. Asia Pacific Viewpoint (in press), 1-28.

Oxfam Timor-Leste (2020). Agriculture Assessment. Retrieved from https://cng-cdn.oxfam.org/asia.oxfam.org/s3fspublic/file_attachments/Agriculture\%20Assessment-Oxfam\%200221\%20(1).pdf

Palmer, L., Barnes, S. and Kakuma, R. (2017). Opening the paths to healing: developing an integrated approach to health in Timor Leste. Third World Thematics: A TWQ Journal, 2(2-3), 248-262. Retrieved from https://www.tandfonline.com/doi/full/10.1080/23802014.2017.1336423

PBS (2003). Wide Angle Time for School Series: Interview with Amartya Sen. 4 September 2003. Retrieved from https://www.pbs.org/wnet/wideangle/interactives-extras/interviews/time-for-schoolinterview-amartya-sen/1477/ 
Peake, G. (2012). Beloved Land. Melbourne Australia: Scribe Publications.

Pieterse, J. N. (2010). Development theory: Deconstructions/reconstructions. London: Sage Publications Ltd.

Porter, D. and Craig, D. (1997). Framing participation: development projects, professionals, and organisations. Development in Practice, 7(3), 229-236.

Presidensia da Republika (PR). (2016). H.E. President Taur Matan Ruak holds dialogue with the communities of the villages of Licapat and Limeia sorin balu. Press release, 1 June 2016. Retrieved from https://presidenciarepublica.tl/2016/06/5109-2/?lang=en

Provo, A., Atwood, S. Sullivan, E. B. and Mbuya, N. (2017). Malnutrition in Timor-Leste: A review of the burden, drivers and potential response. World Bank working paper. Retrieved from http://documents.worldbank.org/curated/en/666231491492248496/pdf/114087-WPPUBLIC-EAPEC-176-p-MalnutritioninTimorLeste.pdf

Quefi, P. (2015). What are significant developments of technical and vocational education and training (TVET) in Timor-Leste? A new political economy. Directed research, Waikato University.

Quinn, M. (2013) Talking to learn in Timorese classrooms. Language, Culture and Curriculum, 26(2), 179-196.

Radcliffe, S. A. (2012). Development for a postneoliberal era? Sumak kawsay, living well and the limits to decolonisation in Ecuador. Geoforum, 43, 240-249.

Rahnema, M. with Bawtree, V. (Eds.) (1997). The Post-Development Reader, London and New Jersey: Zed Books.

Ranta, E. M. (2016). Buen vivir governance in Bolivia: chimera or unattainable utopia? Third World Quarterly, 38(7), 1603-1618.

Reimer, Everett (1971), School is Dead: An Essay on Alternatives in Education. Harmondsworth, UK: Penguin Education Specials.

Republika Demokratika Timor-Leste (RDTL) Ministry of State Administration (2015). Map showing subdistricts of Ermera. Retrieved from https://web.archive.org/web/20160321173715/http://www.estatal.gov.tl/pt/municipio-deermera/ 
Republika Demokratika Timor-Leste (RDTL) (2016a). Expansion of Secondary TechnicalVocational Education in Timor-Leste. Press release, 23 September 2016. Retrieved from http://timor-leste.gov.tl/?p=16206\&n=1\&lang=en

Republika Demokratika Timor-Leste (RDTL) (2016b). Population distribution by administrative area - volume 2 (aldeia populations). Excel spreadsheet. Retrieved from General Directorate of Statistics Timor-Leste website:

http://www.statistics.gov.tl/category/publications/census-publications/

Republika Demokratika Timor-Leste (RDTL) (2017). Study outlines benefits of learning through mother tongues. Press release, 12 January 2017. Retrieved from http://timor-leste.gov.tl/?p=17110\&n=1\&lang=en

Republika Demokratika Timor-Leste (RDTL) (2019). Launch of HATUTAN education and nutrition programme. Press release, 11 June 2019. Retrieved from http://timor-leste.gov.tl/?p=22566\&lang=en\&n=1

Republika Demokratika Timor-Leste (RDTL) (u. p. d.) About Timor-Leste. Retrieved from http://timor-leste.gov.tl/?p=547\&lang=en

Rose, M. (2019). Science of Life Systems: learning English and looking outward in TimorLeste. Australian National University DevPolicy Blog, 19 December. Retrieved from https://devpolicy.org/science-of-life-systems-learning-english-and-looking-outward-intimor-leste-20191209/

Saïd, E. (2003). Orientalism. London: Penguin Books.

Santos, B. de Sousa (2004). The World Social Forum: Toward a counter-hegemonic globalisation (Part I). In J. Sen, A. Anad, A. Escobar, \& P. Waterman (Eds.) World Social Forum: challenging empires, New Delhi, India: The Viveka Foundation (235-45).

Sanderson, G. (2001). Policy Options for the development of Technical and Vocational Education and Training in East Timor. Capacity Building Programme for East Timor, Dili: AusAID.

Sen, Amartya (1999), Development as Freedom. Oxford University Press, Oxford.

Shor, I. (1992). Empowering education: Critical teaching for social change. Chicago: Chicago University Press. 
Scheyvens, R., Nowak, B., and Scheyvens, H. (2003). Ethical issues. In D. Storey and R. Scheyvens (Eds.) Development fieldwork, London, United Kingdom: SAGE (140-166).

Smith, L. (2019). Timor Leste berry pickers flavour of the month in Tasmania. ABC Rural News, 28 March 2019. Retrieved from

https://www.abc.net.au/news/rural/2019-03-28/timor-leste-seasonal-workers-intasmania/10679304

Smith, L. T. (2012). Decolonising methodologies: research and indigenous peoples, 2nd Edition. London and New York: Zed.

Soares, B. B. (2015). Transnationalism and Development: The Impact of Remittances to Timor-Leste. Masters Thesis, Victoria University of Wellington.

Spivak, G. C. (1988). Introduction: subaltern studies. Deconstructing historiography. In R. Guha and G. C. Spivak (Eds.) Selected subaltern studies, New York, NY: Oxford University Press (3-32).

Stanley M. (2016). Tongan government hopes to increase number of workers on Australian seasonal worker programme. ABC News, 5 September 2016. Retrieved from https://search-proquest-com.virtual.anu.edu.au/docview/1816599017?pqorigsite=summon

Summers, L. (1992). Investing in all the people. Presented at the Annual General Meeting of the World Bank, Washington DC.

Sylvester, C. (1999). Development studies and postcolonial studies: disparate tales of the 'Third World.' Third World Quarterly, 20(4), 703-721.

Tikly, L. (2004). Education and the new imperialism. Comparative Education, 40(2), 173-198.

Tilley, L. and Woodthorpe, K. (2011). Is it the end for anonymity as we know it? A critical examination of the ethical principle of anonymity in the context of 21st century demands on the qualitative researcher. Qualitative Research, 11(2), 197-212.

UNDP (2002). East Timor Human Development Report 2002: The Way Ahead. New York: Author.

UNDP (2020). The Sustainable Development Goals. Retrieved from https://www.undp.org/content/undp/en/home/sustainable-development-goals.html 
UNICEF. (2004). The state of the world's children 2004: Girls, education and development. New York, NY: Author.

UNICEF. (2011). State of the world's children 2011: Adolescence, an age of opportunity. New York, NY: Author.

United Nations Department of Field Support (2011). Map of Timor-Leste. Cartographic Section. Retrieved from https://www.un.org/Depts/Cartographic/map/profile/timor.pdf

Vulliamy, G. (1981). Combining a constructive rural orientation with academic quality: high school outstations in Papua New Guinea. International Journal of Educational Development $1(2), 1-19$.

Walker, M., McLean, M., Dison, A. and Peppin-Vaughan, R. (2009). South African universities and human development: towards a theorisation and operationalisation of professional capabilities for poverty reduction. International Journal of Educational Development, 29(6), 565-572.

Wallenborn, M. (2009) Skills development for poverty reduction (SDPR): the case of Tajikistan. International Journal of Educational Development, 29(6), 550-557.

Watson, K. (1988) Forty years of education and development: from optimism to uncertainty. Educational Review, 40(2), 137-174.

Wechman, R. J. (2000). Dictionary of economics and business: $A$ thousand key terms and people. Chanpaign: Stipes Publishing L.L.C.

Williams, R., Bacon, S., Ferreira, A., and Erskine, W. (2018). An Approach to Characterise Agricultural Livelihoods and Livelihood Zones Using National Census Data in Timor-Leste. Experimental Agriculture, 54(6), 857-873.

Wilson, P. A. (1996). Empowerment: Community economic development from the inside out. Urban Studies, 33(4), 61-631.

Wolcott, H. F. (2008). Ethnography: a way of seeing. Oxford: Altamira Press.

Woodward, K., Dixon, D. P., and Jones III, J. P. (2009). Poststructuralism/Poststructuralist Geographies. In R. Kitchin \& N. Thrift (Eds.) International encyclopedia of human geography, Oxford, United Kingdom: Elsevier (396-407). 
World Bank (2013). Building Evidence, Shaping Policy: Findings of the 2012 Education Survey no. 83766. Dili, Timor-Leste: World Bank Office. 


\title{
Appendix 1: Tetun chapter summaries
}

\section{PREFÁSIU}

\author{
Have you ever seen the rain? \\ Ita-boot haree tiha ona udan? - kanta Ingles
}

Bainhira hau halo peskiza iha postu administrativu Ermera hau iha memória murak ida. Memória nee mosu iha lokraik ida, bainhira hau ho estudante ruma lao husi suku Ponilala ba Ermera vila.

Tinan 2019 fulan Julhu mestre Egidio konvida hau ba kursu Ingles ida iha Ponilala, no depois fulan Julhu ho Agostu ami hanorin hamutuk iha kursu. Tempu nee, bainhira lisaun remata lokraik foin-sa'e ruma bainbain hamaluk hau fila ba Ermera vila.

Lokraik ida sira hatete katak sira-nia hobi ida maka kanta. 'Biin hatene kantadór Rod Stewart? Nia kapás!' Estudante ida hahuu kanta múzika nee, Ita-boot haree tiha ona udan? no estudante seluk hotu mos hahuu kanta. Sira hatete katak uluk malae ida mai kursu Ingles no hanorin kanta Ingles ba estudante iha-ne'eba.

Múzika nee hanesan kona ba: udan-anin ida mosu, no udan monu hela. Múzika nia signifikadu maka: maski udan todan no malirin, maibee liu udan-anin sorin iha loro-matan. Bainhira hau rona múzika nee hau hanoin estudante nia entuziasmu no optimismu neebe ba eskola iha postu administrativu Ermera. Maske estudante ho sira-nia familia hasoru dezafiu barak en relasiaun a 'bein estár', saude, oportunidade edukasaun no serbisu, no dala barak moris laos fasil, maibe sira kontinua hamnasa no sira haree ba oin. Mentalidade nee hanesan haree iha udan sorin atu haree loro-matan, no nee hanesan inspirasaun ba profissional no peskizador sira neebe serbisu iha area dezenvolvimentu. 


\section{KAPÍTULU IDA: INTRODUSAUN}

Iha diskusaun konaba edukasaun iha sosidade nia nivel hotu-hotu iha sosiedade. Jeralmente governu no akademiku sira konkorda katak edukasaun maka importante ba dezenvolvimentu no bein estár.

Ita bele buka oportunidade edukasional atu hetan serbisu (ne'ebe sira hakarak), atu sai di'ak liu ita nia moris, no karik mos atu dezenvolve pessoalmente (dezenvolve iha nivel pessoal).

Edukasaun bele fasilita ita atu bele partisipa iha sosiedade, no mos iha ekonomia mundial. Iha era globalizasaun nee, abilidade nee sai importante ba beibeik. Tanba ne'e, agora edukasaun mak konsidera direitu humanu ida. Edukasaun mos bele foo dalan husi pobreza ba hetan moris diak no nunee edukasaun bele oferese esperansa. Edukasaun mos bele fo matenek ('skill') liu tan atu hetan serbisu, no mos fo liberdade, mentál, no etendimentu diak liu kona ba mundu ba ita, atu fasilita ema atu realiza mudansa positivu iha sira-nia sosiedade. Nunee edukasaun fo benefisiu ba individual no mos ba sira-nia komunidade.

Mais, so edukasaun iha benefísiu sira-nee ba ema ho komunidade se sira-nia sistema edukasaun maka natoon kontestu sosiál. Se sistema edukasaun ida laos kompativel ho fatin ida nia ekonomia no kultura, improvavel loos katak sistema hirak bele krea rezultadu positivu sira-nee. Peskizadór barak (hanesan Freire, Vulliamy, Fleming, Hill, Coxon) hatete katak edukasaun tenki natoon kommunidade espesífiku nia prioridade no nesesidade.

Liuliu iha area Pasífiku, peskizadór (Villiamy, Coxon, Fleming, Hill) afirma katak nasaun poscolonial barak sei iha sistema edukasaun osidental husi colonizador anterior, no sistema refere karik bele hanesan inadequadu, liuliu ba komunidade rural (neebe por exemplu barak liu mak serbisu nuudar kantor). Sistema edukasaun osidental nia ojetivu normalmente hanesan atu prepara estudante ba serbisu profesional, no nee karik laos natoon ekonomima lokal, lingua lokal ho kultura lokal estudante ninian, inklui mos oportunidade serbisu typiku iha area lokal. 
Iha tempu nee analisa kona ba dezenvolvimentu nia signifikadu iha kontestu edukasaun laduun iha: tipu edukasaun saida? Tipu dezenvolvimentu saida? Tipu edukasaun saida bele utiliza atu atinji dezenvolvimentu saida diferente iha fatin-fatin atraves ita-nia mundu.

Peskiza ne'e-nia kestaun sentral de peskiza maka:

Relasauna edukasaun sekundariu, tipu saida maka serve liu ba meius de vida no aspirasaun Timor-Leste ninian?

Subkestaun haat hanesan:

1. Iha postu administrativu Ermera, estudante foin sa'e ho sira-nia inan-aman konsidera 'moris diak' saida?

2. Estudante foin sa'e ho sira-nia inan aman hanoin saida kona ba edukasaun sekundariu?

3. Edukasaun sekundariu iha postu administrativu Ermera kontribui oinsa ba meius de vida lokal?

4. Estudante iha eskola sekundaria neebe idade sanulu-resin-neen ho leten hakarak halo saida iha futuru no tipu edukasaun nian saida bele serve diak liu aspirasaun siranee?

Kapítulu Rua kobre literatura akademiku iha area edukasaun, kapital humanu, meius de vida, idea alternativu dezenvolvimentu ninian no teoria kona ba deskonolisa edukasaun.

Kapítulu Tolu kobre metodologia ho metodu, inklui base filozofiku, pozisaun hakerek-na'in, no kestaun sentral ne'ebe mosu durante prosesu peskiza, inklui mos konsiderasaun etika.

Kapítulu Haat sei foo linha jeral Timor-Leste nian, inklui sistema edukasaun ho ekonomia, no konsidera edukasaun ho meius de vida nia kompleksu iha nasaun refere.

Kapítulu Lima hanesan kapitulu rezultadu premeiru, neebe kobre rezultadu relasiona moris komunidade iha postu administrativu Ermera. Kapítulu nee inklui impulsiona entre 
komunidade tolu ho peskizadora pasa tempu; lia nia signifikadu ba meius de vida ho edukasaun; ho impresaun tentativa 'moris diak' bazeia resultadu hirak.

Kapítulu Seis kobre estudante nia aspirasaun iha kontestu realidade ekonomiku iha Ermera no iha rai luan liu, ekonomia lokal nia kompozisaun, inklui agrikultura nia sentralidade iha abitante nia moris neebe depende ba meiu ambiente.

Kapítulu Hitu fo rezultadu survei no intervista ho estudante, no mos kobre forsa ho dezafiu ruma iha eskola nia laran baseia intervista ho estudante, inan-aman, edukador ho ema professionais.

Kapítulu Ualu fo konkluzaun ho lalatak final, no esplika peskiza nia resultadu nia signifikadu ba edukasaun ho serbisu iha rai doben.

\section{KAPÍTULU RUA: TEORIA}

Jeralmente akademiku ho teorizador sira hatete katak edukasaun bele fasilita dezenvolvimentu, nunee, edukasaun maka parte ida iha akordu internasional barak. Kapítulu nee diskuti literatura akademiku kona ba edukasaun iha diskursu dezenvolvimentu, inklui edukasaun nu'udar kapital humanu, no mos edukasaun ho tipu kapital seluk. Kapítulu nee mos kompara Amartya Sen ho Paulo Freire nia teoria. Paulo Freire nia teoria iha influensa makas iha area edukasaun, no inspira modelu radikal edukasaun no dezenvolvimentu nian, no mos inspira teorizador rua, Ivan Illich ho Everett Reimer. Kapítulu mos kobre tipu dezenvolvimentu alternativu neebe parte teoria 'pos-dezenvolvimentu', inklui ideia neebe fokus iha 'bem-estar' no meiu ambiente. Teorizador J. K. Gibson-Graham (2005) formula ona enkuadramentu ida neebe rekonhese katak iha maneira moris diferente no realidade ekonomika iha kapitalismu convensional nia liur. Teorizador nain rua nee suporta tipu edukasaun ba dezenvolvimentu neebe bazeia iha fatin local. Ikus mai, kapítulu sei konsidera literatura kona ba 'decolonising education' neebe korresponde ho teoria posdezenvolvimentu no mos ho teoria dezenvolvimentu alternativu, no konklui katak en geral area akademiku tolu-nee ladauk iha koneksaun ho malu iha peskiza dezenvolvimentu nia 
laran. Ladun iha peskiza neebe esplora tipu edukasaun saida bele kaer tipu dezenvolvimentu saida. Edukasaun nia objetivu tenki hanesan saida? Oinsa tipu edukasaun ida bele kaer atu atinji estratejia dezenvolvimentu espesifiku? Agora iha peskiza rua deit (Overton et. al. 2020, Fleming 2015) neebe halo ligasaun entre area akademiku tolu-nee atu halo peskiza dezenvolvimentu iha Oceania. Peskiza nee tuir peskizador nain tolu nee nia ezemplu atu esplora hanoin kona ba edukasaun no aspirasaun ba futuru iha area semi-rural iha TimorLeste.

\section{KAPÍTULU UALU: KONKLUSAUN}

Kapítulu Ualu fo konkluzaun ho lalatak final, no esplika peskiza nia resultadu nia signifikadu ba edukasaun ho serbisu iha rai doben.

Monografia nee investiga ligasaun entre edukasaun ho vida moris iha area iha Timor-Leste katak tuur iha area urbanu ho rural nia leet. Monografia nia fokus maka foin sa'e nia planu no mehi iha futuru, no espesifiku, se estudante nia edukasaun akordu ho aspirasaun hirak nee. Hau observa, rekorda ho analisa tiha ona estudante sekundariu nia esperiensia ho finalidade ho idade sanulu-resin-neen ho leten, no mos halo intervista ho inan-aman, mestre, diretor eskola ho professional sira seluk. Peskiza nee nia abordajen maka diferente husi peskiza sira seluk neebe normalmente fo prioridade ba opinaun estatal ho internasional tanba ninia fokus maka estudante ho sira-nia familia nia hanoin ho esperiensia.

Hau hanesan peskizadora halo peskiza iha Timor-Leset durante semana 22 nia laran, inklui mos pasa tempu durante semana sanulu 11 iha postu administrativu Ermera. Peskiza nee involve hala'o survei ho estudante iha klasse tiga nain 120 iha Ermera vila, no intervista 21 ho profesional sira-seluk. Hau analisa dadus nee ho teoria tipu tolu: teoria edukasaun, teoria dezenvolvimentu alternativu ('alternative development'), no teoria deskonolizasaun ('decolonisation theory').

Husi estudante klasse tiga nain 120, barak hakarak ba universidade. Um quinto (20\%) hakarak tuir kursus depois de hasai husi eskola sekundariu. Relasiona estudante nain 11 
neebe tuir intervista, sanulu mos hakarak ba universidade no sai mestre, jornalista, enfermeira ka doutor.

Estudante sai boot iha ekonomia diversa neebe Gibson-Graham (2005) mensiona iha sira-nia peskiza. Ekonomia la'os ekonomia kapitalista deit, tanba iha atividade lia, iha atividade ekonomika non-formal, ho mos trabalho reciproko no seluk tan. Iha konesaun entre eskola sekundariu ho okupasaun lokal tanba iha doutor, enfermeira, polisia, pesoal militar no seluk tan, no estudante ruma mos fila ba Ermera vila atu serbisu hanesan mestre. Maibee estudante hotu lakohi serbisu iha setor agrikultur, no nee akordu ho resultadu intervista ho peskiza seluk katak ema barak konsidera serbisu toos laduun diak, ka hanoin serbisu toos nee laos serbisu (ezemplu nee maka lider FONGIL nia opiniaun). Estudante karik seguir edukasaun atu hadook an husi inan-aman nia vida moris.

Estudante ho inan-aman neebe tuir intervista hanoin edukasaun diak. Inan-aman barak haree edukasaun hanesan dalan ba moris diak, no haree universidade hanesan etapa tuir mai depois de eskola sekundariu. Inan-aman ruma espera katak edukasaun bele fasilita sirania oan atu hetan serbisu, no mos kontribua ba nasaun nia dezenvolvimentu. Dala barak, estudante nia susesu iha futuru laos individual tanba hetan kampu trabalhu diak ida bele halo sai diak liu membru familia seluk nia moris ('bem-estar').

Dala barak, ensino sekundariu iha Ermera nia objetivu maka fasilita estudante liu exame nasional ho tama ona ba universidade. Maibee, peskiza seluk ho resultatu intervista sujere katak diploma husi universidade laos garante katak foin sa'e hetan serbisu iha futuru. Iha Timor-Leste iha juventude barak neebe buka hela serbisu maibee la hetan. Setor Agrikultur, no mos setor turismu ho industria iha potensial atu krea kampu trabalhu no nunee halo sai diak liu ema kiik nia vida moris ho seguransa finanseira. Survei ho intervista nia resultadu sujere katak eskola sekundariu (hanesan karik edukador) dudu estudante atu hanoin katak universidade iha dalan etapa oin mai depois de remata eskola. Maibee, rai nia kontestu hanesan dezempregu aas, inserteza politika, no mudansa klimatika nia ameasa. Edukador ho profesional ruma sujere dalan seluk, por ezemplu serbisu iha rai liur, hetan matenek pratiku neebe sosiadade tomak presiza, no mos projetu ambiental neebe bele halo reabilitasaun ambiental no mos krea kampu serbisu ba juventude. 
Iha nivel governmental iha diskusaun barak kona ba dezenvolvimentu. Estudante no inanaman ruma fo liga entre edukasaun ho estudante nia abilidade atu kontribui ba rai nia dezenvolvimentu. Governu aree edukasaun hanesan 'xave ba dezenvolvimentu'. Lider nasional Kayrala Xanana Gusmao advoka dalan modernizasaun. Maibee, retorika estatal nee karik la akorda ho komunidade rural nia nesesidade no valor sira. Iha padre ida husi postu administrativu Ermera hanoin, iha perigu katak globalisasaun (inklui mos individualismu no modernismu) bele afeta komunidade sira-nia forsa no kultura. Iha dalan dezenvolvimentu barak, no nee inklui 'buen vivir', no tipu dezenvolvimentu alternativu karik apar diak liu ho estudante no familia nia vida moris i prioridade. Nee tanba familia barak nia vida moris depende ba meiu-ambiente, no estudante ho inan-aman barak preokupa ho malu nia 'bemestar'. Kapitalismu osidental nia visaun ekonomika i valores karik laos apropriadu iha nivel lokal.

Estudante ho inan-aman hanoin 'good life' (boa vida) maka saida? Se ita hatene ema nia prioridade no ema nia aspirasaun, ita bele determina tipu edukasaun saida hanesan diak liu. Modelu edukasaun saida bele fasilita estudante atu atinji tipu dezenvolvimentu neebe sira ho sira-nia familia haree hanesan dalan ba moris diak? Edukasaun nia objetivu maka saida? Agora resposta sira ba kestaun sira-nee laos klaru. Maibee, klaru karak edukasaun osidental laduun servi kontestu postu administrativu Ermera. Krea tipu edukasaun neebe fo foin sa'e ho matenek (mental ho pratikal) neebe bele ajuda sira atu hetan kampu trabalhu seguru importante - tipu edukasaun ida neebe bele realiza estudante nia presiza no mehi, nee importante tebes ba sira-nia abilidade atu hetan moris diak ba sira-nia an ho sira-nia familia. 


\title{
Appendix 2: Survey and interview forms
}

\section{SURVEY FORMS}

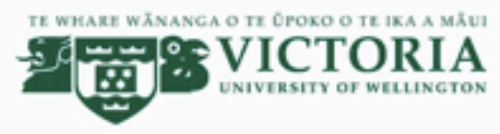

\section{Ensinu sekundáriu no servisu iha distritu Ermera, Timor- Lorosae}

\author{
Peskizadora: Anna Mitchell, Eskola Siénsia, Universidade Victoria \\ Wellington, Nova Zelandia
}

\section{KARTA INFORMASAUN BA PARTISIPANTE (SURVEI)}

Hau konvida ita atu partisipa iha peskiza ida ne'e. Favor ida lee informasaun iha karta ne'e antes hili hola parte ka lae. Se ita hola parte ona, obrigada barak. Se ita hola parte, hau sei agradese nafatin ita ba ita-nia konsiderasaun.

Se mak hau?

Hau nia naran Anna Mitchell no hau estudante mestradu. Hau halo hela Estudiu Dezenvolvimentu iha Universidade Victoria Wellington. Hau halo peskiza ba hau nia mestradu no peskiza ne'e mak kontribui ba hau-nia thesis.

Saida mak projetu ne'e nia objectivu?

Programa ida ne'e atu hatene informasaun konaba ensinu sekundariu no serbisu iha distritu Ermera. Hau sei husu ba foin sae sira husi 16 to'o $18+$ ne'ebe ba eskola iha Ermera vila. Hau hakarak hatene sira-nia hanoin konaba sira-nia edukasaun, no sira-nia aspirasaun iha futuru. Peskiza ida ne'e aprovado husi Komisaun Étika iha Universidade Victoria Wellington (ho númeru 000002796).

\section{Oinsa ita bele ajuda?}

Hau konvida ita atu participa iha peskiza ne'e tanba ita iha esperiensia uniku konaba peskiza ida ne'e nia asuntu. Se ita hatan partisipa, hau sei fo survei ida ba ita iha ita-nia eskola.

Pergunta sira iha survei mak konaba ita-nia esperiensia iha edukasaun nivel sekundario, itania planu no aspirasaun ba futuru, no ita-nia inan-aman halo serbisu saida. Survei nia tempu másimu mak minutu 30. La obriga ita tenki hatan ba pergunta sira. Ita mos bele para survei iha kualker tempu no ita la tenke fo razaun ruma.

Ita mos bele kontaktu hau para sai hosi projetu iha kualker tempu antes 30 Septembru 2019. Se ita hili atu sai, hau sei destroi informasaun katak ita fahe tiha ona ho hau ka fo informasaun fila ba ita.

Saida mak ha'u sei halo ba informasaun ne'ebe ita fahe ho hau?

Peskiza ne'e segredu no hau la uza ita-nia naran iha relatoriu ikus nia laran. Karik ita lakohi konfidensialidade, hau bele uza ita-nia naran iha relatoriu ikus nia laran.

Só hau-nia profesor no ajuda nain (ne'ebe sei asina akordu confidensialidade ida) no hau sei lee nota konaba survei. Dokumentasaun konaba survei sei rai didiak to'o 3 Marsu 2023. Iha loron ida-ne'e dokumentasaun sei destroi hotu.

Peskiza ne'e-nia uzu oinsa? 


\section{Ensinu sekundáriu no servisu iha distritu Ermera, Timor-Lorosae}

Peskizadora: Anna Mitchell, Eskola Siénsia, Universidade Victoria Wellington, Nova Zelandia

\section{KONKORDA BA SURVEI}

Karta konkordansia ne'e sei rai didiak durante tinan 5 nia laran.

Peskizadora: Anna Mitchell, Eskola Siénsia, Universidade Victoria Wellington, Nova Zelandia

- Hau lee ona karta konaba informasaun. Peskizadora no ajuda nain esplika ona projetu ne'e. Hau kontenti katak sira hatan ona hau-nia pergunta. Hau hatene katak hau bele husu pergunta liu iha kualker tempu.

- Hau konkorda atu asisti iha survei badak ida.

Hau kompriende katak:

- Hau bele sai husi projetu iha kualker tempu antes 30 Septembru 2019 no informasaun ne'ebe hau fahe tiha ona ho peskizadora sei destroi hotu ka fila fo ba hau.

- Informasaun ne'ebe identifika hau sei destroi hotu iha 3 Marsu 2020

- Informasaun ne'ebe hau fo ba peskizadora sei rai metin. Só peskizadora, ninia profesor no ajuda nain bele haree informasaun ne'e.

- Hau kompriende katak peskizadora sei uza informasaun hosi peskiza iha ninia thesis no mos publikasaun akademiku no konferensia ruma.

\begin{tabular}{|l|l|l|l|}
\hline - & $\begin{array}{l}\text { Relatoriu ka publikasaun futuru sira la inklui hau-nia naran ka informasaun } \\
\text { ruma katak bele identifika hau. }\end{array}$ & Sin & $\begin{array}{l}\text { Lae } \\
0\end{array}$ \\
\hline - & Hau hakarak simu rezumu eskrita ida hosi survei. & Sin & $\begin{array}{c}\text { Lae } \\
0\end{array}$ \\
\hline - & $\begin{array}{l}\text { Hau hakarak simu kopia ida relatoriu peskiza nian no hau hakerek ona hau- } \\
\text { nia email ka numeru WhatsApp ka naran iha Facebook iha kraik. }\end{array}$ & $\begin{array}{l}\text { Lae } \\
0\end{array}$ \\
\hline
\end{tabular}

Partisipante nia asinatura:

Partisipante nia naran:

Data:

Kontaktu: 


\title{
2. INTERVIEW FORMS
}

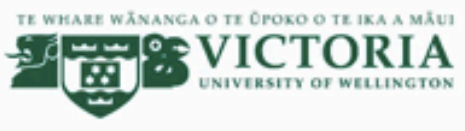

\section{Ensinu sekundáriu no servisu iha distritu Ermera, Timor- Lorosae}

\author{
Peskizadora: Anna Mitchell, Eskola Siénsia, Universidade Victoria \\ Wellington, Nova Zelandia
}

\section{KARTA INFORMASAUN BA PARTISIPANTE}

Hau konvida ita atu partisipa iha peskiza ida ne'e. Favor ida lee informasaun iha karta ne'e antes hili hola parte ka lae. Se ita hola parte ona, obrigada barak. Se ita la hola parte, hau sei agradese nafatin ita ba ita-nia konsiderasaun.

\section{Se mak hau?}

Hau nia naran Anna Mitchell no hau estudante mestradu. Hau halo hela Estudu Dezenvolvimentu iha Universidade Victoria Wellington. Hau halo peskiza ba hau nia mestradu no peskiza ne'e mak kontribui ba hau-nia thesis.

Saida mak projetu ne'e nia objectivu?

Programa ida ne'e atu hatene informasaun konaba ensinu sekundariu no serbisu iha distritu Ermera. Hau sei husu ba foin sae sira husi 16 to'o $18+$ ne'ebe ba eskola iha Ermera vila. Hau hakarak hatene sira-nia hanoin konaba sira-nia edukasaun, no sira-nia aspirasaun iha futuru. Peskiza ida ne'e aprovado husi Komisaun Étika iha Universidade Victoria Wellington (ho númeru 000002796).

\section{Oinsa ita bele ajuda?}

Hau konvida ita atu participa iha peskiza ne'e tanba ita iha esperiensia uniku konaba peskiza ida ne'e nia asuntu. Se ita hatan partisipa, hau no ajuda nain sei husu ita pergunta ruma iha fatin komunidade, eskola ka uma ida. Se ita foin sa'e husi 16 to'o $18+$, pergunta sira mak konaba ita-nia esperiensia iha edukasaun nivel sekundariu no ita-nia planu no aspirasaun iha futuru. Se ita ema boot ida ne'ebe serbisu iha setór edukasaun ka agricultura, pergunta sira mak konaba edukasaun sekundariu no mos konaba halo serbisu. Intrevista nia tempu másimu mak minutu 60 . Se ita hatan, hau sei halo gravasaun-audio no depois hakerek. Ita la presiza hatan pergunta sira. Ita mos bele sai intervista iha kualker tempu no ita la presiza razaun ruma.

Ita mos bele kontaktu hau para sai hosi projetu iha kualker tempu antes 30 Septembru 2019. Se ita hili atu sai, hau sei destroi informasaun katak ita fahe tiha ona ho hau ka fo informasaun fila ba ita.

Saida mak ha'u sei halo ba informasaun ne'ebe ita fahe ho hau?

Peskiza ne'e segredu no hau la uza ita-nia naran iha relatoriu ikus nia laran. Karik ita lakohi konfidensialidade, hau bele uza ita-nia naran iha relatoriu ikus nia laran.

Só hau-nia profesor no ajuda nain (ne'ebe sei asina akordu confidensialidade ida) no hau sei lee nota konaba intervista. Hau sei rai di-diak dokumentasaun konaba intervista to'o 3 Marsu 2023. Tha loron ida-ne'e dokumentasaun sei destroi hotu.

Peskiza ne'e-nia uzu oinsa? 


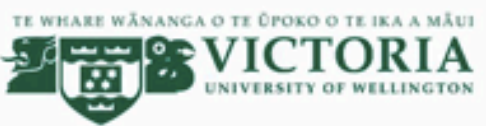

\section{Ensinu sekundáriu no servisu iha distritu Ermera, Timor-Lorosae}

\section{Peskizadora: Anna Mitchell, Eskola Siénsia, Universidade Victoria Wellington, Nova Zelandia}

\section{KONKORDA BA INTERVISTA}

Karta konkordansia ne'e sei rai didiak durante tinan 5 nia laran.

- Hau lee ona karta konaba informasaun. Peskizadora no ajuda nain esplika ona projetu ne'e. Hau kontenti katak sira hatan ona hau-nia pergunta. Hau hatene katak hau bele husu pergunta liu iha kualker tempu.

- Hau konkorda atu gravasaun-audio iha intervista.

Hau kompriende katak:

- Hau bele sai husi projetu iha kualker tempu antes 30 Septembru 2019 no informasaun ne'ebe hau fahe tiha ona ho peskizadora sei destroi hotu ka fila fo ba hau.

- Informasaun ne'ebe identifika hau sei destroi hotu iha 3 Marsu 2020.

- Informasaun ne'ebe hau fo ba peskizadora sei rai metin. Só peskizadora, ninia profesor no ajuda nain bele haree informasaun ne'e.

- Hau kompriende katak peskizadora sei uza informasaun hosi peskiza iha ninia thesis no mos publikasaun akademiku no konferensia ruma.

\begin{tabular}{|l|l|l|l|}
\hline - & $\begin{array}{l}\text { Relatoriu ka publikasaun iha futuru sei la inklui hau-nia naran ka } \\
\text { informasaun ruma ne'ebe identifika hau. }\end{array}$ & Sin & $\begin{array}{l}\text { Lae } \\
0\end{array}$ \\
\hline - & Hau hakarak simu rezumu eskrita ida hosi intervista. & Sin & $\begin{array}{c}\text { Lae } \\
0\end{array}$ \\
\hline - & $\begin{array}{l}\text { Hau hakarak simu kopia relatoriu ikus peskiza nian ida no hau hakerek ona } \\
\text { hau-nia email ka numeru WhatsApp ka naran iha Facebook iha kraik. }\end{array}$ & Sin & $\begin{array}{l}\text { Lae } \\
0\end{array}$ \\
\hline
\end{tabular}

Partisipante nia asinatura:

Partisipante nia naran:

Data:

Kontaktu: 


\section{Appendix 3: Permission letters}

\section{PERMISSION LETTER FROM MINISTRY OF EDUCATION}

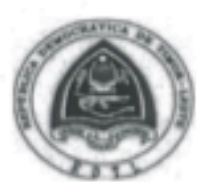

REPÚBLICA DEMOCRÁTICA DE TIMOR-LESTE MINISTÉRIO DA EDUCAÇÃO, JUVENTUDE E DESPORTO

Direçăo Nacional do Ensino Secundírio Geral

Rua de Vila Verde, Telefone: 3339669

Para: 1. Ex.mo Senhor Duarte Bragança,

Diretor de Educação Municipal de Dili;

2. Ex.mo Senhor Carlos Salsinha,

Diretor de Educação Municipal de Ermera

Assunto : Carta de Autorizaç̃o para Pesquisa

No. de Ref. 152/DNESG-MEJD/VI/2019

Dili, 9 de novembro de 2017

Baseado na carta do Director of the Postgraduate Programme in Develoment Studies degree at Victoria University of Wellington-Austrália, sobre a pesquisa nas escolas do Ensino Secundário Geral e serviços administrativos nos municipios de Dili e Ermera, Assim, a Direção Nacdional do Ensino Secundário Geral do Ministério da Educaçalo, Juventude e Desporto informa aos senhores Diretores a fim de autorizar e facilitar a estudante cuja nome :

Nome

: Anna Mitehell

No. ID

: 300464469

Estudo

: Posgraduaçẫo em Geografia e Meio Ambiental

Universidade

: Vitória em Wellington-Austrália

A fim de realizar a sua pesquisa sobre o "Estudo de Caso sobre a Geografia e o Meio Ambiental",

Os nossos melhores cumprimentos e votos de yon bö́r spopperagato.

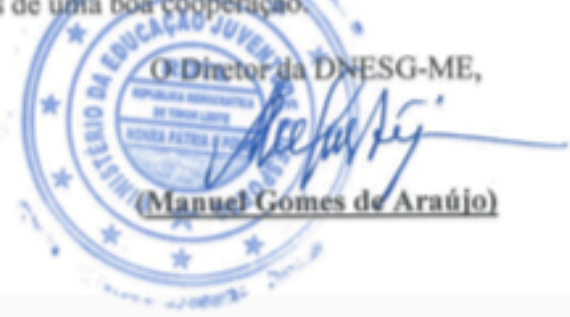


18 June 2019

LETTER OF PERMISSION TO CONDUCT RESEARCH

To Whom It May Concern:

This is to certify that Anna Mitchell may conduct research in Dili and Ermera districts for the thesis component of her Master of Development Studies at the Victoria University of Wellington, New Zealand. She has approval to undertake fieldwork activities between June and September 2019.

She has approval to conduct research on secondary education and livelihoods in Dili and Ermera districts in Timor-Leste. The Ministry has seen written permission from her supervisor, Professor John Overton, who is also the Director of the Postgraduate Programme in Development Studies.

KARTA LISENSA NIAN BA HALO PESKIZA

Ba ema ruma se karik tau matan ho informasaun ne'e:

Surat ida ne'e verifika katak Anna Mitchell bele halo peskiza iha Timor-Leste. Nia agora foti mestradu "Estudu Dezenvolvimentu" iha Universidade Victoria Wellington ('Victoria University of Wellington') iha Nova Zelandia. Nia iha permisaun ba halo peskiza ba fulan Juñu to'o fulan Setembru 2019.

Nia bele halo peskiza konaba ensiñu sekundariu no serbisu iha distritu Dili no distritu Ermera. Ministério Edukasaun haree ona karta liscensa hosi peskadora-nia profesor, Profesor John Overton. Nia mak Diretór Programa Pos-graduasaun ba Estudu Dezenvolvimentu.

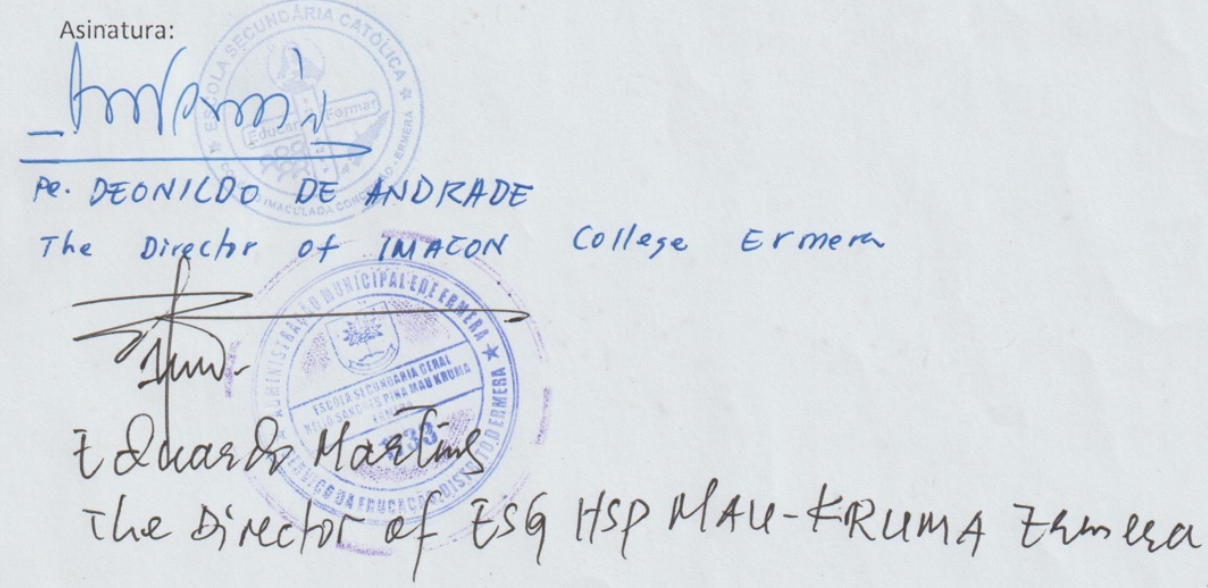




\section{Appendix 4: Survey questionnaire form}

\section{Surat Survei}

Títulu Projeto Peskiza: Edukasaun sekundáriu no servisu iha distritu Ermera, Timor-Lorosae

Peskizadora: Anna Mitchell, Eskola Siénsia, Universidade Victoria Wellington, Nova Zelandia

Survei nia pergunta sira

SURVEI BA FOIN SA'E TINAN 16-18+ NE'EBE HELA BESIK ERMERA VILA

1. Naran

2. Jéneru (feto/mane)

3. Tinan hira

4. Ita hela iha-ne'ebe?

5. Ita moris iha-ne'ebe?

6. Ita tuir klase siénsia sosiál ka siénsia natural?

7. Ita gosta matéria saida iha eskola?

8. Ita hakarak halo saida depois remata eskola sekundariu?

9. Ita halo serbisu saida semana semana? (Ezemplu: serbisu uma)

10. Ita-nia inan-aman halo serbisu saida atu hetan osan? 


\section{Appendix 5: Reference letters for student research assistants}

\section{To Whom It May Concern:}

[RA name] acted as a research assistant for my field research at Public Secondary School, Hélio Sanches Pina Mau-Kruma of Ermera, in Ermera vila, Timor-Leste. [RA name] worked as an English to Tetun translator, gave instructions to the participants and resolved questions from participants during three survey sessions in August and September 2019.

[RA name] has learned about the process of conducting surveys in a school environment and shown that $\mathrm{s} /$ he has excellent communication skills. [RA name] is a knowledgeable, helpful student and her/his assistance greatly improved the success of my research activities.

I would recommend her/him to any future employer.

Anna Mitchell

Masters student in Development Studies

Victoria University of Wellington

\section{Ba Ema Ne'ebé Maka Interese:}

[RA naran] serbisu hanesan assistente peskiza ba ha'u-nia peskiza iha Eskola Sekondaria Publika Hélio Sanches Pina Mau-Kruma Ermera, iha Ermera vila, Timor-Leste. Nia serbisu hanesan tradutor ho Ingles-Tetun, no nia fo instrusaun sira ba partisipante sira no mos resolve perguntas husi partisipante sira durante sessaun survei dala tolu iha Agostu no Setembru 2019.

Agora [RA naran] hatene kona ba prosesu ho halo survei sira iha ambiente eskola no nia hatudu nia kapasidade ekselente iha komunikasaun. Nia matenek tebes no nia sempre prontu atu ajuda ema seluk. Ninia ajuda aumenta ona ha'u-nia peskiza nia susesu.

Ha'u nafatin rekomenda nia ba kualker patraun iha futuru.

Anna Mitchell

Estudante mestradu ne'ebé estuda hela Estudu Dezenvolvimentu

Universidade Victoria iha Wellington 


\section{Appendix 6: Additional material}

\section{THE GOOD LIFE}

One Thursday (11/7/2019) I taught a lesson on 'emotions' and 'happiness' at the free English course. I went through a list of different emotions, getting them to translate them into the Tetun equivalents. I then focused on happiness/sadness, 'Are you happy?', then 'Why are you happy/sad?' Then, on a whim, I asked students, 'What makes you happy?' I wrote a little explanation on the board: 'Happiness can be anything. Anything can make somebody happy. For example, my friend is happy when it rains. The rain makes him happy.'

The students seemed to respond well to this exercise, and they were forthcoming with their answers. I asked them to give a verbal answer in English, and then write it on the blackboard.

Some of their answers are below.

'Playing football $(\mathrm{m})^{65}$.' 'Playing guitar with my friend.' 'Going to church.' 'Listening to music (m). ' 'Practicing English with mana Anna.' Watching TV with my family (m).' 'Hanging out with my girlfriend $(\mathrm{m})$. ' 'Drinking alcohol with my father $(\mathrm{m}) .{ }^{66}$ 'Studying with friends $(\mathrm{m})$. ' 'Going to a party and dancing with my friends $(\mathrm{m})$.'

Other lessons I taught that students seemed to enjoy the most were stories about Australian culture such as the story of the Rainbow Snake, Australian slang words, and learning English songs together, such as 'Three Little Birds' by Bob Marley. I asked them about their own folklore, and in fact one local myth was extremely similar to the Rainbow Snake story.

\footnotetext{
${ }^{65}$ I have marked ' $\mathrm{m}$ ' for responses by male students.

${ }^{66}$ This response was given by a teenager whose English was probably the best of all the students I met. He said this as a joke, and the rest of the students let out a whoop of laughter. I treated this answer like the others and let him write it on the blackboard along with the other answers.
} 
Out of all the lessons, the students seemed the most engaged with the 'happiness lesson'. They seemed to enjoy talking about the topic and being able to share information about themselves. All the students' hobbies involved social contact, particularly with friends and family, and creative and sporting activities.

\section{STUDENTS' WEEKLY CHORES}

Teenagers do a wide range of chores to help their parents at home. The surveys with Grade 12 students revealed that boys and girls did a lot of the same tasks, such as helping their parents in the garden (growing vegetables, weeding, picking coffee), fetching water, cleaning, cooking, and washing dishes and clothes.

Boys were more specific about the work they did in the garden, which included tilling, planting and growing seedlings, watering plants and chopping up firewood. One boy helped by taking his father to work (most likely by motor).

More girls than boys reported washing clothes, washing dishes and cooking, and two reported looking after children, However, eleven boys reported doing at least one of these tasks. It may be that if a family has no or few daughters, boys will step in to do this side of the housework instead (Interview with teenage student, 15/9/2019, Ponilala). More boys than girls reported fetching firewood, and only boys mentioned looking after animals, which was also the case for the student interview participants.

\section{WIDESPREAD USE OF THE INTERNET AND SOCIAL MEDIA}

According to Director Martins, who started teaching in the year 2000 and has worked at Imacon, 20 de Agosto and Mau-Kruma Schools, in the past, before the digital era in TimorLeste, students were hard-working and active in their studies. Now, however, they weren't as hardworking or as engaged in school, which he believed was due to their preoccupation with the digital world. They enjoyed looking at Facebook, surfing the internet and watching porn videos and they also liked going to parties and dancing. In short, many students were now focused on having fun rather than on their schooling, and their study was suffering as a result. Xanana Gusmão, in a speech at a graduation ceremony in Dili, has also decried the 
excessive use of phones among young people and the effect on their education. He urged students to play on their phones less and help their parents more, and focus on their studies, or risk ruining their future (GMN, 2020d).

\section{THE IMPACT OF PORNOGRAPHY ON TEENAGERS' EDUCATION AND FUTURES}

Both Dr Martins and Mr Felix saw a direct causation between young people - presumably boys - watching pornography and teenage girls falling pregnant.

Director Martins observed that the era of globalization had brought with it this phenomenon: teenagers (labarik) were watching pornographic films, liking what they saw, and in their free time when they were allowed to use their phones (as phones are banned during school time at both Imacon and Mau-Kruma Schools), they would go into the forest (kafe huun) ${ }^{67}$ imitate what they saw. Mr Felix also saw these 'free relationships' (casual, premarital sex) as a problem arising from boys watching pornography and reenacting it.

Mr Felix also talked about the consequences for relationships between teenage girls and boys, including early pregnancy. He felt that boys watching pornography, combined with a 'negative' way of thinking, was resulting in them sexualizing their relationships with girls and soliciting them for sex. 'The result is a baby, and then they should be married.'

Mr Felix felt that another contributing problem was young mens' arrogance, which came from immaturity. Boys did not appreciate that marriage was a big responsibilty.

While everybody has their right to marry or continue study, Mr Felix believed that youth who decided to get married at sixteen or seventeen years of age were misguided. He mentioned a prohibition by the Catholic church on early marriage: women should be at least eighteen, and men should be twenty-five or older. Clearly, however, this religious prohibition is not preventing teenage pregnancy.

\footnotetext{
${ }^{67}$ This appears to be both an actual phenomenon and a euphemism: coffee plantations offer relative privacy as compared to homes, which often have many family members sharing a limited number of rooms.
} 
According to Director Martins, while fewer teenage girls drop out of school after falling pregnant as compared to the past, it does still happen. As of September 2019, twenty-nine girls at Mau-Kruma School had dropped out of school for this reason, and this number would likely increase as the exam period and the end of the year approached.

Mr Felix believed that getting pregnant did not necessarily ruin teenage girls' ability to continue their education. One of his students, in fact, had fallen pregnant in Grade 11. She was able to give the baby to her parents to look after in Ermera while she finished secondary school in Dili and then continued to university. Studying away from home in the capital was a way to avoid the negative stigma that she would have faced had she continued her study in Ermera, as nobody in Dili knew that she'd had a child. She was set to graduate in 2019. Mr Felix believed it depended from person to person: 'Some have a baby and don't want to continue. Others say that their baby can be looked after by their parents so that they can continue their study.' (Interview, 25/8/2019)

As covered in Chapter Five, a teacher and NGO staff member has pointed to the pressure which can fall on teenage girls who got pregnant and the irreversable damage that it can do to their prospects and their happiness (Interview, 30/3/2019, Wellington).

Amo Deonildo has acknowledged that society in Ermera is paternalistic: on some levels men have more opportunities, including opportunities to make decisions. While there are now equal numbers of boys and girls enrolled in schools, is clear that the combination of these factors - a paternalistic society, in which violence is widely accepted, and boys are solely learning about sex through pornography - have an adverse effect on students' education, on respectful relationships between teenagers, and pose a real threat to the opportunities, freedom, safety, health and happiness of teenage girls (Interview, 4/9/2019, Ermera vila). 


\section{Appendix 7: Additional tables}

\section{DETAIL ON STUDENTS' FUTURE PLANS AND ASPIRATIONS}

Table: Surveyed Grade 12 students' goals after finishing school (Detailed)

\begin{tabular}{|c|c|}
\hline Goal & Number of students \\
\hline $\begin{array}{l}\text { Go to university } \\
\text { 'Prepare myself for university' } \\
\text { 'Work to earn money to go to university' }\end{array}$ & $\begin{array}{l}76 \\
1 \\
2\end{array}$ \\
\hline $\begin{array}{l}\text { Answers with more detail: } \\
\text { UNTL } \\
\text { DIT } \\
\text { UNPAZ } \\
\text { ICS } \\
\text { Indonesia - } \\
\text { Study in the Medicine/Nursing Department at UNTL }\end{array}$ & $\begin{array}{l}5 \\
1 \\
1 \\
1 \\
1 \\
1\end{array}$ \\
\hline $\begin{array}{l}\text { Take a course } \\
\text { Take an English course } \\
\text { Take English and computing courses } \\
\text { Take English etc. courses } \\
\text { Take some courses }\end{array}$ & $\begin{array}{l}25 \\
7 \\
1 \\
1 \\
1\end{array}$ \\
\hline $\begin{array}{l}\text { Plan involves study at university or at a course } \\
\text { Take a course OR go to university } \\
\text { Go to university, and at same time take an English course } \\
\text { Go to university, or if I fail, attend a course }\end{array}$ & $\begin{array}{l}2 \\
1 \\
2\end{array}$ \\
\hline $\begin{array}{l}\text { Enter a seminary } \\
\text { 'To improve my future' } \\
\text { Enter a seminary and go to university }\end{array}$ & $\begin{array}{l}1 \\
1\end{array}$ \\
\hline $\begin{array}{l}\text { Professions } \\
\text { Join the F-FDTL } \\
\text { Join the 'Força BOP'68 } \\
\text { Become a journalist }\end{array}$ & $\begin{array}{l}1 \\
1 \\
1\end{array}$ \\
\hline Make a school garden & 2 \\
\hline
\end{tabular}

68 'Forsa Batallaun Orden Publiku' or 'Public Order Battalion' is an armed branch of PNTL, the national police force of Timor-Leste. 


\begin{tabular}{|l|l|}
\hline $\begin{array}{l}\text { 'I want to learn better at secondary school for an even better } \\
\text { future'69 }\end{array}$ & 2 \\
\hline 'I want to do something good after finishing school'70 & 2 \\
\hline 'I want to do something good before finishing school’1 & 1 \\
\hline Unclear response: 'I want continue to a survey"72 & 1 \\
\hline
\end{tabular}

Table: What interviewed teenage students want to do in the future

\begin{tabular}{|c|c|c|}
\hline Participant & Future plans and aspirations & $\begin{array}{l}\text { Favourite school } \\
\text { subjects }\end{array}$ \\
\hline $1-18, F$ & $\begin{array}{l}\text { Become a journalist, join the police force or the Defence } \\
\text { Force (F-FDTL), or become a professional footballer. } \\
\text { Move to Dili, where her brothers and sisters lived. }\end{array}$ & English \\
\hline $2-18, F$ & $\begin{array}{l}\text { Study English at UNTL and become an English teacher; } \\
\text { work and live with her family, earn some money, and } \\
\text { perhaps buy a motor and go on trips with family } \\
\text { members during holidays. }\end{array}$ & $\begin{array}{l}\text { English, } \\
\text { Portuguese }\end{array}$ \\
\hline $3-16, F$ & $\begin{array}{l}\text { Attend university at UNTL, study Journalism and } \\
\text { become a journalist. At the same time become an artist. }\end{array}$ & $\begin{array}{l}\text { Biology, Physics, } \\
\text { Chemistry, English }\end{array}$ \\
\hline 4 - & $\begin{array}{l}\text { Get a high score in the national exams, get into UNTL } \\
\text { and study Geology and Medicine, and become a doctor. }\end{array}$ & English, Geology \\
\hline $5-18, F$ & $\begin{array}{l}\text { Her father wants her to become a nun but she wants to } \\
\text { do something different, like becoming an English } \\
\text { teacher. }\end{array}$ & Biology \\
\hline $6-18, M$ & $\begin{array}{l}\text { Study philosophy and English at university and become } \\
\text { an English teacher }\end{array}$ & Biology, English \\
\hline $7-16, F$ & $\begin{array}{l}\text { Attend university at UNTL, study Medicine and become } \\
\text { a nurse in order to be able to work in health clinics and } \\
\text { help people in bad health. }\end{array}$ & $\begin{array}{l}\text { English, } \\
\text { Mathematics }\end{array}$ \\
\hline $8-18, M$ & Attend university at UNTL and study either Medicine or & English, Biology \\
\hline
\end{tabular}

\footnotetext{
${ }^{69}$ Tetun: Hau hakarak apreende diak liu iha sekundaria atu nune futuru oin mai diak liu tan.

${ }^{70}$ Tetun: (1) Hau hakarak halo buat ruma diak iha eskola depois de remate; (2) hau remate segundario hau halo buat ruma nee diak.

${ }^{71}$ Tetun: W hakarak halo bu'at ne'ebe diak antes remata eskola w tenke hetan susesu ba w nia futuru.

${ }^{72}$ Tetun: Hau remata iha eskola sekundariu hau hakara ba kontinua iha ba survei.
} 


\begin{tabular}{|c|c|c|}
\hline & $\begin{array}{l}\text { Petroleum, and either become a doctor or a director in } \\
\text { a company in the petroleum sector. }\end{array}$ & \\
\hline $9-18, M$ & $\begin{array}{l}\text { Become a doctor in order to help to support his family, } \\
\text { including his younger siblings. Work in Dili to earn the } \\
\text { money to pay for university if his parents are unable to } \\
\text { pay his tuition. After becoming a doctor he will work } \\
\text { wherever the government places him. }\end{array}$ & $\begin{array}{l}\text { English, } \\
\text { Portuguese }\end{array}$ \\
\hline $10-17, M$ & $\begin{array}{l}\text { Continue his studies at senior secondary level, then go } \\
\text { to university and become a journalist. }\end{array}$ & $\begin{array}{l}\text { English, } \\
\text { Portuguese, } \\
\text { Mathematics, } \\
\text { Biology }\end{array}$ \\
\hline $11-18, M$ & $\begin{array}{l}\text { Go to university, study Biology and become a Biology } \\
\text { teacher in Ermera vila or in Ponilala. (This student is } \\
\text { now studying Medicine at UNTL.) }\end{array}$ & Biology, English \\
\hline
\end{tabular}

\section{DETAIL ON SKILLS IDENTIFIED BY INTERVIEWED STUDENTS}

Table: the skills identified by teenage interview participants as most useful to them

\begin{tabular}{|l|l|l|}
\hline Student & Skill identified & Future plans and goals \\
\hline $18, \mathrm{~F}$ & $\begin{array}{l}\text { Life skills: how to live alone as a single child } \\
\text { (moris mesak), raised by her grandparents; how } \\
\text { to live with the family of a relative while going } \\
\text { to school, and to love them and receive their } \\
\text { hospitality. }\end{array}$ & $\begin{array}{l}\text { Go to university and become } \\
\text { an English teacher. }\end{array}$ \\
\hline $16, \mathrm{~F}$ & $\begin{array}{l}\text { Debating; learning some English; organising } \\
\text { skills. (This student, with other teenagers, } \\
\text { organised a meeting in her community about } \\
\text { the best way to develop their postu (subdistrict } \\
\text { town). }\end{array}$ & $\begin{array}{l}\text { Go to university and, if she } \\
\text { had time and money, a } \\
\text { musician. }\end{array}$ \\
\hline $18, \mathrm{~F}$ & $\begin{array}{l}\text { Public speaking (mentalidade koalia iha oin); } \\
\text { self-confidence, and how to be a good student. }\end{array}$ & $\begin{array}{l}\text { Go to university, study } \\
\text { Geology and Medicine, and } \\
\text { become a doctor. }\end{array}$ \\
\hline
\end{tabular}




\begin{tabular}{|c|c|c|}
\hline $18 ? \mathrm{~F}$ & $\begin{array}{l}\text { Public speaking, which was useful when } \\
\text { foreigners came to visit the school; speaking a } \\
\text { little English; being able to do assignments. }\end{array}$ & $\begin{array}{l}\text { Her father wanted her to } \\
\text { become a nun, but she } \\
\text { wanted to do something else } \\
\text { such as teaching English. }\end{array}$ \\
\hline $18, M$ & $\begin{array}{l}\text { The ability to apply the capacities and abilities } \\
\text { he learned in school within his society. Public } \\
\text { speaking and conflict resolution skills from a } \\
\text { leadership course; learning some English from } \\
\text { the free course. }\end{array}$ & $\begin{array}{l}\text { Study Biology and English at } \\
\text { university and become a } \\
\text { teacher. }\end{array}$ \\
\hline $16, F$ & $\begin{array}{l}\text { The ability to help friends (classmates) to } \\
\text { formulate responses to questions during group } \\
\text { discussions. I.e. interpersonal skills, } \\
\text { communication skills and the ability to work } \\
\text { within a group. }\end{array}$ & $\begin{array}{l}\text { Study Medicine at university } \\
\text { and become a nurse. }\end{array}$ \\
\hline $18, M$ & $\begin{array}{l}\text { Explaining how to do things (such as } \\
\text { homework) to others; conflict resolution skills. } \\
\text { This student also identified actions of charity } \\
\text { (asaun karidade) which were a school activity at } \\
\text { Imacon School as a significant experience. }\end{array}$ & $\begin{array}{l}\text { Study medicine or petroleum } \\
\text { at university and either } \\
\text { become a doctor or a } \\
\text { manager in the petroleum } \\
\text { sector. }\end{array}$ \\
\hline $\begin{array}{l}18(?), \\
M .\end{array}$ & $\begin{array}{l}\text { The ability to teach fellow classmates (kolega) } \\
\text { or younger students, for example at the English } \\
\text { course in Ponilala. At home, working as part of } \\
\text { a group in order to help his parents. }\end{array}$ & $\begin{array}{l}\text { Go to university and become } \\
\text { a doctor. }\end{array}$ \\
\hline 17, M. & $\begin{array}{l}\text { Public speaking (mentalidade atu koalia iha } \\
\text { ema barak nia oin), for instance at school } \\
\text { assembly, or when answering a question in } \\
\text { class. }\end{array}$ & Become a journalist. \\
\hline $18, M$ & $\begin{array}{l}\text { Public speaking; the ability to learn } \\
\text { independently (aprende mesak). }\end{array}$ & $\begin{array}{l}\text { Go to university and become } \\
\text { a Biology teacher, although } \\
\text { he is now enrolled in } \\
\text { Medicine at UNTL. }\end{array}$ \\
\hline
\end{tabular}


$18, F$ ? One student could not identify one or more skills they viewed as useful to them.

\section{DETAIL ON PARENT LIVELIHOODS}

Table: Parent livelihoods of interviewed teenage students

\begin{tabular}{|c|c|}
\hline Participant & Parents' professions \\
\hline 1 & Parent already interviewed \\
\hline 2 & Parent already interviewed \\
\hline 3 & $\begin{array}{l}\text { Father: carpenter } \\
\text { Mother: housewife }\end{array}$ \\
\hline 4 & $\begin{array}{l}\text { Mother works in Dili as a public servant in an agricultural office. } \\
\text { Elder brother helps to support this student and his siblings by } \\
\text { working as a farmer. Father has passed away. }\end{array}$ \\
\hline 5 & $\begin{array}{l}\text { Parents work as farmers, harvest coffee, run a kiosk and raise } \\
\text { animals. }\end{array}$ \\
\hline 6 & $\begin{array}{l}\text { Mother is a housewife and works in the church. Father is a } \\
\text { farmer. }\end{array}$ \\
\hline 7 & Parent already interviewed \\
\hline 8 & Parent already interviewed \\
\hline 9 & $\begin{array}{l}\text { Mother is a housewife and farmer, Father works as a driver for a } \\
\text { private company in Dili. }\end{array}$ \\
\hline 10 & $\begin{array}{l}\text { Brought up by grandparents, who are farmers, harvest coffee } \\
\text { and raise animals. }\end{array}$ \\
\hline 11 & $\begin{array}{l}\text { Mother infrequently works as a farmer, harvests coffee and } \\
\text { raises animals (pigs, cows, horses, chickens, goats). Father is a } \\
\text { teacher, and receives a veteran salary. }\end{array}$ \\
\hline
\end{tabular}




\section{Appendix 8: Original passages of quoted interviews}

[1] Interview with Amo Deonildo: 'Premeira parte kultura nee diak, ida ami nia identidade ... iha Ermera ami nia problema mak halo lia, lia moris, lia mate'.

[2] Interview with Amo Deonildo: 'Uza osan abiru'.

[3] Student surveys: 'hau nia inan serbisu iha uma [deit]', or 'hau nia ama serbisu iha uma [deit]'.

[4] The xefi suku of Mirtutu: 'Iha-nee, ema laiha matenek, tenke husu familia ajuda malu. Familia mak laran ... Karik iha Australia, Amerika, depois eskola iha matenek no hetan serbisu, Timor la iha.'

[5] The xefi suku of Mirtutu: 'juventude lakohi serbisu toos'.

[6] Interview with a teenage student: "Importante tebes hodi aumenta ami nia kapasidade, oinsa koalia, oinsa halo 'public speaking' ba iha sosiedade sira, buat neebe ladiak iha sosiedade hau tenki ser tuun ho hau tenki ser fo hanoin ba sira, hau ida-nee la diak, tenki ser halo diak hodi dezenvolve ita-nia rain."

[7] Interview with a parent: 'La hetan serbisu, nee la diak ... Hakarak oan sira ba matenek ba futuru Timor nian nee ba oin.'

[8] Interview with Amo Deonildo: 'That's the challenge for us right now. With the development of mind, way of life, exchanging culture with others, also impacts our social life in Ermera. I think we have to explain to the students to be proud as Timorese, and as [residents of] Ermera. Know each other, respect each other. It will be a good way for them. And we also have to be open minded, we also have to face the difference, development, we have to face it in life.' 
[9] Interview with Director-General Antoninho Pires: '...Depois eskola tenki hetan matenek, tenki hetan skill, para depois bele dezenvolve ninia an, no mos dezenvolve nia familia, no mos bele kontribui ba dezenvolve estadu. Nee maka Ministeriu Edukasaun nia knaar...'

[10] Full address: 'Graduate, ba inan aman sira, ba familia tomak, husu deit ba imi neebe foin gradua ona, labele hanoin katak konhesimentu neebe imi hetan nee mak nee ona. Lae. Loke. Sei loke nafatin, nee ba oin nafatin. Hau mos ezije ba imi, prapara an nafatin ba liuliu konaba dezenvolve imi nia abilidade neebe se mos rendima karik dizimos no tenki esforsu an atu harii ... ida neebe imi sei hakiak, tenki hakiak no fahe ba sosiedade tomak, ba ita-nia povu. Imi, jerasaun foun... sei sai - sai saida? (crowd shouts a response) "na'in ba dezenvolvimentu"! Imi mak sei dudu, rai doben nee ba oin. Tuir dalan modernisasaun, neebe sei hetan nia pase husi progresu ekonomiku no sosial.' (GMN, 2020d)

[11] Interview with a teenage student: 'Esperensia iha eskola sekundariu mak hanesan fatin neebe atuita aprende liu tan saida mak ita aprende tiha ona iha ensinu pre-sekundaria, no iha sekundaria hanesan estudante aprende kona ba oinsa hatene koalia, oinsa hatene konaba halo mental ninian, no buat neebe importante liu maka aprende konaba siensia ninian.'

[12] Interview with a teenage student: 'Duni nee joven sira ba eskola besik, i eskola mos la bele selu karun, inan aman balu neebe iha ekonomia neebe laduun bele suporta sira-nia oan ba eskola.'

[13] Interview with a teenage student: 'Hau hakarak ba eskola universidade, maibee, hau ser pergunta ser tau .. iha buat barak loos neebe hau hakarak hili neebe, hakarak .. tenki hili ida deit sai hanesan ... buat neebe tenki estuda, maibee hau nia apa hakarak hau ba madre (laughs), maibee, seidauk hatene.'

[14] Interview with a parent: 'Edukasaun sekundariu importante ba aumenta matenek. Importante mak remata eskola.' 
[15] Interview with a parent: 'Edukasaun sekundariu he'e importante tebes. Importante tebes ba oan sira iha futuru... Edukasaun sekundariu mak determina oan sira nia estudu iha nivel superior hodi atinji ba oan sira nia futuru.'

[16] Interview with a parent: 'So eskola mak dalan diak ba hetan moris diak ... hau hakarak nia [labarik nia] moris diak ho edukasaun ... buat ne'ebe nia hakarak hau tuir deit'.

[17] Interview with a parent, the xefi aldeia: 'Hau hanoin edukasaun mai ami jerasaun tuan ambila katak ida nee tau prioridade, ida nee bele kontinuasaun tanba, edukasaun nee maka futuru nasaun ninian, se laiha edukasaun, nasaun sira ba o. Ida nee maka ami nuudar orantua ami hakarak nee mak labarik sira nee hakarak, lakohi, tenki eskola.' Note: 'ambila' and 'orantua' are Indonesian, meaning 'take' and 'parent'.

[18] Interview with the same parent: 'Ami bele dehan katak edukasaun sai importante, xave importante nasaun ida nian. Se la iha edukasaun, ami bele dehan katak oinsa hau hatete, se la iha edukasaun, nasaun sai oinsa halo. Nee maka ami nuudar agrikultur, ami bele buka osan, hakarak lakohi ami nia oan sira nee, hakarak lakohi tenki ba edukasaun, edukasaun mak sai importante, xave nasaun ninian mak edukasaun.'

[19] Interview with the same parent: 'Ami bele dehan katak ami nia oan sira nee halo buka ba eskola, las atu gos buka serbisu, halakon deit sira-nia kbiit, nunee, aban-bainrua maromak mak determina, sira hakarak bele entaun, maromak bele dehan ... sira bele hetan ... dehan katak, buat hotu-hotu husi maromak, po maimuk sira serbisu mai ami nuudar uitoan ami agradese, laiha serbisu mos ami agredese nafatin tanba ami nia oan sira nee bele hetan edukasaun.'

[20] Interview with a parent: 'Hanoin oan ba sekundariu nee, atu sae ema ne'ebe matenek, hodi aban sira bele ba universidade.'

[21] Interview with the same parent: 'Edukasaun importante tanba hodi konhesensia ba mundu ... Konhesensia hatene hadomi ema seluk. Ida nee maka edukasaun importante liu. 
Konhese [kona] ba mundu tanba konhese ema seluk. Hatene hadomi ema seluk, hanesan mos ema seluk hadomi ami. Ida nee mak hodi ba eskola.

[22] Interview with a teenage student: 'Sin, iha Ponilala iha foin sae barak mak la eskola tanba problema ekonomia iha familia. ... Iha barak halimar iha uma deit, balun ba tuir, hanesan halo toos sira nee, atu ajuda fali inan aman. Maibee iha familia balun iha ekonomia neebe iha, maibee lakohi dudu sira nia oan atu ba eskola.'

[23] Interview with a teenage student: 'Sira tauk... sira tauk sala.' 